\title{
Obstetric fistula: Can community midwives make a difference? Findings from four districts in Kenya
}

Charlotte E. Warren

Population Council

Annie Mwangi

Population Council

Follow this and additional works at: https://knowledgecommons.popcouncil.org/departments_sbsr-rh

Part of the Demography, Population, and Ecology Commons, Family, Life Course, and Society Commons, International Public Health Commons, Maternal and Child Health Commons, and the Women's Health Commons How does access to this work benefit you? Let us know!

\section{Recommended Citation}

Warren, Charlotte E. and Annie Mwangi. 2008. "Obstetric fistula: Can community midwives make a difference? Findings from four districts in Kenya." Nairobi: Population Council. 



\section{Obstetric Fistula: \\ Can Community Midwives Make a Difference?}

Findings from four districts in Kenya

by

Charlotte Warren and Annie Mwangi

December 2008 


\section{ACKNOWLEDGMENTS}

We would like to thank all those who made this study possible. Work of this nature would not have been achievable without full support from the Ministry of Health, Division of Reproductive Health, Dr Josephine Kibaru and Alice Mwangangi. In addition we acknowledge the support from the PMOs from Central, Eastern and Coast Provinces and the District Reproductive Health Coordinators of Kilifi, Mwingi, Nyandarua and Taita Taveta.

Thanks go to Erick Oweya and Douglas Waswa who coordinated the data collection and analysis. Our appreciation goes to the research assistants that formed field teams to collect data within the communities.

Special thanks go to all the women who participated in the study; without them the research would not have been possible.

We would also like to recognize the financial support from UNFPA. 


\section{SUMMARY}

Despite health sector efforts to improve skilled attendance at delivery in Kenya, health facility deliveries remained static between the two demographic health surveys of 1998 and 2003. This stagnation of health facility deliveries may be attributable to intangible cultural factors where the patterns of care-seeking behaviour cannot purely be explained by access or awareness barriers. Behaviour and decision-making are motivated by multiple variables that operate within the localized understandings of health and illness (Rumbold and Warren 2006).

Poor care seeking behaviour around childbirth can result in women experiencing prolonged and/or obstructed labour. If this is not managed appropriately it can lead to obstetric fistula. Fistula occurs when there is damage to tissues in the pelvic region and a fistula or opening forms between a woman's vagina and bladder or rectum, leaving her with chronic incontinence. In most cases, the baby dies. Women with obstetric fistula are living evidence of a failed maternal health care system. Although obstetric fistula has been virtually eliminated in developed countries by improved and universally accessible obstetric care, fistula is widespread in subSaharan Africa.

In an effort to reduce the high number of births attended by unskilled assistants, the Division of Reproductive Health (DRH), Population Council and Nursing Council of Kenya developed the Community Midwifery Approach in 2005. Subsequently as part of the UNFPA Global Campaign to End Obstetric Fistula, DRH and UNFPA built on the Community Midwifery Approach to develop a comprehensive community midwifery intervention strategy that aimed at increasing skilled attendants at birth and prevention of obstetric fistula. In 2006, DRH, with technical and financial support from UNFPA, piloted the comprehensive community midwifery initiatives in two Districts of Nyandarua and Mwingi and later in two other districts of TaitaTaveta and Kilifi, thus making 24 districts in Kenya with Community Midwifery programmes on the ground by 2008 .

The Kenya community midwives (CM) complement the efforts carried out in health facilities to increase skilled attendance at birth. A working community midwife has successfully completed competency based updates/skills training, has been certified by the DRH and licensed by the nursing council to provide these services in the community. The CM can be a retired or out of work health professional or a midwife running a small private clinic, with evidence of a formal qualification in obstetric skills and permanent residency within the community to be served. The $\mathrm{CM}$ links with the health care system through the nearest health facility for support. She also links with the civil society, administration and community leaders and groups to work as team in the advocacy of maternal and newborn care services as well as work closely with other community health providers recognizing the role of each in the provision of $\mathrm{MNH}$ in the community.

In 2003, UNFPA spearheaded a global Campaign to End Fistula which raises awareness of the issue, conducts needs assessments, and expands services for prevention and treatment. UNFPA is working in 35 countries to prevent and treat obstetric fistula (OF) and to help rehabilitate and empower women after treatment. In 2003 UNFPA carried out facility based assessments in nine countries in Africa.

In 2003, UNFPA funded the first baseline survey on obstetric fistula in Kenya. The survey estimated that there are 3,000 new cases per year, with approximately one to two fistulas occurring per 1,000 deliveries. The backlog of cases is estimated at 300,000. Only 7.5 percent of women with fistula are able to access treatment (UNFPA 2004). A hospital-based study 
conducted in the West Pokot region of Kenya (Mabeya 2004), found the mean age of women with fistula was 20.5 years, ranging from 14 to 38 years. The main cause was obstructed labour.

Until recently there were few gynecologists (mainly funded by Amref) in Kenya who had expertise in obstetric fistula repair in the country and patients treated were not effectively rehabilitated. Although the potential for repair of fistula exists at district hospitals, OF repair is not always done routinely. However, UNFPA has been supporting the scale up of training of health care providers in the management/repair of obstetric fistula in more hospitals across the country. Only in the latter part of this decade has there been hope of repair for women living with OF.

This report seeks to understand the experiences of women affected by fistula and whether community midwives can contribute to preventing obstetric fistula in rural settings in Kenya.

\section{Methodology}

Both quantitative and qualitative methods of data collection were used during May 2008 in four UNFPA supported districts: Nyandarua, Mwingi, Kilifi and Taita Taveta. Professional midwives with counseling skills and trained in data collection administered structured questionnaires to samples of women living with obstetric fistula/fistula repaired (82) as well as women who had experienced obstructed labour (70) and were willing and able to talk about their experiences. The researchers also interviewed community midwives (56) to assess the extent of CM practice and challenges faced in providing maternal and newborn services in the four districts. Hospital records for women who experienced obstructed labour were also reviewed (51) and the capacity of the district hospitals to carry out fistula repairs assessed (7). Four social scientists facilitated four focus group discussions with men and women in the four districts to determine their perceptions around maternal health and community midwifery.

\section{Findings}

A number of issues emerged from the study and the three case studies describing women's experiences of living with obstetric fistula are indicative of the many women interviewed: women can suffer obstructed labour and subsequent fistula during any pregnancy; knowledge on maternal health and care seeking behavior remain unchanged in some areas since the 1960s with community members continuing to seek alternative remedies; cultural influences and male dominance continue to hinder women from seeking health care; lack of money prevents women from seeking timely care. However it is now more widely known that OF can be successfully repaired and women can continue with a healthy life after repair.

This study has confirmed other findings that: women who develop fistula and their husbands are less likely to have been to school (almost half of the women interviewed could not read in either English or Kiswahili and third of their husbands had never been to school), and more likely to live in poverty. Forty one percent of women interviewed earned less than Kshs 2000 (\$25) per month.

Women living with or have lived with fistula are less likely to have had help from a skilled midwife during delivery. For example this study found that 87 percent of women interviewed who developed fistula while having their fourth child were assisted by an unskilled attendant (relative/traditional birth attendant). Tragically, women with fistula are more likely to have a still birth. Study results show that only a quarter of women who developed obstetric fistula during their first birth had a live baby.

Once the fistula developed the majority of women did seek professional care and more than two-thirds have now been repaired. Just under half (47\%) were operated on once, 32 percent 
operated on twice and 21 percent operated on 3 to 5 times. Sixty-one percent had repair for vesico-vaginal fistula (VVF) and 12 percent repair for vesico and recto-vaginal fistula (RVF). Some of challenges include limited opportunities for follow-up and funds to support women's rehabilitation back into society.

Seventy percent of the women had fistula treatment and care carried out in the last two years. Only 19 percent were carried out more than five years ago. This indicates the success of active campaigns and awareness creation of fistula in Kenya in recent years.

Community knowledge: The response to a complication during labour and childbirth depends on the perceived severity and cause, and may lead to inappropriate or delayed treatment.

Community perceptions of the causes of obstructed labour are varied and often incorrect. Some men felt that obstructed labour was due to lack of exercise and unwillingness of women to do housework during pregnancy. Others believe it is brought on by overwork such as too much digging and bending in late pregnancy; or it is due to witchcraft and believe the woman has been looked at with bad eyes. Some community members think that a woman who did not really want to be pregnant will suffer from prolonged/obstructed labour.

Nevertheless, a number of community members knew that if "the child is too big" then problems during delivery are likely to occur. They were also aware that it seems to happen more frequently in young girls. Men in all four districts indicated that if women did not attend ANC and did not seek professional care during labour and childbirth, obstructed labour was more likely to happen. Men and women in FGDs in all four districts said that women with obstructed labour become very weak and require an operation to deliver the baby.

Community midwives' knowledge while good requires further updating specifically on obstructed labour. In practice however it was encouraging to note that $100 \%$ of the women managed by the community midwives with a diagnosis of obstructed labour were promptly referred and none developed a fistula. Issues emerging from community midwife case histories demonstrate that women experiencing complications in labor are not referred to the CMs in time. However the CMs are able to stabilize the clients prior to referral with intravenous fluids and notify the hospital in advance. The majority of health providers in the facilities view the $\mathrm{CMs}$ in a positive note and have seen an increase in the number of women referred from the community with obstetric complications.

Quality of care in referral facilities requires improvement. A number of inpatient records in the district hospitals were reviewed to assess the quality of care provided to women in obstructed labour who underwent cesarean section. Blood for grouping and cross matching was taken in 76 percent of the cases but worryingly in only 37 percent of the cases were IV fluids commenced once diagnosis of obstructed labour was made. Only half of the case notes reviewed was a urinary catheter inserted prior to $\mathrm{C} / \mathrm{S}$. The outcome of the index pregnancies indicates challenges in ensuring quality of care during labour and delivery with 16 percent of the case notes reviewed resulting in death of the newborn. The capacity of the hospitals reviewed in the study districts needs to be strengthened. Some hospitals have trained staff and no equipment and vice versa.

\section{Challenges for Scaling up Community Midwifery}

The community midwifery strategy has demonstrated in both Western province and the four UNFPA districts that it is feasible, acceptable and effective in improving skilled attendance and reducing obstetric complications with specific emphasis on obstructed labour. The challenge is now consolidating and increasing the number of available CMs. However it is important that all 
CMs should receive the necessary seed equipment at the time they complete their training as well as refresher updates in management of maternal complications. While all CMs referred women in prolonged labour in time, gaps in knowledge do exist. However these gaps in knowledge are no different to gaps in knowledge among service providers working within health facilities. Updates for maternity staff are also necessary.

For the sustainability of CM initiative, and while the issue of payment of community health extension workers is under review the introduction of a two day business skills workshop goes a long way to support the CM provide her essential services and increase sustainability (Mwangi and Warren 2008).

\section{Recommendations}

The Ministry of Public Health and Sanitation and the Ministry of Medical Services have identified MNH as a priority. In line with the strategies outlined in the Kenya MNH road map for the acceleration in the reduction of maternal and newborn morbidity and mortality (draft 2008) and other national policy documents these recommendations are focused at preventing obstetric fistula and scaling up treatment and care for women living with OF. A particular emphasis is on districts where skilled attendant rates are low and poor health seeking behaviour for obstetric complications. In summary the key recommendations emerging from this report are: to update health facility midwives in MNH skills including prevention, treatment and care of obstetric fistula; train more community midwives; increase community awareness; listen to men and women and involve them in community health committees and district health plans for improving MNH taking into account cultural sensitivities.

Detailed activities regarding the recommendations are outlined at four different levels: the community, the linkages between community and health services, the health facility and the policy level. These should be reviewed and incorporated into annual operational plans:

\section{Home, family and community level}

- Encourage women and families to make birth plans, educate on pregnancy and childbirth related problems and encourage them to seek care early for obstetric complications

- Instigate financial literacy activities including saving mechanisms and income generating schemes: encourage families to enroll in health insurance schemes such as NHIF, KWFT, Equity bank, Faulu, K-rep etc. Scale up OBA/DSF according to GOK guidelines.

- Through the CMs, Community Health Committees and barazas (community meetings) develop specific messages for obstetric complications and OF in local language and use multi-channel distribution; address cultural practices that negatively impact on maternal and newborn health

- Encourage fistula survivors to be advocates at community level

- Develop advocacy messages with community about risks of pregnancy and childbirth

- Expand the number of community midwives and their mandate

- Encourage male involvement in birth planning and emergency preparedness (e.g., decisions, fees, transport, and identification of a birth companion). Encourage open discussions about maternal health between men and women so it is no longer 'just a woman's issue'

- Develop mechanisms for data collection at community level for all pregnant women and women with $\mathrm{OF}$ for easy follow-up and care 


\section{Linkages between community and health services}

- Strengthen referral system:

- Procure more ambulances / motorcycle ambulances;

- Ambulances should be distributed evenly across the districts in strategically placed health facilities, not all at district hospital. Drivers should be on call 24/7.

- Develop / strengthen district wide transport schemes: Agreement with private car owners/matatus (minibuses)

- Build more maternity waiting homes adjacent to hospitals where distances are great

- Regular supervision and incentives for CMs and community health workers

- Improve rehabilitation and reintegration of fistula clients, link to social support programs

\section{Quality of care in health facilities:}

- Strengthen maternity services at all levels:

- Ensure essential equipment, drugs and supplies

- Upgrading of existing facilities to provide quality maternity care and treatment and care for fistula nearer to where women live;

- Improve client waiting times

- Strengthen in-service and pre-service training, supervision and quality assurance

- Improve provider attitudes and moral

- Regular updates in essential obstetric care updates

- Emphasize prevention of OF, use partograph for every labour, use of indwelling catheters for prolonged/obstructed labour, close follow up.

- Adequate staffing and skills mix in health facilities and accountability of health providers

- Clinical audits and mortality audits for mothers, newborns and stillbirths

- Introduce use of intra-partum case fatality rate - which is defined as the 'proportion of deliveries that result in late stillbirths and early neonatal deaths' in a given health facility

- To address the backlog of women living with fistula:

- Train more fistula teams (nurses, doctors theatre staff, physiotherapists and social workers) at district level: all medical officers/gynecologists should be able to provide treatment and care for fistula

- Disseminate evidence based guidelines/standards at local levels

- Ensure sufficient equipment is available where staffing for treatment and care exists

- Following treatment and care efforts continue to rehabilitate and re-integrate women back into their communities

\section{Policy level}

- Output based financing: subsidize maternal health care services and RH commodities; consider free $\mathrm{C} / \mathrm{S}$ for obstetric emergencies and $\mathrm{OF}$ treatment and care (voucher based reimbursement). MOPHS and MOMS are currently reviewing OBA/DSF to target poor women

- Lobby Parliamentarian Health Committee to raise awareness of OF at national level

- Review the use of motorcycle ambulances for referral : four motorcycles ambulances cost the equivalent as one land cruiser ambulance

- In implementing the Community Strategy, design effective training packages for all community health workers (including TBAs) with clear roles and responsibilities; provide on-going supervision and refresher training for providers in the community. 


\section{ACRONYMS AND ABBREVIATIONS}

$\begin{array}{ll}\text { ANC } & \text { Antenatal care } \\ \text { CEOC } & \text { Comprehensive Essential Obstetric Care } \\ \text { CM } & \text { Community midwife } \\ \text { C/S } & \text { Cesarean Section } \\ \text { DRH } & \text { Division of Reproductive Health } \\ \text { IEC } & \text { Information Education and Communication } \\ \text { IV } & \text { Intravenous } \\ \text { MDG } & \text { Millennium Development Goal } \\ \text { FBO } & \text { Faith Based Organisation } \\ \text { FGD } & \text { Focus Group Discussion } \\ \text { FP } & \text { Family Planning } \\ \text { OF } & \text { Obstetric fistula } \\ \text { OL } & \text { Obstructed Labour } \\ \text { LAM } & \text { Lactational Amenorrhoea Method } \\ \text { PGH } & \text { Provincial General Hospital } \\ \text { UNFPA } & \text { United Nations Population Fund } \\ \text { MNH } & \text { Maternal and Newborn Health } \\ \text { TBA } & \text { Traditional Birth Attendant } \\ \text { VVF } & \text { Vesico vaginal fistula } \\ \text { RVF } & \text { Recto - vaginal fistula } \\ \text { WHO } & \text { World Health Organisation } \\ \end{array}$




\section{CONTENTS}

Acknowledgments

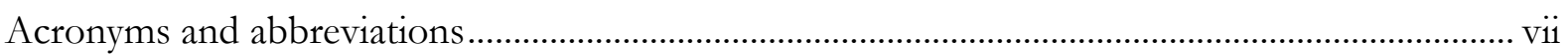

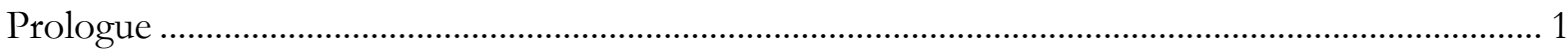

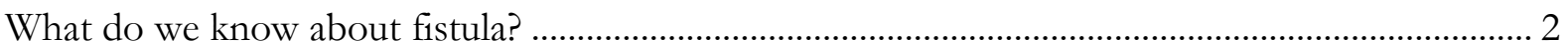

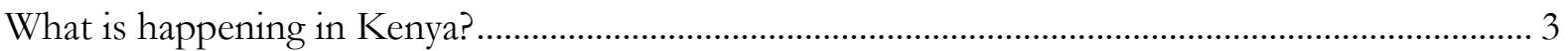

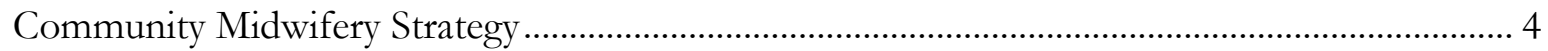

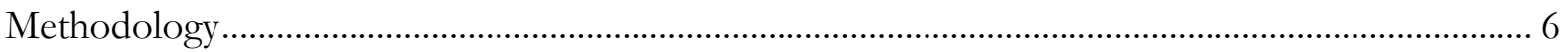

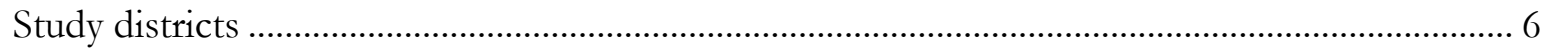

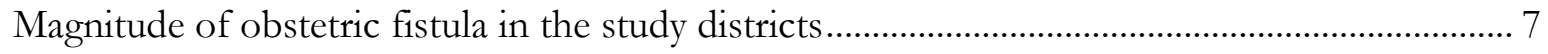

Characteristics of women living with obstetric fistula or who have experienced obstructed

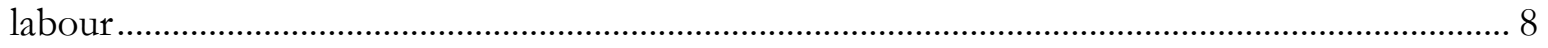

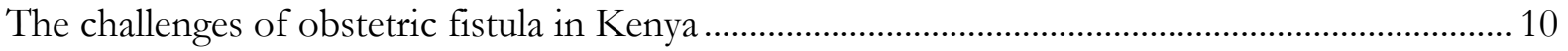

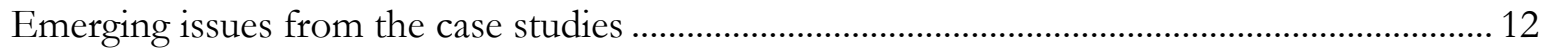

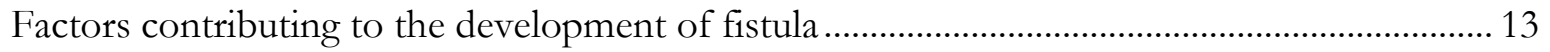

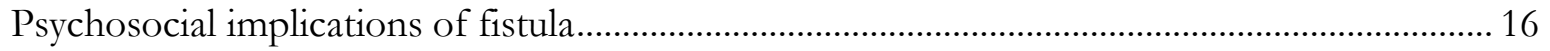

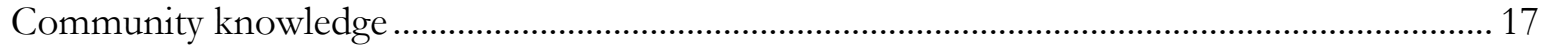

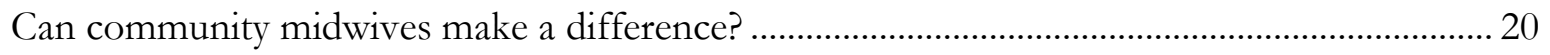

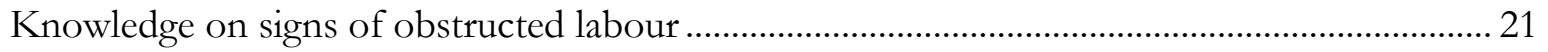

Community midwives can successfully manage obstructed labour.............................................. 22

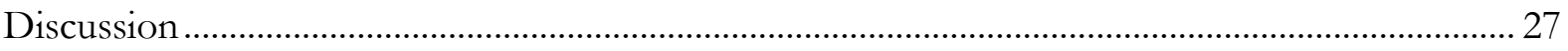

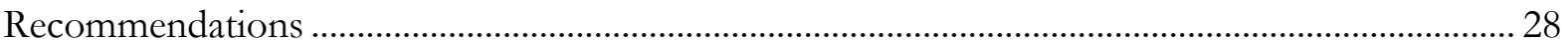

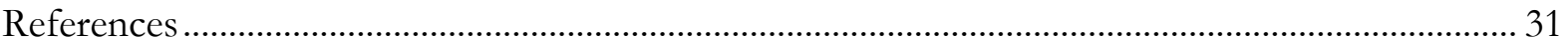

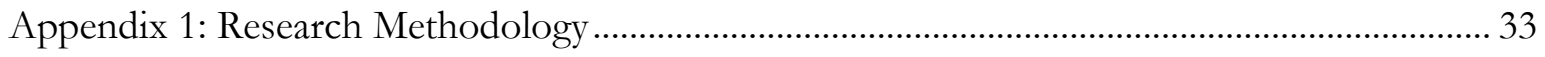

Appendix 2: Comparison of general characteristics of women by District and OF status ....... 37

Appendix 3: Literature Review of Obstetric Fistula ..................................................................... 41

Appendix 4: Hospital capacity/preparedness to repair obstetric fistula in the four districts .... 54 


\section{Prologue}

To help ensure safer deliveries, countries with high proportions of deliveries with unskilled attendants need to develop locally applicable and culturally acceptable strategies to improve care for women during pregnancy and childbirth for women by taking midwifery skills to their own homes. The percentage of deliveries with a health professional is one of the targets to measure achievement of the international Millennium Development Goal (MDG) for maternal health. Countries that have made a deliberate effort to provide skilled care at childbirth, with midwives based within the community backed up by a functional referral system, have improved maternal and newborn survival. Analysis of demographic health surveys in developing countries have shown a clear negative correlation between the proportion of deliveries attended by a skilled midwife and the maternal mortality ratio (Lerberghe and De Brouwere 2001, Manandhar et al 2003, WHO 2005). Skilled attendance during labour, delivery and the early post-partum period could reduce an estimated 16 to 33 per cent of deaths due to obstructed labour, haemorrhage, sepsis and eclampsia (Graham et al 2001).

Despite the health sector's efforts to improve skilled attendance at delivery in Kenya, health facility deliveries remained static between the two demographic health surveys of 1998 and 2003. This stagnation of health facility deliveries may be attributable to intangible cultural factors where the patterns of care-seeking behaviour cannot purely be explained by access or awareness barriers. Behaviour and decision-making are motivated by multiple variables that operate within the localized understandings of health and illness (Rumbold and Warren 2006).

Poor care seeking behaviour around childbirth can result in women experiencing prolonged and/or obstructed labour which is estimated to occur in approximately four to six percent of pregnancies and causes eight percent of maternal deaths globally (Donnay and Ramsey 2006). If prolonged and/or obstructed labour is not managed appropriately it can lead to obstetric fistula. Fistula occurs when there is damage to tissues in the pelvic region and a fistula or hole forms between a woman's vagina and bladder (VVF) or rectum (RVF), leaving her with chronic incontinence. In most cases, the baby dies. Women with obstetric fistula are living evidence of a failed maternal health care system.

Although obstetric fistula has been virtually eliminated in developed countries by improved and universally accessible obstetric care, fistula is widespread in sub-Saharan Africa, south Asia and some Arab States. It affects more than 2 million girls and women worldwide, with an estimated 50,000 to 100,000 new cases annually. Obstetric fistula (OF) has devastating consequences for women and is one of the most neglected issues in reproductive health globally. The emotional and economic impacts of obstetric fistula are substantial for women and their families (Bangser 2006). Root causes include early childbearing, malnutrition and limited access to emergency obstetric care. A review of 29 countries showed that many adolescent girls and women living with fistula were young, living in rural areas and among women who delivered four or more children.

In settings where home delivery is common practice maternal morbidity and mortality can be reduced if the health system can provide skilled care with an established referral and supervisory links so pregnant women can receive timely emergency obstetric care when they need it (Khalil and Roudi-Fahimi 2004). In order to address this gap community midwives have demonstrated that they can provide professional care to women in their homes. Assisted by professionals and with a functional referral system the first and second delays of maternal care can be effectively addressed. Timely decision making (using the partograph) and timely referrals are key factors in preventing obstructed labour and thereby preventing obstetric fistula (Rumbold and Warren 2006, Mwangi and Warren 2008). 


\section{WHAT DO WE KNOW ABOUT FISTULA?}

In 2003, UNFPA spearheaded a global Campaign to End Fistula which raises awareness of the issue, conducts needs assessments, and expands services for prevention and treatment. UNFPA is working in 35 countries to prevent and treat fistula and to help rehabilitate and empower women after treatment. In 2003 UNFPA carried out facility-based assessments in nine countries in Africa. In Kenya, UNFPA commissioned a survey in 2003 to determine the prevalence of fistula in Kenya revealed that an estimated 300,000 women are living with fistula with approximately 3000 new cases occurring each year.

OF is more than a women's health problem; it typically affects the most marginalized members of society, that is poor illiterate girls and women most frequently aged between 13-20 years (UNFPA 2003) in areas where health care is not accessible. Many have been abandoned by their husbands or partners, forced out of their homes, ostracized by family and friends and even isolated by health workers. Women with fistula may suffer a range of medical consequences, including incontinence, bladder infections and genital ulcerations as many as one in five women may also suffer "foot drop" involving nerve damage to one or both legs that impairs the ability to walk (UNFPA/Engender Health 2003). Given the magnitude of the problem and pass of efforts to address OF, the unmet need for repair of OF has been estimated at 99\% (Ahmed, Genadry et al 2007).

A multidisciplinary approach is necessary to combat fistula effectively as the majority of cases can be repaired and many others prevented. While mass OF repair projects have been organized as 'fistula fortnights' in some countries such as Kenya and Nigeria to help to reduce the backlog of fistula cases, it is important to ensure ongoing repairs in more hospitals across the country. In the past there has been an over reliance in some countries on foreign visiting surgeons (Tanzania) and few hospitals have the capacity for carrying out OF repair.

There are three critical factors required to combat OF effectively: adequate long term funding, presence of a surgeon who is fistula champion along with enhanced local surgical repair capacity, and adequate operating time and support team, essential equipment and supplies (Wall 2007). MacDonald and Stanton (2007) recommend upgrading of facilities, implementation of quality improvement systems and the need to cover women's transport costs as distances are great and women have to travel far (Bangser 2007).

Ojengbede et al (2007) advocate for early repair of fistula within 3 months of it occurring; however there is still wide debate internationally on this issue. WHO recommends that more evidence is required from multiple sites before concluding on this. The use of spinal anesthesia for simple fistulas carried out in Northern Ghana (Lassey 2007) and Nigeria (Ojengbede et al 2007) demonstrates that fistula repairs can be carried out effectively in low cost settings. A high rate of closure at first repair (94\%) in Malawi (Chilopora and Rijken 2007) was demonstrated. Women operated on in Kenya within 3 months had slightly better surgical outcome $94 \%$ vs. $87 \%$ than later surgery (Raassen et al 2007). However many authors

Why women suffer from the consequences of obstructed labour needlessly

- Socio-economic and cultural factors rather than physical access play a role in under utilization of health care services

- Many girls and women living in rural areas do not utilize health services because of their limited decision making power and attitudes and misconceptions about pregnancy and childbirth

- Lack of birth preparedness and knowledge of danger signs

- Economic instability impedes transport and access to maternal health services

- Treatment for OF is limited

- Lack of access to EmOC 
report high success rates for surgical closure of fistula based on time of discharge with limited evaluation on urinary continence or subsequent quality of life (Creanga, Genardry et al 2007). In Malawi Chilopora and Rijken found stress incontinence in $16 \%$ of women immediately after repair and in $6 \%$ after 6 months (2007).

Prevention is the key to ending fistula. Making family planning available to all who want to use it would reduce maternal disability and death by at least 20 per cent. Complementing skilled attendance at all births and emergency obstetric care for all women who develop complications during delivery would make fistula as rare in resource-poor countries as it is in the developed world today. These interventions are part of UNFPA's overall strategy to make motherhood safer. Addressing social issues that contribute to the problem - such as early pregnancy, girls' education, poverty and women's empowerment - are important areas of intervention as well (UNFPA 2003).

There is however, still need for further action - success of any IEC campaign relies on intensive use of mass media along with interpersonal communication and community mobilization. Key considerations also include improving health services and access to health services for the poor and a review of the costs and affordability of services. In addition more needs to be done to bring about a culture that fosters the education and empowerment of women (Mohammed 2007) and delay in child bearing (Ahmed 2007).

Another challenge to reducing $\mathrm{OF}$ is that there is no solid population-based estimate of number of OF anywhere (Ahmed Holtz and Stanton 2007). Although Dolea and Abouzahr estimated the OF fistula rate of $0.08 \%$ of births as a proportion of neglected obstructed labour cases, others estimate using the prevalence of 1 or 2 OF cases per 1000 live births. Johnson estimated a crude fistula rate of 15.6\%/1000 live births for Malawi (Johnson 2007). UNFPA however funded questions to be added to the most recent Demographic Health Survey in Kenya in 2008.

Appendix 3 details a summary of literature reviewed on fistula.

\section{WHAT IS HAPPENING IN KENYA?}

In Kenya it is estimated that there are 3,000 new cases per year, with approximately one to two fistula per 1,000 deliveries. The backlog of cases is estimated at 300,000. Only 7.5\% of women with fistula are able to access treatment (UNFPA 2004). A hospital-based study conducted in the West Pokot region of Kenya (Mabeya 2004), found the mean age of women with fistula was 20.5 years, ranging from 14 to 38 years. The main cause was obstructed labour.

In 2004 the MOH and UNFPA commissioned a needs assessment of obstetric fistula in selected districts (Kwale District in Coast province, Mwingi in Eastern Province, West Pokot in Rift Valley Province and Homa Bay in Nyanza Province) in Kenya where fistula was suspected to be most prevalent. The assessment set out to establish the magnitude and contextual factors related to OF. Six hospitals, two health centres and one dispensary were visited. Key findings that predispose women to OF include a combination of the following: rugged, physical and expansive landscape, long distances to health facilities, harmful cultural practices, poverty and limited understanding of complications of childbirth. In addition health care providers do not use the partograph in the prevention and management of prolonged/obstructed labour (MOH/UNFPA 2004).

Until recently there were few gynecologists in Kenya who had expertise in obstetric fistula repair in the country and patients treated were not effectively rehabilitated. Although the potential for 
repair of fistula exists at district hospitals, OF repair is not done routinely. However, UNFPA has been supporting the scale up of addressing obstetric fistula. This includes renovations of operating theatres, providing surgical repair equipment and the training of health care providers in the management/repair of obstetric fistula in Machakos district hospital, Nyanza and Coast Provincial General Hospitals and Moi Teaching Hospital in Eldoret. Plans are underway to support an additional four provincial hospitals to ensure countrywide coverage and institutionalization of the said services in the public sector. Only during the last decade has there been hope and innovation for women living with OF. For example, to address the issue of referral of women experiencing obstetric complications during labour and childbirth, UNFPA installed radios in Mwingi and Kwale districts to improve communication between facilities and also facilitated the request for ambulances for referral.

Other actors are supporting the repair of fistula in Kenya. In collaboration with Kenyatta National Hospital (KNH), AMREF holds an annual free medical camp for women with fistula. In the past AMREF has also facilitated repair activities in Garissa, Mutomo, Mumias, Ortum and Nyanza. Jamaa Hospital in Nairobi provides treatment and care for OF with funding from the Safaricom Telephone Network, MSF - Spain and other smaller donations. Kenyatta National Hospital in Nairobi, Moi Teaching Hospital in Eldoret and Machakos Hospital in Eastern Province serve as centres of excellence and provide training for fistula repair teams (a mixed skill team of doctors, nurses and other medical support staff).

The Kenya National Obstetric Fistulae Training Curriculum for Health Care Workers was developed in 2006, with funding and technical support from UNFPA, to train service providers using a multi-disciplinary approach for effective management of obstetric fistula. The approach entails training core teams, which include a doctor, two nurses (one from theatre and one from the ward), anesthetists, physiotherapists, and social workers. Training normally takes two weeks and a minimum of ten clients is required for each team to be competent in repairing and rehabilitating women with fistula. The curriculum has nine modules: anatomy of female reproductive and urinary system; pre, intra and post operative management (including list of essential equipment and supplies for repair); infection prevention; counselling; referral and rehabilitation; advocacy, community involvement, information, education and communication (IEC) activities and prevention; documentation and record keeping; monitoring and evaluation; and research.

Following lobbying by UNFPA, the Kenya Demographic and Health Survey planned for 2008/9 has for the first time incorporated questions on obstetric fistula.

\section{Community Midwifery Strategy}

In 2004 traditional birth attendants (TBAs) conducted over $70 \%$ of the total deliveries in the study districts and many of the cases of prolonged/obstructed labour and subsequent $\mathrm{OF}$ are attributed to their patronage. In Mwingi and Kwale districts communities constructed maternity units in dispensaries apparently to be run by TBAs (MOH/UNFPA 2004). However the recent

Reproductive Health Policy stipulates that TBAs are not considered as skilled attendants and training should be discontinued (DRH/MOH 2006). The National Community Strategy outlines how TBAs can be used as agents for change within the community and encouraged to refer pregnant women to skilled professionals.

In an effort to reduce the high number of births attended by unskilled assistants $\mathrm{MOH} / \mathrm{DRH}$ and Population Council and Nursing Council of Kenya developed and piloted the community midwifery approach in Western Province in 2005. Building on the emerging evidence, and as part 
of the UNFPA Global Campaign to End Obstetric Fistula UNFPA/MOH developed the community midwifery intervention strategy that would increase skilled attendance at birth and reduce the number of obstetric complications. In addition to the $96 \mathrm{CMs}$ trained in Western Province between 2005 -2007, the DRH, with technical and financial support from UNFPA, scaled up the comprehensive community midwifery initiative in Nyandarua and Mwingi districts and subsequently in Taita-Taveta and Kilifi districts thus making 24 districts in Kenya with CMs on the ground. Under the UNFPA programme, 116 Midwives (33 in Nyandarua, 40 in Kilifi, 34 in TaitaTaveta and 12 in Mwingi) have been trained from the four UNFPA supported districts.

\section{Community Midwifery:}

The focus of the Community Midwife is to provide skilled care to pregnant women, new mothers and their newborns. CM services will facilitate reducing the 'three delays'. For example, by encouraging women to make an individual birth plan the $\mathrm{CM}$ will help alleviate the first two delays.

The CM will also contribute to reducing the third delay by informing the health facility of a client requiring urgent attention ahead of time, to ensure that the facility is prepared.

Following the successful piloting and scale up of the community midwifery initiative by both UNFPA and Population Council it was formally launched by the Minister for Health in Bungoma District Western Province in 2006 and incorporated into the new Reproductive Health Policy (2007). The Kenya community midwives (CM) compliment the efforts carried out in health facilities to increase skilled attendance at birth. UNFPA, DRH and Population Council spearheaded the development of Community Midwifery Guidelines and training materials.

A working community midwife has successfully completed competency based updates/skills training, has been certified by the DRH and licensed by the specific professional bodies such as the nursing council to provide these services in the community. The CM can be a retired or out of work health professional or a midwife running a small private clinic, with evidence of a formal qualification in obstetric skills and permanent residence within the community to be served (or prepared to live permanently in that community). The CM links with the health care system through the nearest health facility for support such as updates, transport, supplies, and equipment.

The CM also links with civil society and the provincial administration and community leaders and groups to work as team in the advocacy of maternal and newborn care services as well as work closely with community health extension workers (CHEWs) and community health workers (CHWs) recognizing the role of each in the provision of maternal and newborn health $(\mathrm{MNH})$ in the community. In addition UNFPA provides the CMs with mobile telephones and basic delivery kits and ensures a four wheel drive ambulance is stationed at the district hospital.

This report seeks to understand the experiences of women affected by fistula and whether community midwives can contribute to preventing obstetric fistula in rural settings in Kenya. 


\section{METHODOLOGY}

Both quantitative and qualitative methods of data collection were used during May 2008 in the four UNFPA supported districts: Nyandarua, Mwingi, Kilifi and Taita Taveta (See Appendix 1 for a detailed description of the methodology). Professional midwives with counseling skills and trained in data collection administered structured questionnaires to samples of women living with/who have lived with obstetric fistula (82) as well as women who had experienced obstructed labour (70) and were willing and able to talk about their experiences. Table 1 outlines the sample size by each district.

Table 1: Number of women interviewed in each district: women who experienced obstructed labour (OL) and women living with or who lived with obstetric fistula (OF)

\begin{tabular}{|c|c|c|c|c|c|c|c|}
\hline \multicolumn{2}{|c|}{ Nyandarua District } & \multicolumn{2}{c|}{ Mwingi District } & \multicolumn{2}{c|}{ Kilifi District } & \multicolumn{2}{c|}{ Taita Taveta District } \\
\hline $\mathrm{OL}$ & $\mathrm{OF}$ & $\mathrm{OL}$ & $\mathrm{OF}$ & $\mathrm{OL}$ & $\mathrm{OF}$ & $\mathrm{OL}$ & $\mathrm{OF}$ \\
\hline $\mathrm{N}=25$ & $\mathrm{~N}=9$ & $\mathrm{~N}=16$ & $\mathrm{~N}=26$ & $\mathrm{~N}=7$ & $\mathrm{~N}=33$ & $\mathrm{~N}=22$ & $\mathrm{~N}=14$ \\
\hline
\end{tabular}

The researchers also interviewed community midwives (56) to assess the extent of CM practice and challenges faced in providing maternal and newborn services in the four districts. Hospital records for women who experienced obstructed labour were also reviewed (51) and the capacity of the district hospitals to carry out fistula repairs was assessed (7). A team of four social scientists facilitated focus group discussions (FGDs) with both men and women from the four districts (4 FGDs per district) to determine their perceptions around maternal care and challenges they face as well as the knowledge and support for community midwifery services. Group discussions with facility-based health providers also took place (4).

\section{Study districts}

Although the four study districts are culturally, geographically (mountainous, coastal, vast plains) and socio-economically diverse, common factors emerged. All four districts have low levels of skilled attendants during childbirth. According to the 2007 district reports, the proportion of women who received no professional assistance at childbirth was recorded as $47 \%$ in Nyandarua, 65\% in Mwingi, 60\% in Taita Taveta and 73\% in Kilifi. These proportions are higher (apart from Nyandarua) than the national rate of 58 percent of deliveries without a skilled attendant (KDHS 2003).

Kilifi District is in Coast Province and borders Taita-Taveta to the west, Malindi to the north west, Mombasa and Kwale to the south. With a population of around 678,698, it is estimated that over $75 \%$ of the population live below the poverty line and $30 \%$ of these are extremely poor. Kilifi District has total of 73 health facilities distributed across the district. Accessibility of health services is, however low and $57 \%$ of the population live over $5 \mathrm{kms}$ from the nearest health facility. Main problems affecting reproductive health include: inadequate quality of care during ante/postnatal period, high unmet need of family planning, low literacy levels among women and low male involvement in RH. (Source: Kilifi District Health Plan 2007/2008).

Mwingi District is one of the Districts in Eastern Province and covers an area of 9,910sqkm with a population of 368,832 . It borders Tharaka District to the North, Tana River District to the East, Kitui District to the South, Machakos to the West and Mbeere to the North East. Mwingi District is generally made up of plains with rocky outcrops; the climate is hot and dry for the greater part of the year. Poverty is estimated at 60 percent with the poor residing in the driest divisions. The district has one hospital, two sub district hospitals, nine health centres and 53 dispensaries. The top causes of morbidity and mortality are malaria, upper respiratory tract 
infections, anemia, diarrheal diseases, HIV/AIDS, and accidents. The main constraints in health service delivery are shortage of staff, poverty, poor infrastructure and shortage of equipment (Mwingi District Health Plan 2007/2008).

Nyandarua District is in Central Province and borders Laikipia District to the North, Nyeri and Murang'a District to the East, Kiambu and Nakuru District to the south and west respectively. The altitude of Nyandarua varies between $3999 \mathrm{~m}$ above sea level on the Aberdares mountain ranges to $1828 \mathrm{~m}$ towards the floor of the Great Rift Valley. There are nine hospitals in the district: six private, one faith-based and two government hospitals, nine health centers (all GOK), seven nursing/maternity homes (all private), 42 dispensaries and 159 private clinics (Source: Nyandarua District Health Plan 2007/2008).

Taita Taveta District is in Coast Province with a population of 267 993. It borders Tana River, Kitui and Makueni Districts to the north, Kwale and Kilifi Districts to the east, Kajiado District to the northwest and the Republic of Tanzania to the south and southwest. The district covers approximately $17,000 \mathrm{sq} \mathrm{km} \mathrm{(62 \%} \mathrm{covered} \mathrm{by} \mathrm{the} \mathrm{Tsavo} \mathrm{National} \mathrm{Park).} \mathrm{The} \mathrm{district} \mathrm{has}$ mountainous and low land terrains which coupled with the poor road net work makes most areas inaccessible especially during the rains. Most of the inhabitants are poor peasant farmers. There are 40 health facilities: 3 hospitals 8 health centers and 29 dispensaries. The important health problems are communicable diseases such as malaria, respiratory tract infection, diarrheal diseases and HIV/AIDS. Constraints to health care service delivery include: inadequate trained personnel, inadequate laboratory services, poor data collection, and management. (Source: Taita Taveta District Health Plan 2007/2008).

\section{Figure 1 Study Districts}

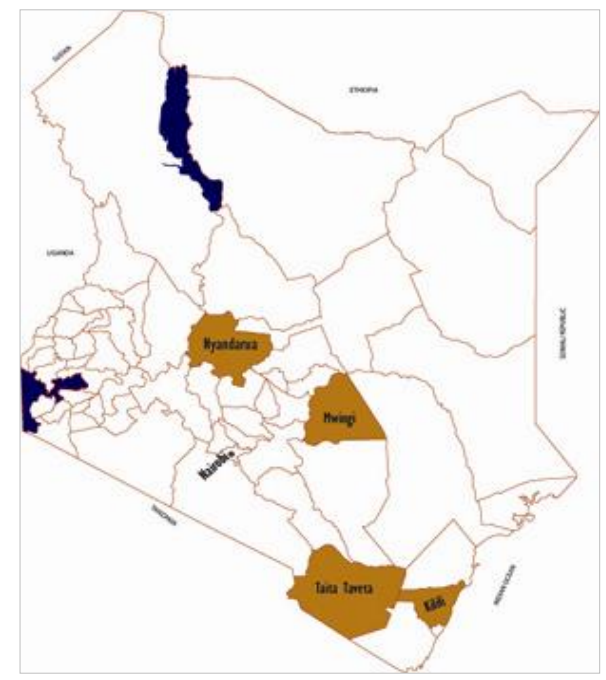

\section{Magnitude of obstetric fistula in the study districts}

Data on obstetric fistula were not readily available at the district level and where available, information was very limited. Some women affected by fistula were found through hospital records but the majority of the women were found through contact tracing through community midwives and other community members following the FGDs. The fact that over 80 women were identified in just over three weeks indicates that the magnitude of OF in these districts specifically Kilifi, Mwingi and Taita Taveta could be much higher than originally thought. There appeared to be fewer women with fistula in Nyandarua district possibly due to the higher facility delivery rate. 


\section{Characteristics of women living with obstetric fistula or who have experienced obstructed labour}

Table 2 outlines the characteristics of the two groups of women interviewed for this study. The table compares women interviewed in maternity units who experienced obstructed labour (OL) and women who are living with/ who have lived with obstetric fistula (OF).

This data reinforces the evidence from other studies; poor, illiterate women are more likely to suffer the consequences of prolonged and obstructed labour (UNFPA 2003, Kenya MOH and UNFPA 2005, Bangser and Mehta 2006). Significant differences between the two groups were noted among those who did not attend school and could not read English or Kiswahili as well as their earning capacity. Women living with / who had lived with OF were more likely to have had a co-wife and be separated or divorced. More than a third of women had a co-wife in Kilifi $(34 \%)$ and Taita Taveta $(31 \%)$ districts. Women in the OF group were more likely to have husbands who did not attend school.

Table 2: Socio- demographic characteristics of: women who have experienced obstructed labour (OL) and women who are living with/ who have lived with obstetric fistula (OF)

\begin{tabular}{|c|c|c|c|c|c|}
\hline \multirow[t]{2}{*}{ Indicators } & \multicolumn{2}{|c|}{$\begin{array}{l}\text { Obstructed Labour } \\
\text { only }\end{array}$} & \multicolumn{2}{|c|}{$\begin{array}{c}\text { OL leading } \\
\text { to Obstetric Fistula }\end{array}$} & \multirow[t]{2}{*}{ P-Value } \\
\hline & $\%$ & $\mathbf{N}$ & $\%$ & $\mathbf{N}$ & \\
\hline \multicolumn{6}{|l|}{ General characteristics: } \\
\hline Attended school & 94 & 70 & 62 & 82 & $0.00^{* *}$ \\
\hline Could not read either English or Kiswahili & 12 & 69 & 48 & 82 & $0.00^{* *}$ \\
\hline Completed 8 year primary education & 41 & 66 & 16 & 51 & $0.00^{* *}$ \\
\hline Completed 4 year secondary education & 20 & 65 & 6 & 51 & $0.02^{*}$ \\
\hline Are currently working & 43 & 70 & 46 & 82 & 0.66 \\
\hline Earn less than Kshs 2000 & 3 & 30 & 41 & 37 & $0.00^{* *}$ \\
\hline Live with partner & 88 & 56 & 79 & 39 & 0.29 \\
\hline Has/had co-wife/wives & 14 & 57 & 37 & 70 & $0.00^{* *}$ \\
\hline Are divorced or separated & 4 & 70 & 23 & 82 & $0.00^{* *}$ \\
\hline Husband never attended school & 3 & 58 & 31 & 68 & $0.00^{* *}$ \\
\hline Mean age & \multicolumn{2}{|c|}{$\begin{array}{l}27 \text { years } \\
\text { (range } 18-33 \text { yrs) }\end{array}$} & \multicolumn{3}{|c|}{$\begin{array}{l}32 \text { years } \\
\text { (range } 18 \text { to } 83 \text { years) }\end{array}$} \\
\hline
\end{tabular}

Women living with OF are less likely to be employed or have an income generating activity. Their poor education background appears to increase their vulnerability to limited economic capacity. Almost all $(90 \%)$ of the women interviewed were not employed and most of the women $(93 \%)$ spent their childhood in the rural setting. Significantly more of the respondents in the OF group said their monthly income was lower than the OL group (84\% vs. 53\%). A number of women said they had worked in the last 12 months: in Nyandarua district (40\%), in Mwingi (5\%), Kilifi (15\%) and Taita Taveta (9\%). Interestingly over two-thirds of women $(72 \%)$ said it is for them to decide how to spend the money that they earn. Nevertheless sixty percent of the women said their earnings cover half or less than half of the household expenditure. Around 60 percent of women lived within five kilometers of a health facility. Table 3 indicates some differences across the districts that may contribute to poor health seeking behaviour. Women with higher education and better income and family support are generally more likely to seek health care promptly. 
Table 3: Demographic indicators by district (all women interviewed)

\begin{tabular}{|l|c|c|c|c|}
\hline Indicator & $\begin{array}{c}\text { Districts } \\
\text { Nyandarua } \\
(\mathrm{n}=34) \\
\%\end{array}$ & $\begin{array}{c}\text { Mwingi } \\
(\mathrm{n}=42) \\
\%\end{array}$ & $\begin{array}{c}\text { Kilifi } \\
(\mathrm{n}=40) \\
\%\end{array}$ & $\begin{array}{c}\text { Taita Taveta } \\
(\mathrm{n}=36) \\
\%\end{array}$ \\
\hline Has never attended school & 0 & 33 & 43 & 11 \\
\hline Cannot read English or Kiswahili & 6 & 43 & 48 & 22 \\
\hline Completed 8 years of primary education & 35 & 36 & 17 & 29 \\
\hline Monthly income below Ksh 5,000 & 53 & 100 & 73 & 66 \\
\hline Divorced or separated & 9 & 9 & 23 & 17 \\
\hline
\end{tabular}

Table 4 summarizes age difference between the women and their husband at first marriage and wanted-ness of first pregnancy. Significantly more women living with OF had husbands who were more than 10 years older than themselves. The mean age at both first marriage and first pregnancy was 21 years in the OL group and 19 years in the OF group. The age of first sex for women in the OL group ranged from 13 years to 31 years (mean =19). In the OF group, age at first sex ranged from 10 years to 25 years $($ mean $=17$ ). This was significantly different between the two groups. The group of women living with / had lived with OF was more likely to have had more births. This is probably due to the fact that there were a number of much older women in the OF group (mean age 37 vs. 27 years).

Table 4: Age of women and their husbands at marriage and age at first pregnancy

\begin{tabular}{|c|c|c|c|c|c|}
\hline \multirow{2}{*}{$\begin{array}{l}\text { Indicators } \\
\text { At the time of first marriage: }\end{array}$} & \multicolumn{2}{|c|}{$\begin{array}{l}\text { Obstructed } \\
\text { Labour only }\end{array}$} & \multicolumn{2}{|c|}{$\begin{array}{c}\text { OL leading } \\
\text { to Obstetric Fistula }\end{array}$} & \multirow{2}{*}{$\begin{array}{l}\text { P- } \\
\text { Value }\end{array}$} \\
\hline & $\%$ & $\mathbf{N}$ & $\%$ & $\mathbf{N}$ & \\
\hline Was older than husband & 2 & 59 & 1 & 71 & 0.89 \\
\hline Was about the same age with husband & 15 & 59 & 23 & 71 & 0.29 \\
\hline Was younger than husband $<$ than 10 years & 63 & 59 & 34 & 71 & $0.00^{* *}$ \\
\hline Was younger than husband $>10$ years & 18 & 59 & 39 & 71 & $0.01^{* *}$ \\
\hline Don't know husbands age & 2 & 59 & 3 & 71 & 0.67 \\
\hline \multicolumn{6}{|l|}{ At the time of first pregnancy: } \\
\hline Wanted to have baby at that time & 60 & 70 & 59 & 82 & 0.85 \\
\hline Wanted to have baby later & 23 & 70 & 19 & 82 & 0.61 \\
\hline Did not want to have baby at all & 17 & 70 & 22 & 82 & 0.45 \\
\hline Mean age at first sexual intercourse & 19 & 69 & 17 & 73 & $0.00^{* *}$ \\
\hline Mean age at first pregnancy & 21 & 69 & 19 & 76 & $0.00^{* *}$ \\
\hline
\end{tabular}




\section{THE CHALLENGES OF OBSTETRIC FISTULA IN KENYA}

Obstetric fistula is a consequence of the prolonged delays in reaching emergency obstetric care. For the majority of home deliveries, the underlying causes of maternal morbidity and mortality have been classified according to the "three delays" model (Thaddeus and Maine 1994):

1) Delay in deciding to seek medical care;

2) Delay in reaching appropriate care; and

3) Delay in receiving care at health facilities

\section{Delay in deciding to seek medical care}

This delay stems from a failure to recognize danger signs. This is usually a consequence of a nonskilled person attending the birth, but it may also stem from reluctance within the family or community to send the woman to a care facility due to lack of awareness of the severity of the problem, or financial and/or cultural constraints. Data in this study indicates that majority of the women only realized that there was a problem 21 hours after the onset of labour.

\section{Delay in reaching appropriate care}

The second delay is caused by a lack of access to a referral health facility due to poor infrastructure, lack of appropriate means of transport or a lack of awareness of existing services and where to access them.

Although the majority of the women in the study had made a decision to seek care many of them were not able to access the care until about

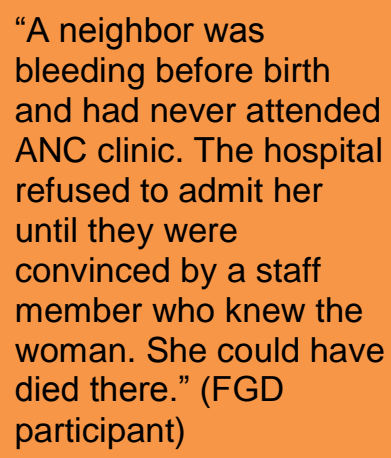
bleeding before birth and had never attended ANC clinic. The hospital refused to admit her until they were convinced by a staff member who knew the woman. She could have died there." (FGD participant) four hour later. In most of the cases transport was seen as the main cause of the delay. One man said, "Sometimes a woman is about $20 \mathrm{~km}$ away from hospital. Since there are no vehicles, you have to carry the woman on your back or sometimes we use sacks to make a stretcher". Male FGD Taita Taveta

\section{Delay in receiving care at health facilities}

The third delay relates to problems within the referral facility which may include admission logistics, inadequate equipment or a lack of trained personnel, emergency medicines or blood. Data from the four study districts showed that women received care 5-11 hours after arriving in the health facility. Negative attitudes of the nursing staff also act as barriers to women receiving timely care once they reach the facility.

\section{Experiences of women living/have lived with fistula}

Three cases studies were selected from the sample of 82 women interviewed living with or had lived with obstetric fistula. These case studies are indicative of the range of all the experiences and highlight the effects of fistula on women.

\section{ONE: A woman living with OF for nearly 50 years - delay in deciding to seek care and finding transport}

A 73 year old married grandmother and mother of three, 'Mary' developed obstetric fistula in 1959 after the delivery of her third child. The client has both VVF and RVF. She did not attend ANC but the pregnancy progressed to term without any complications. Labor was monitored by the mother-in-

"Many women decide to deliver at home and only decide to go to hospital when there is a problem. Some women don't want hospital deliveries at all. In some instances husbands decide but on many occasions, the women decide for themselves and usually when it's too late." (FGD participant) 
law for 24 hours when they realized she could not deliver normally. Since vehicles were not available, she was taken to the nearby market on a wheelbarrow where a mobile clinic van was expected to pass while on its duty from the district hospital. Unfortunately the van used a different route and only picked her on its way back to the district hospital.

She reached the hospital after 36 hours in labour and in a coma. She learnt later what happened. A male infant was stillborn through forceps delivery. She woke up from the coma two weeks after delivery only to realize she could not hold either stool or urine. On reaching home after discharge, the husband sent her away to her parent's home. The father demanded that the husband take responsibility and took the daughter to hospital. The husband later picked her up from the father's home and took her to Coast General Hospital in 1960 and abandoned her there. Later the husband came to sign the consent form for OF treatment and care in the surgical theatre; instead he helped her abscond from hospital. This plan she later learned was that of the mother-in-law. The mother-in-law claimed it was taking a lot of time and money for the treatment and care. When the husband married two more wives, she could not cope with the rejection and ridicule so she left him. She later returned to her marital home when her first born daughter was mature and could look after her. She says her husband has to consent for the treatment and care to be done as she is his property. Mary suffered isolation, shame and stigmatization and has given up hope of treatment and care.

Following the interview the husband sought out and brought his wife to the interviewer with concern about how to arrange for OF treatment and care and said that in 1960 he could not consent for the operation as he was told only a colostomy could help her out. He thought it would be difficult to cope with such at home. He was given information on where to take Mary for medical assessment at the gynecological clinic at the nearest hospital.

\section{TWO: Delay in finding transport to health facility, lack of skilled attendant}

'Anna' is a 41 year old mother of five living children, left school in standard six and is a homemaker. Out of seven pregnancies, two resulted in stillbirths. During the pregnancy in 2001 that caused the fistula, she attended ANC three times at the district hospital. Labor pains started at $4 \mathrm{am}$ and as usual a TBA came to monitor the progress of her labor. She had intense labor pains with no baby forthcoming. At $2 \mathrm{pm}$ she felt something must have gone terribly wrong. Her husband could not find vehicle to take her to hospital, therefore he and other men made a makeshift stretcher using a sack and poles, and carried Anna to Mwingi District Hospital. It took about three hours to get to the hospital, by then contractions had ceased and she had slight bleeding from the vagina.

On examination, she was informed that her uterus had ruptured and her baby was already dead. Anna had to undergo abdominal surgery to remove the dead baby and also repair the torn uterus. She also requested for a tubal ligation during the operation, something that her husband consented to. The operation went smoothly. Anna was left with a catheter which was removed after one week, but then she realized her bed was always wet and she had no urge to pass urine. Anna informed the doctor who after examination told her it was one of the complications of the prolonged labour. Anna was discharged from the hospital still leaking and instructed to go for follow up visit in the clinic. Anna had to cope with the discomfort of having rags in between her thighs to trap the urine. Worse was the bad smell she emitted all the time. She felt isolated and dirty all the time. In 2002 she received treatment and care for the fistula. Leakage did not stop completely and requires further surgery. Anna was referred to the nearest OF management centre. 


\section{THREE: Previous fistula}

'Jane', who married at the age of 19 years, is a 32 year-old mother of four and works as a vegetable vender earning less than Ksh. 2,000 per month. She developed obstetric fistula twice, after her first and fourth pregnancies. Although she remembers little about the first pregnancy and delivery, she recalled the events of the fourth pregnancy. Jane went to the hospital on time but after 10 hours in labour she was told there was no progress; the baby was not descending. Health providers told her that she had to deliver through caesarian section as the baby was getting distressed. Following the operation all seemed well, but after two days when the catheter was removed she started leaking urine. She was catheterized again for ten days but the condition worsened. After discharge and 6 months follow up she was re-admitted and underwent treatment and care of the fistula. A catheter was in place following the operation for 14 days. For the subsequent 3 months she leaked a little and was put on antibiotics; she has now stopped leaking urine. Jane is happy that now she is completely dry and can run her own errands as before. She is very grateful to her husband, mother and mother-in-law who gave her moral, psychosocial and financial support when she most needed it. She also thanks the hospital staff.

\section{Emerging issues from the case studies}

- Women can suffer obstructed labour and subsequent fistula during any pregnancy. This has been shown in previous studies and in the first case study above, Mary developed fistula while delivering her third child.

- Knowledge of maternal health and care seeking behavior remain unchanged in some areas since the 1960s. Community members are still seeking alternative remedies, "One is given traditional herbs to drink to help in the progress of the pregnancy and prevent one form getting any problems" (FGD participant).

- Cultural influences and male dominance continue to hinder women from seeking health care - Mary believes she cannot seek care unless her husband consents to it.

- Poverty - Lack of money prevented Mary from receiving care. Anna still has problems but not yet gone for further treatment and care. Many more may end up with fistulae due to poverty as witnessed from this statement, "We need to make these health facilities affordable. The admission fee for maternity is about 1,000 or 2,000 and most people cannot afford. ... However after a TB $A$ delivers you, you can pay her in kind that is using "lesos", and she will not detain you like the case in hospital without payment" (FGD participant).

- Due to lack of information women such as Mary have "accepted" to live with fistula for a long time (nearly all their adult life). Ignorance about the condition by her and her relatives has made her to stop seeking treatment for the problem.

- Majority of the OF women live as rejects of the society feeling worthless, hopeless and fatalistic. They are either separated or divorced.

- Although some women will seek care from the health care system in time it is known that some women will develop complications such as fistula when under professional care in the facilities e.g Jane sought skilled care on time but developed a fistula. However it is obvious that a previous pregnancy may have pre-disposed her to developing the condition.

- OF can be successfully repaired and women can continue with a healthy life after treatment and care as seen in the case of Jane above. She received encouragement and support from her husband, mother and other in-laws and is now 'dry' and recovered from OF and leading a normal life. 


\section{Factors contributing to the development of fistula}

Table 5 compares the experiences of women who had obstructed labour (OL) with women who were living with / had lived with OF during their first pregnancy to elicit any major differences that may have contributed to the development of obstetric fistula. Women living with or have lived with OF were significantly less likely to attend ANC than those who experienced OL only. Notably more women who experienced OL had a cesarean section and a live baby. Women living with or have lived with OF are significantly more likely to use a TBA and less likely to give birth in a facility or receive any kind of checkup following childbirth. Interestingly women who did not experience obstructed labour or obstetric fistula during their first birth $(n=74)$ were less likely to deliver in hospital or get a health check after delivery.

Table 5: Comparison of ANC attendance, birth outcome and postnatal care at first birth

\begin{tabular}{|c|c|c|c|c|c|c|}
\hline \multirow[t]{2}{*}{ First birth } & \multicolumn{2}{|c|}{ No OL or OF } & \multicolumn{2}{|c|}{$\begin{array}{l}\text { Obstructed } \\
\text { Labour }\end{array}$} & \multicolumn{2}{|c|}{$\begin{array}{l}\text { Obstetric } \\
\text { Fistula } \\
\text { developed }\end{array}$} \\
\hline & $\%$ & $\mathbf{N}$ & $\%$ & $\mathbf{N}$ & $\%$ & $\mathbf{N}$ \\
\hline Attended ANC - at least once & 82 & 74 & 90 & 48 & $71^{* *}$ & 28 \\
\hline Attended ANC - at least four times & 70 & 61 & 58 & 43 & 65 & 20 \\
\hline Live birth & 90 & 60 & 80 & 46 & $25^{\star \star}$ & 28 \\
\hline Neonatal death & 5 & 60 & 7 & 46 & 21 & 28 \\
\hline Stillbirth & 5 & 60 & 13 & 46 & $54^{\star \star}$ & 28 \\
\hline Delivered in hospital & 46 & 74 & 83 & 48 & $61^{*}$ & 28 \\
\hline Delivered in other health facilities & 4 & 74 & 6 & 48 & 7 & 28 \\
\hline Delivered through $\mathrm{C} / \mathrm{S}$ & 13 & 72 & 63 & 48 & $33^{\star \star}$ & 24 \\
\hline Had complications during delivery & $8^{* *}$ & 74 & 100 & 48 & 96 & 28 \\
\hline Hours before realizing problem & - & - & 19 & 46 & 18 & 23 \\
\hline Hours before starting to seek care & - & - & 19 & 44 & 19 & 19 \\
\hline Hours before reaching care & - & - & 21 & 42 & $24^{*}$ & 17 \\
\hline Hours before receiving care & - & - & 27 & 45 & 25 & 22 \\
\hline Someone provided health check & 79 & 73 & 100 & 48 & $89^{*}$ & 28 \\
\hline Provider gave health check & 53 & 74 & 92 & 48 & $75^{\star}$ & 28 \\
\hline No obstructed labour or obstetric fistula & 100 & 74 & 0 & 48 & 0 & 28 \\
\hline Obstructed labour & 0 & 74 & 100 & 48 & $0^{\star *}$ & 28 \\
\hline $\begin{array}{l}\text { Obstructed labour and obstetric fistula } \\
\text { developed }\end{array}$ & 0 & 74 & 0 & 48 & $100^{\star *}$ & 28 \\
\hline
\end{tabular}

Many of the women interviewed were monitored by unskilled persons during the birth of their first child. There are similar patterns for subsequent births. TBAs or mothers/mothers in law were significantly more likely to monitor women in the OF group. Over 70 percent of the women living with or have lived with OF had labour monitored by an unskilled assistant (TBA, mother or mother-in-law) in their first and second births compared to 40 percent to 50 percent of the OL group (see table 6). 
Table 6: Birth attendant and occurrence of obstructed labour and obstetric fistula by birth order

\begin{tabular}{|c|c|c|c|c|c|c|}
\hline \multirow{2}{*}{$\begin{array}{l}\text { Birth order: } \\
\text { First birth }\end{array}$} & \multicolumn{2}{|c|}{$\begin{array}{l}\text { No Obstructed } \\
\text { Labour or } \\
\text { Obstetric Fistula }\end{array}$} & \multicolumn{2}{|c|}{$\begin{array}{l}\text { Obstructed } \\
\text { Labour } \\
\text { only }\end{array}$} & \multicolumn{2}{|c|}{$\begin{array}{l}\text { Obstructed } \\
\text { labour and } \\
\text { Obstetric Fistula } \\
\text { developed }\end{array}$} \\
\hline & $\%$ & $\mathbf{N}$ & $\%$ & $\mathbf{N}$ & $\%$ & $\mathbf{N}$ \\
\hline Labour monitored by nobody & 8 & 74 & 4 & 48 & 4 & 28 \\
\hline Labour monitored by relative(s) & 22 & 74 & 35 & 48 & 36 & 28 \\
\hline Labour monitored by TBA & 23 & 74 & 8 & 48 & $36^{\star \star}$ & 28 \\
\hline Labour monitored by health provider & 41 & 74 & 31 & 48 & 18 & 28 \\
\hline Labour monitored by 2 or more persons & 7 & 74 & 21 & 48 & 7 & 28 \\
\hline Fistula developed & 0 & 74 & 0 & 48 & $100^{\star *}$ & 28 \\
\hline \multicolumn{7}{|l|}{ Second birth } \\
\hline Labour monitored by nobody & 4 & 68 & 0 & 30 & 0 & 13 \\
\hline Labour monitored by relative(s) & 31 & 68 & 27 & 30 & 15 & 13 \\
\hline Labour monitored by TBA & 24 & 68 & 20 & 30 & 54 & 13 \\
\hline Labour monitored by health provider & 34 & 68 & 47 & 30 & 23 & 13 \\
\hline Labour monitored by 2 or more persons & 7 & 68 & 7 & 30 & 8 & 13 \\
\hline Fistula developed & 0 & 69 & 0 & 30 & $100^{*}$ & 13 \\
\hline \multicolumn{7}{|l|}{ Third birth } \\
\hline Labour monitored by nobody & 12 & 49 & 5 & 19 & 0 & 7 \\
\hline Labour monitored by relative(s) & 33 & 49 & 21 & 19 & 0 & 7 \\
\hline Labour monitored by TBA & 18 & 49 & 16 & 19 & 14 & 7 \\
\hline Labour monitored by health provider & 35 & 49 & 47 & 19 & 57 & 7 \\
\hline Labour monitored by 2 or more persons & 2 & 49 & 11 & 19 & 29 & 7 \\
\hline Fistula developed & 0 & 50 & 0 & 20 & $100^{*}$ & 7 \\
\hline \multicolumn{7}{|l|}{ Fourth birth } \\
\hline Labour monitored by nobody & 20 & 36 & 10 & 10 & 8 & 13 \\
\hline Labour monitored by relative(s) & 22 & 36 & 40 & 10 & 31 & 13 \\
\hline Labour monitored by TBA & 22 & 36 & 30 & 10 & 38 & 13 \\
\hline Labour monitored by health provider & 36 & 36 & 20 & 10 & 15 & 13 \\
\hline Labour monitored by 2 or more persons & 0 & 36 & 0 & 10 & 8 & 13 \\
\hline Fistula developed & 0 & 37 & 0 & 10 & $100^{* *}$ & 13 \\
\hline
\end{tabular}


Fistula can occur following any birth and is not limited to any particular birth order (see Figure 1). Nevertheless twenty-eight (out of 81) women interviewed developed fistula at their first birth.

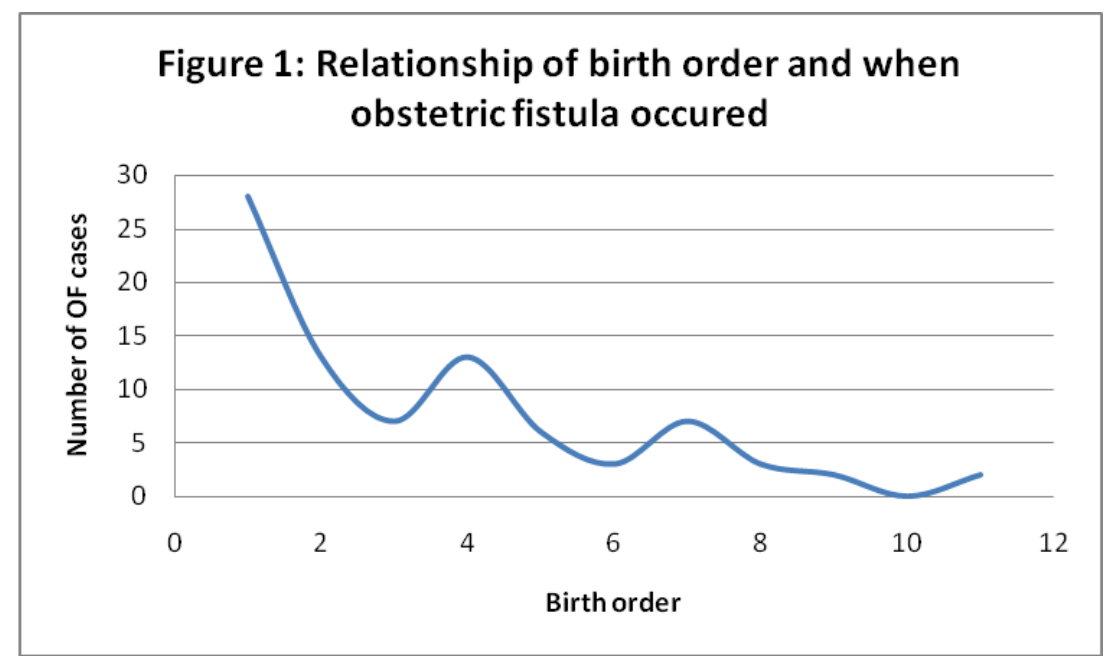

Half of the women were less than 20 years when the fistula occurred, 43 percent were between 20 and 24 years and remaining 7 percent between 25 and 29 years. A similar proportion of women in both groups experienced prolonged/obstructed labour once $68 \%$ for OL group vs. $71 \%$ of the OF group) and more women in the OL group experienced prolonged labour twice $(29 \%$ vs. $18 \%$ ). However the OF group were more likely to experience prolonged labour in subsequent births $(10 \%$ vs. $3 \%)$.

On discovery of fistula a high proportion of women (91\%) sought medical care from a health provider, mainly at the hospital level $(86 \%)$. Although only 68 percent of women were informed by a health provider how the fistula occurred. Almost all (99\%) women in the OF group could not hold urine as a result of prolonged childbirth. Eleven percent of the women were not able to hold stool either. Few women said they were in constant pain $(5 \%)$ and ten percent said they also had problems walking. Around half $(52 \%)$ noticed they were leaking urine immediately after delivery, 27 percent within 4 to 7 days, and 21 percent within the first month of delivery.

While the data shows that some of the women have lived with OF for decades, 72 percent $(\mathrm{n}=$ 59) of the women with OF were repaired. Just under half (47\%) were operated on once, 32 percent were operated on twice and 21 percent were operated on 3 to 5 times. Sixty-one percent had treatment and care for vesico -vaginal fistula and 12 percent treatment and care for vesico and recto-vaginal fistula. The remaining 27 percent of women were not aware of the details of the operation. About two-thirds of the women interviewed (68\%) said that the OF treatment and care was successful. They described themselves as now "being dry". Three women $(5 \%)$ said they had also had a hysterectomy, although a further 49 percent did not know whether they still had their womb.

Seventy percent of the women had fistula treatment and care carried out in the last two years. Only 19 percent were carried out more than five years ago. This indicates the success of active campaigns and awareness creation of fistula in Kenya in recent years. Treatment and care for OF was not specifically done in the study district facilities. Most women were provided with treatment and care for OF in Coast PGH (42\%) and Jamaa Mission Hospital in Nairobi (24\%). Data shows that four women from Taita Taveta district went to neighbouring Tanzanian Health facilities for repair of OF. 


\section{Psychosocial implications of fistula}

Women with obstetric fistula are psychologically traumatized and often faced the challenge of stigma. In this study 38 percent of women said their husband was the first person they informed and around half (54\%) received support from the husbands. However, 23 percent of their husbands became abusive; another 23 percent deserted or abandoned them. Women from Kilifi were more likely to receive abuse (35\%) from their husbands than in the other districts.

Women feel much better off following treatment and care of the fistula. Almost all (97\%) said their family and community were very welcoming when they returned home $(\mathrm{n}=39)$. The majority are able to socialize normally and carry out her activities. Asked to comment on how they felt after successful treatment and care, the women said the following:

- I have a new job $(23 \%)$

- I am able to socialize freely again $(20 \%)$

- Feels cleaner/does not smell anymore (15\%)

- I am free and independent again (13\%)

- I feel like a woman/human being again (8\%)

- I have a new husband $(5 \%)$

Three-quarters of the women received complete treatment and care for fistula $(n=40)$ and are in a relationship. Many $(63 \%)$ are still with their original husbands; 23 percent have a boyfriend, 7 percent have a new husband and 7 percent are with a casual partner. Around half $(53 \%)$ had resumed sexual relations following successful treatment and care. A third (33\%) of those who had not resumed sexual activity feared the problem would re-occur or had not yet healed properly $(39 \%)$. However a majority $(74 \%)$ of these women $(n=19)$ expressed their interest in resuming sex once they were sure they were healed.

Many women (61\%) were still menstruating; 81 percent of these women said they had regular menses. Among those women who had used a family planning method before $(n=27)$, only half $(52 \%)$ were using a method at the time of the interview. The main FP methods used were: injectables ( 9 women), sterilization ( 3 women), condoms (one woman) and LAM (one woman). Almost half of the women wanted another baby in the future. And 48 percent of these want a baby within the next two years.

Despite some of the improvements in their lives quite a few women described challenges that they had experienced which still demonstrate what is at stake for those women who do not seek quality maternal health services in time. Table 7 indicates some of the issues women raised.

\section{Table 7 Challenges experienced by women living with fistula}

\begin{tabular}{|l|c|c|}
\hline Challenges experienced & $\%$ & N \\
\hline Fear of isolation/discrimination by community & 22 & 18 \\
\hline Fear of losing/loss of husband/sexual partner & 17 & 14 \\
\hline Hopelessness due to inability to heal & 17 & 14 \\
\hline Discomfort due to ulceration, irritation, smell of urine & 15 & 12 \\
\hline Financial constraints & 10 & 8 \\
\hline Frequent hospitalization & 5 & 4 \\
\hline
\end{tabular}

Most respondents from the focus group discussions in the community were aware of the stigma associated with obstetric fistula. Women are lonely and become isolated because of the smell and are even ostracized and neglected by family members. 
However many agreed that people need to be sensitized about the problem and that women should be supported: "The woman was a young girl. She was being given herbal remedies but they took her to hospital when it didn't work. Her husband used to feel very sorry for her because he loved her, giving a hand to bousework and her parents-in-law assisted by taking her to hospital" (male respondent Taita Taveta district).

\section{Community knowledge}

The response to a complication during labour and childbirth depends on the perceived severity and cause, and may lead to inappropriate or delayed treatment. Community perceptions of the causes of obstructed labour are varied and often incorrect. Some men in Nyandarua felt that obstructed labour was due to a lack of exercise and the unwillingness of women to do housework during pregnancy. Men in Mwingi and women in Kilifi and Nyandarua believe it is caused by overwork such as too much digging and bending in late pregnancy. Other people think prolonged labour is due to witchcraft; they think the woman has been looked at with evil eyes (Mwingi and Kilifi). Some community members in Taita Taveta believe that a woman who did not really want to be pregnant will suffer from prolonged/obstructed labour.

Nevertheless a number of community members knew that if "the child is too big" problems during delivery are likely to occur. They were also aware that it seems to happen more frequently in young girls. Men in all four districts indicated that if women did not attend ANC and did not seek professional care during labour and childbirth, obstructed labour was more likely to happen. Men and women in FGDs in all four districts said that women with obstructed labour become very weak and require an operation to deliver the baby. Nevertheless some community members said that herbalists may treat the problem, and many still believe it is incurable.

Women in the community know that obstructed labour can cause the death of a mother and baby, serious abdominal pain and excessive bleeding. "... There are women who will leak urine continuously because of that pain. Very few open up. Some think that it is sexually transmitted disease or they are bewitched, then they don't tell anyone," (Woman FGD respondent Taita Taveta district).

Both men and women in the FGDs had heard of obstetric fistula which causes 'leakage of urine'. Few however were aware of recto-vaginal fistula. Some knew that OF is caused by large babies or poor quality of care (woman delivered by student nurse) but that it can be repaired. "I heard about one whose bladder was torn after the baby came out. She went to Kenyatta for treatment and care. I heard she used to use nappies before the operation, after which she was okay," (Woman FGD respondent Nyandarua district).

\section{Community response to the three delays}

Respondents across all four districts were asked to give their opinion on why many women experience maternal and newborn health problems. Table 8 summarizes the communities' perceptions of why mothers might experience problems during pregnancy, labour and childbirth. Their suggestions on how to improve the situation within the context of the three delays are also indicated. 


\begin{tabular}{|c|c|c|}
\hline DELAY & $\begin{array}{l}\text { Community diagnosis of maternal } \\
\text { and newborn health problems }\end{array}$ & $\begin{array}{l}\text { Community suggestions to improve } \\
\text { maternal and newborn health }\end{array}$ \\
\hline \multirow{4}{*}{$\begin{array}{l}\text { 1) What are the } \\
\text { factors } \\
\text { contributing to } \\
\text { the delays in } \\
\text { seeking skilled } \\
\text { maternal and } \\
\text { newborn care? }\end{array}$} & $\begin{array}{l}\text { When a mother fails to attend ANC } \\
\text { during her pregnancy, she becomes } \\
\text { reluctant to deliver there for fear of } \\
\text { ridicule by the providers }\end{array}$ & $\begin{array}{l}\text { Community health education to mothers to } \\
\text { seek medical care in pregnancy } \\
\text { Improve provider attitudes }\end{array}$ \\
\hline & $\begin{array}{l}\text { Women who do not know their } \\
\text { expected delivery date (EDD) may also } \\
\text { be caught unaware by labour. It may } \\
\text { take them time to decide to seek } \\
\text { medical attention at the facility }\end{array}$ & \multirow[t]{2}{*}{$\begin{array}{l}\text { Health education to mothers and their } \\
\text { families to seek medical care in pregnancy }\end{array}$} \\
\hline & $\begin{array}{l}\text { Women do not inform their husbands } \\
\text { when labour starts and complications } \\
\text { often start at night }\end{array}$ & \\
\hline & Lack of a companion during labour & $\begin{array}{l}\text { Mothers need to be educated on birth } \\
\text { preparedness and seek skilled care }\end{array}$ \\
\hline \multirow{5}{*}{$\begin{array}{l}\text { (Decision making } \\
\text { to seek skilled } \\
\text { health care) }\end{array}$} & $\begin{array}{l}\text { Early pregnancy stigmatizes young } \\
\text { girls confining themselves to the home }\end{array}$ & Adolescent health education \\
\hline & $\begin{array}{l}\text { Belief that all women at all times can } \\
\text { deliver naturally - Women who have } \\
\text { had successful home deliveries before } \\
\text { think they have no reason to deliver at } \\
\text { the health facility }\end{array}$ & $\begin{array}{l}\text { Health education; trained CMs have been } \\
\text { educating them on safe pregnancy and } \\
\text { delivery; ANC attendance to detect any } \\
\text { abnormalities; Educate the community } \\
\text { especially husbands on basic obstetric } \\
\text { issues to seek timely medical care }\end{array}$ \\
\hline & $\begin{array}{l}\text { False assurance from TBAs that all is } \\
\text { well }\end{array}$ & $\begin{array}{l}\text { Community midwifes to educate on safe } \\
\text { pregnancy and delivery, need for ANC and } \\
\text { skilled care. Discourage use of TBA } \\
\text { services }\end{array}$ \\
\hline & $\begin{array}{l}\text { Cultural and traditional beliefs } \\
\text { encourage women to deliver at home }\end{array}$ & $\begin{array}{l}\text { If the } \mathrm{CM} \text { is available within the community } \\
\text { they will be able to advise appropriately }\end{array}$ \\
\hline & $\begin{array}{l}\text { Religious beliefs hinder women from } \\
\text { seeking care in health facilities }\end{array}$ & Health education \\
\hline \multirow{5}{*}{$\begin{array}{l}\text { 2) What hinders } \\
\text { mothers with } \\
\text { complications } \\
\text { reaching skilled } \\
\text { care? }\end{array}$} & $\begin{array}{l}\text { Unreliable means of transport, } \\
\text { Impassable roads during floods due to } \\
\text { lack of bridges }\end{array}$ & $\begin{array}{l}\text { Infrastructure development to ease } \\
\text { transport and communication }\end{array}$ \\
\hline & Transport and referral problems & $\begin{array}{l}\text { Family / community help financially, make } \\
\text { stretchers to take mother to hospital } \\
\text { Ambulances to be available }\end{array}$ \\
\hline & $\begin{array}{l}\text { Lack of health facilities or health facility } \\
\text { too far. Too few CMs }\end{array}$ & $\begin{array}{l}\text { Construction of new health facilities. } \\
\text { Train more CMs }\end{array}$ \\
\hline & $\begin{array}{l}\text { Lack of money to pay for hospital } \\
\text { service fees (poverty) }\end{array}$ & $\begin{array}{l}\text { The family and community help financially/ } \\
\text { empower the community economically }\end{array}$ \\
\hline & Insecurity & $\begin{array}{l}\text { Government to improve security situation in } \\
\text { the villages especially at night }\end{array}$ \\
\hline
\end{tabular}




\begin{tabular}{|l|l|l|}
\hline DELAY & $\begin{array}{l}\text { Community diagnosis of maternal } \\
\text { and newborn health problems }\end{array}$ & $\begin{array}{l}\text { Community suggestions to improve } \\
\text { maternal and newborn health }\end{array}$ \\
\hline $\begin{array}{l}\text { 3) Delay within } \\
\text { health facility }\end{array}$ & $\begin{array}{l}\text { (Unqualified health providers) Attended } \\
\text { to by MTC students who cannot } \\
\text { diagnose obstructed labour }\end{array}$ & $\begin{array}{l}\text { Provide more qualified staff to supervise or } \\
\text { oversee trainees }\end{array}$ \\
\cline { 2 - 3 } & $\begin{array}{l}\text { Mother's own naivety e.g. refusing to } \\
\text { sign consent for operation until the } \\
\text { husband is present }\end{array}$ & $\begin{array}{l}\text { Empower women so they make own } \\
\text { decisions }\end{array}$ \\
\hline $\begin{array}{l}\text { Absconding of duty by physicians } \\
\text { (negligence) and poor staff attitudes at } \\
\text { facilities }\end{array}$ & $\begin{array}{l}\text { Instill discipline in health facility workforce } \\
\text { Educate health providers on client/public } \\
\text { relations }\end{array}$ \\
\hline $\begin{array}{l}\text { Lack of or inadequate number of } \\
\text { physicians }\end{array}$ & $\begin{array}{l}\text { Employ more skilled physicians in all health } \\
\text { centers }\end{array}$ \\
\hline $\begin{array}{l}\text { Lack of supplies such as gloves that } \\
\text { facility may require to admit the mother } \\
\text { in labour }\end{array}$ & $\begin{array}{l}\text { Equip and ensure consistent provision of } \\
\text { supplies and drugs to health facilities }\end{array}$ \\
\hline $\begin{array}{l}\text { Inadequate bed capacity at health } \\
\text { facilities }\end{array}$ & Upgrade existing health facilities \\
\hline
\end{tabular}

\section{Quality of emergency obstetric care in seven Comprehensive Emergency Obstetric Care (CEOC) facilities in the four districts}

Fifty-one case notes for obstructed labour were reviewed from the comprehensive obstetric care facilities in the four districts. All cases reviewed were delivered by emergency caesarean section. The mean age of women undergoing emergency caesarean section was 25 years with a range of 15 to 47 years. Mean parity and gravidity was two. None of the records reviewed indicated whether the women had a previous history of stillbirths or neonatal deaths. Table 9 outlines some of the measurements recorded during women's stay in hospital.

Table 9: Record reviews of obstructed labour which resulted in caesarean section

\begin{tabular}{|l|c|c|c|c|c|}
\hline Measurements recorded & $\begin{array}{c}\text { Nyandarua } \\
(\mathbf{n = 1 2})\end{array}$ & $\begin{array}{c}\text { Mwingi } \\
(\mathbf{n}=\mathbf{1 0})\end{array}$ & $\begin{array}{c}\text { Kilifi } \\
(\mathbf{n = 1 4 )}\end{array}$ & $\begin{array}{c}\text { Taita } \\
\text { Taveta } \\
(\mathbf{n = 1 5})\end{array}$ & $\begin{array}{c}\text { Total \% } \\
(\mathbf{n}=\mathbf{5 1})\end{array}$ \\
\hline BP recorded on admission & 8 & 10 & 13 & 13 & 86 \\
\hline Pulse recorded on admission & 6 & 9 & 10 & 9 & 67 \\
\hline Temperature recorded o/a & 3 & 6 & 9 & 8 & 51 \\
\hline Time of admission recorded & 11 & 10 & 5 & 15 & 80 \\
\hline Time of diagnosis recorded & 11 & 7 & 3 & 15 & 71 \\
\hline Time of operation started & 6 & 7 & N/A & 10 & 62 \\
\hline Time of delivery recorded & 12 & 5 & 7 & 11 & 69 \\
\hline More than 2 hours from diagnosis to delivery & 4 & 4 & N/A & 8 & 43 \\
\hline Date of discharge recorded & 9 & 9 & 12 & 14 & 86 \\
\hline
\end{tabular}

Blood for grouping and cross matching was taken in 76 percent of the cases but in only 37 percent of the cases was the administration of IV fluids commenced once diagnosis of obstructed labour was made. Antibiotics were given in 57 percent of the cases following surgery. 
In just over half of the case notes was a urinary catheter inserted prior to cesarean section $(\mathrm{C} / \mathrm{S})$. However all clients had a catheter inserted in Nyandarua, but only 3/10 in Mwingi; 7/13 in Kilifi and 7/14 in Taita Taveta. Four catheters were inserted in Taita Taveta hospitals after the surgery. Even with catheters in situ, very few case notes $(22 \%)$ recorded that actual urinary output was monitored. For less than half of the case notes was the date recorded when the urinary catheter was removed.

The outcome of the index pregnancy indicates some challenges in ensuring quality of care during labour and delivery with 16 percent of the deliveries reviewed resulting in death of the newborn; 4 fresh still births, one macerated still birth and 3 neonatal deaths. Four of the case notes recorded ruptured uterus; two in Mwingi, and one in Taita Taveta and Kilifi. Hysterectomy was performed in two cases.

The mean number of days that the women stayed in hospital was 9 days with a range from 1 to 12. The majority of women were recorded to be discharged home $(92 \%)$, two percent referred and in six percent of the case notes no record was made on what happened to the client.

Table 10 outlines whether specific hospitals in the study districts currently carry out the treatment and care of fistula and the availability of medical personnel and equipment.

Table 10: Capacity of hospitals to treatment and care fistula

\begin{tabular}{|l|c|c|l|}
\hline Hospital & $\begin{array}{l}\text { Repairs } \\
\text { done }\end{array}$ & $\begin{array}{l}\text { Physician } \\
\text { trained }\end{array}$ & Equipment for OF available \\
\hline Kilifi Hospital & Yes & None \\
\hline Mwingi Hospital & Yes & Yes & $\begin{array}{l}\text { All except thorax scissors, } \\
\text { aneurysm needle, sutures, } \\
\text { spinal anesthesia, theatre } \\
\text { table }\end{array}$ \\
\hline Nyahururu Hospital & Yes & Yes & All equipment available \\
\hline Ol Kalou Hospital & No & No & $\begin{array}{l}\text { Have all equipment except } \\
\text { Aurvard speculum }\end{array}$ \\
\hline Taita Taveta Hospital & No & No & All equipment available \\
\hline Voi Hospital & No & Yes & No equipment available \\
\hline Wesu Hospital & No & No & $\begin{array}{l}\text { All except Sims speculum and } \\
\text { Methylene blue }\end{array}$ \\
\hline
\end{tabular}

\section{Can community midwives make a difference?}

All community midwives interviewed $(n=56)$ had been employed since qualifying from college and 61 percent now run a private clinic in the community although in Nyandarua 81 percent operated private clinics; just over half were trained in community midwifery during 2006 (55\%), 2 percent in 2007, and 43 percent in 2008. Seventy percent were female. Most CMs (91\%) were enrolled nurses/midwives; enrolled nurse midwives (42\%), enrolled community health nurses $(38 \%)$ and enrolled midwives $(11 \%)$. The remaining 9 percent were registered nurses. A majority had received updates in focused antenatal care and essential obstetric care. Only half of the CMs recalled receiving updates in family planning (FP) and only 34 percent on obstetric fistula.

Almost all CMs (98\%) are attached to a health facility for support and can expect to receive essential supplies to carry out their work. Half of the CMs are attached to dispensaries and health centres and 40 percent to district hospitals. The remaining CMs are attached to private facilities. 
Almost three quarters (74 percent) of the CMs live less than $5 \mathrm{~km}$ from the facilities, although only a 30 percent of CMs in Mwingi live within $5 \mathrm{~km}$ of facility compared to 8 out of 12 in Kilifi. Only Mwingi and Taita Taveta districts have CMs living more than $10 \mathrm{~km}$ from the health facilities.

Early identification of complications prompts timely interventions. Community midwives were asked to mention the danger signs of complications likely to happen during labour and childbirth that they usually discussed with pregnant women. More than half $(55 \%)$ of CMs said they discussed the danger of labour pains for more than 12 hours, (80\% from Mwingi, and 33\% from Kilifi) during the antenatal period. Most (98\%) CMs rated haemorrhage as the number one direct cause of maternal death, followed by obstructed labour at 70 percent.

\section{Knowledge on signs of obstructed labour}

Diagnosing obstructed or prolonged labour: in order to assess the knowledge of the 56 community midwives a composite score was constructed using five indices: 1) Foetal head may be palpable above the pelvic brim although the woman is in established labour; 2) frequent and very strong contractions with minimal or no cervical dilatation of the cervix; 3) presence of a Bandl's ring; 4) meconium liquor; 5) excessive moulding of foetal head.

Table 11 outlines the scores by district. Midwives in Taita Taveta appeared to be more aware than those in the other districts. This may be due to the fact they had been trained most recently (within two months), however Kilifi midwives were also trained at the same time and did not do so well.

Table 11 Community midwives' knowledge of signs of obstructed labour

\begin{tabular}{|c|c|c|c|c|c|}
\hline $\begin{array}{l}\text { Diagnosing of obstructed or prolonged } \\
\text { labour: }\end{array}$ & $\begin{array}{c}\text { Nyandarua } \\
\text { (n=21) } \\
\%\end{array}$ & $\begin{array}{c}\text { Mwingi } \\
(n=10) \\
\%\end{array}$ & $\begin{array}{c}\text { Kilifi } \\
\text { (n=12) } \\
\%\end{array}$ & $\begin{array}{c}\text { Taita Taveta } \\
\text { (n=13) } \\
\%\end{array}$ & $\begin{array}{c}\text { Total } \\
\begin{array}{c}(n=56) \\
\%\end{array}\end{array}$ \\
\hline $\begin{array}{l}\text { Foetal head palpable above the pelvic } \\
\text { brim }\end{array}$ & 52 & 80 & 58 & 77 & 64 \\
\hline $\begin{array}{l}\text { Frequent and very strong contractions } \\
\text { with minimal or no cervical dilatation }\end{array}$ & 43 & 90 & 58 & 62 & 59 \\
\hline Presence of Bandl's ring on abdomen & 48 & 50 & 33 & 100 & 57 \\
\hline Meconium stained liquor & 19 & 40 & 8 & 46 & 27 \\
\hline Excessive moulding of foetal head & 10 & 20 & 17 & 62 & 25 \\
\hline Total score (0-5) & 1.7 & 2.8 & 1.7 & 3.5 & 2.3 \\
\hline
\end{tabular}

Table 12 indicates community midwives knowledge on complications of obstructed labour, and although high across the districts, CMs in Nyandarua district were less likely to mention rupture of uterus and obstetric fistula. Researchers were able to trace more women with OF in Kilifi district which may indicate a higher number than in other districts. However, only 58 percent of the midwives in Kilifi mentioned OF as a complication of obstructed labour. 
Table 12: CM knowledge of complications of obstructed labour

\begin{tabular}{|l|c|c|c|c|c|}
\hline $\begin{array}{l}\text { Complications of } \\
\text { obstructed labour }\end{array}$ & $\begin{array}{c}\text { Nyandarua } \\
(\mathbf{n = 2 1 )} \\
\%\end{array}$ & $\begin{array}{c}\text { Mwingi } \\
(\mathbf{n}=10) \\
\%\end{array}$ & $\begin{array}{c}\text { Kilifi } \\
(\mathbf{n}=\mathbf{1 2}) \\
\%\end{array}$ & $\begin{array}{c}\text { Taita Taveta } \\
(\mathbf{n}=13) \\
\%\end{array}$ & $\begin{array}{c}\text { Total } \\
(\mathbf{n}=56)\end{array}$ \\
\hline Rupture of uterus & 57 & 90 & 67 & 100 & 75 \\
\hline Obstetric fistula & 38 & 90 & 58 & 92 & 64 \\
\hline Intra-uterine fetal death & 90 & 90 & 92 & 100 & 93 \\
\hline Maternal death & 90 & 90 & 100 & 85 & 91 \\
\hline Total score $(0-4)$ & $\mathbf{2 . 8}$ & $\mathbf{3 . 6}$ & $\mathbf{3 . 2}$ & $\mathbf{3 . 8}$ & $\mathbf{3 . 2}$ \\
\hline
\end{tabular}

Despite the fact that it is common practice to use herbs during labour in Kilifi (FGDs), only 10 percent of the community midwives from the district said they would discuss the issue with pregnant women. However, it was noted that 80 percent of CMs said they advise against the "pushing of the abdomen during labour or childbirth (fundal pressure)".

\section{Community midwives can successfully manage obstructed labour}

The community midwives were only trained in the last 2 years and the available data was too small for analysis, however it was encouraging to note that $100 \%$ of the women received by the community midwives with a diagnosis of obstructed labour were promptly referred and none developed a fistula.

The following two narratives are indicative of how CMs successfully managed recent cases of obstructed labor in Nyandarua and Kilifi districts. In Nyandarua, the Community Midwifery programme started in 2006; the midwives have access to an ambulance, a mobile phone and the infrastructure is quite well developed. In Kilifi district, training of CMs started in early 2008 - 4 months before this assessment. The community midwives in Kilifi do not yet have access to an ambulance, and were yet to receive delivery kits and mobile phones.

\section{Case study 1 (Verbatim from Community Midwife): Nyandarua District}

"It was about 3.30am a fortnight ago when a woman called me to review her daughter. The client was 18 years old and had completed form two. This was her first pregnancy and she had not attended ANC at all as she had been sent away from home. After I interviewed and examined her, I found out that the fundal height was 38 weeks; the fetal heart rate was normal, presentation cephalic, engaged $1 / 5$ down and on vaginal examination her cervix was dilated at $9 \mathrm{~cm}$.

According to the client, she had started laboring more than 14 hours before they came for assistance. Vaginal examination revealed meconium stained liquor and she had strong contractions. I concluded that the client had obstructed labour. I telephoned a nurse from the government hospital to get an alternative view who concurred with my observations. We referred her to Nyahururu District Hospital for further review and management. We called the ambulance, which came immediately, and I accompanied them to the hospital. Before the ambulance arrived, I administered an intravenous infusion of 5 percent dextrose. The client underwent a successful caesarian section, and both mother and baby survived." 


\section{Case study 2: Kilifi District}

The client, an 18 years old primigravida, was taken to the CM after having labored for two days at home. After examination the CM found the mother was exhausted with low blood pressure and the birth canal was hot and dry. Foetal head palpation was high with rapid foetal heart. The $\mathrm{CM}$ asked the family members to prepare the client for emergency referral to Kilifi District Hospital for more specialized medical attention. The CM administered IV fluids prior to referral. The client was not able to give birth vaginally so a caesarian section was conducted. Both mother and child are doing well and are happy.

\section{Emerging issues when comparing the two case studies}

- Community members should refer women in labor to the CMs earlier before problems occur

- The CMs stabilized the clients prior to referral with IV fluids

- The district hospital in Nyandarua was able to send the ambulance on time, but the midwife in Kilifi district feels referral was delayed due to the lack of a dedicated 'obstetric' ambulance

- The client was attended to immediately when they (the community midwife and client) arrived at the hospital because the CM had notified the facility in advance

- Timely judgment and management by CMs resulted in safe delivery for both mother and baby

Almost all (except one) women referred for obstructed labour by CMs delivered through C/S.

\section{Facility-based health providers views on CMs}

Facility-based midwives agree that CMs have experience and capacity to diagnose obstetric complications and specifically prolonged/obstructed labour. They know CMs refer early and thereby more likely prevent obstructed labour and its sequalae. According to one of the health providers at Kilifi District hospital, some of the obstetric complications seen in Kilifi Hospital arrive in critical condition: ruptured uterus, mother with eclampsia who was fitting for two to three days. She feels that if the CMs are out there they can diagnose and refer early so that early appropriate action can be taken. Another provider has seen an increase in referrals from dispensaries and health centres that may be linked to CMs referring more women with complications. Health providers in Mwingi said they refer fistula cases to Garissa and Machakos Hospitals for treatment and care but only at certain times of the year. Most recently these took place in December 2007 and January 2008.

\section{Do women know of skilled providers in the community?}

In response to questions on the availability of skilled providers in the community 57 percent of women in both the OL and OF groups had heard of a trained person in the community who assists women during labour. It appears that community mobilization and raising awareness of CMs has been more effective in Taita Taveta than elsewhere (see Table 13).

Table 13: Women who have heard of a trained person in the community who assists at births

\begin{tabular}{|l|c|c|c|c|}
\hline Who is the trained person? & $\begin{array}{c}\text { Nyandarua } \\
(\mathbf{n}=\mathbf{3 4})\end{array}$ & $\begin{array}{c}\text { Mwingi } \\
(\mathbf{n}=\mathbf{4 2})\end{array}$ & $\begin{array}{c}\text { Kilifi } \\
(\mathbf{n}=\mathbf{3 9})\end{array}$ & $\begin{array}{c}\text { Taita Taveta } \\
(\mathbf{n}=\mathbf{3 6})\end{array}$ \\
\hline TBA & $12 \%$ & $14 \%$ & $44 \%$ & $31 \%$ \\
\hline Community Midwife & $9 \%$ & $26 \%$ & $13 \%$ & $53 \%$ \\
\hline Community Health Worker & $3 \%$ & $5 \%$ & $8 \%$ & $3 \%$ \\
\hline Have not heard & $74 \%$ & $55 \%$ & $36 \%$ & $11 \%$ \\
\hline
\end{tabular}


Most community members from the four districts were aware of the CMs who are attached to some health facilities and have received additional training; are recognized by the government and given equipment. They help deliver mothers and teach them how to take care during pregnancy. The CMs are more knowledgeable and experienced and likely to refer a client in time "...unlike TB As who would hold on a client arguing that she has delivered many women before therefore there is no problem even when foreseeing a complicated delivery". On the other hand some women in Taita Taveta were not aware of the CMs at all and only knew about TBAs. Others recognized that there were not enough CMs available or they may be expensive charging Kshs 1200 which may force some people to turn to the TBAs who are cheaper.

There remains some confusion regarding the role of the TBA and CHWs regarding skilled attendance at birth. When asked if there was a difference between a CM and a TBA, 74 percent of women from the OL group agreed with the statement compared to 53 percent of the OF group. Table 12 shows a summary of both men's and women's responses from the FGDs on the difference between TBA and CMs.

Table 12 Summary of community comments on the difference between a TBA and a CM

\begin{tabular}{|l|l|}
\hline TBAs & Community midwives \\
\hline $\begin{array}{l}\text { The TBAs don't use gloves when } \\
\text { delivering, and their hands could be dirty. } \\
\text { Some TBAs cut the cord with a panga. }\end{array}$ & $\begin{array}{l}\text { The CMs know about the many different diseases (like } \\
\text { AIDS). They also know how to care for a child so that it } \\
\text { is not infected with AIDS unlike the TBAs. Before, only } \\
\text { cutting the cord and tying it was the most important } \\
\text { thing to know how to do. }\end{array}$ \\
\hline $\begin{array}{l}\text { The TBAs just use their general } \\
\text { knowledge while the CM's have been } \\
\text { trained. So they are able to handle many } \\
\text { problems which the TBAs cannot handle. }\end{array}$ & $\begin{array}{l}\text { The CM handles clients if she can. Some women do } \\
\text { not tell their husbands immediately when they go into } \\
\text { labour. They wait until it is advanced. She (the CM) } \\
\text { sends the women who have delayed (labored for long) } \\
\text { to the hospital. }\end{array}$ \\
\hline $\begin{array}{l}\text { TBAs are uneducated. She does not know } \\
\text { how to handle and detect complications } \\
\text { and may abandon client when } \\
\text { complications arise. }\end{array}$ & $\begin{array}{l}\text { The CMs are able to detect key danger signs. } \\
\text { The CM refers complications immediately. }\end{array}$ \\
\hline $\begin{array}{l}\text { The TBA is not aware of the new and } \\
\text { modern knowledge. }\end{array}$ & $\begin{array}{l}\text { The CM has knowledge about HIV and knows how to } \\
\text { prevent infections like tetanus and HIV. }\end{array}$ \\
\hline
\end{tabular}

Among those women who knew about the CMs $(n=66)$, most had heard from someone in the community $(32 \%)$, followed by information received at church meetings $(20 \%)$, from a relative $(17 \%)$, at a health facility $(15 \%)$, from the CMs themselves $(6 \%)$ or their clients $(5 \%)$, were seen in the community $(5 \%)$ or heard about them on the radio $(2 \%)$.

Many women (72\%) said they would use a CM in the future. Almost four-fifths (79\%) of women said they would use community midwives because they were knowledgeable, skilled and accessible. However, 12 percent felt that facility services might be better than community services due to the challenge of handling complications. In comparing results across districts, over 70 percent of women from Mwingi, Kilifi and Taita Taveta had confidence in community midwifery services compared with 50 percent of women in Nyandarua district.

"The mothers like delivering at home with CMs because they will not ask you why you have too many children. The CM gives women food after delivery. She gives them tea. She also gives them warm water to wash themselves after delivery." (Female FGD respondent, Mwingi) 
All participants interviewed (i.e., men, women, facility-based health providers) agree that CMs do have the skills to assist women during childbirth especially if they were linked to health facilities in case of emergency. I would go to the CM's because she knows me and my wife personally. Unlike the doctors, she would also cooperate with doctors'. (Male respondent)

Findings from both the male and female FGDs show that community based professional services for women and children were in demand. The general consensus was that the government should provide the equipment and supplies and even pay them some token to encourage them to offer their services. The community members felt that CMs should be given opportunities to sensitize the community at health facilities so that women and their families know where to find them and seek their services during the early stages of labour so that a proper assessment can be made as to the best place to deliver. Some of the health providers believed that the CMs need a stipend for supervision and bringing the reports. Community members felt that the government should also take responsibility for paying for their services. CMs should wear badges so that everyone knows who they are.

\section{Emerging solutions from the community}

- More CMs need to be trained

- Increase the number of health facilities or the capacity of existing health facilities

- Build more roads/provide referral vehicles

- Financial empowerment of women to reduce dependence on men

- Health education to improve health seeking behaviour

- Practice family planning

- Improve quality of services in existing health facilities

- Avoid TBA services

- Reduce the cost of health services

- Hospitals should maintain high levels of hygiene to avoid infections at the ward

\section{Transport and Referrals}

The road infrastructure is poor in all districts and particularly bad in the rainy season especially when roads flood and women are unable to reach any health facilities. One respondent said, 'everything comes to a balt.' Distances are also great. The most frequently used means of transport for clients during an emergency, according to the CMs, is as follows: Ambulance (44 percent), Matatu (38 percent), Private car (31 percent), bicycle/ trailer ambulance (15 percent), cart or bicycle (6 percent), no transport (11 percent). Only four out of $13 \mathrm{CMs}$ in Taita Taveta said there was no transport to use.

Mwingi and Nyarahuru districts have an ambulance that midwives can call in case of an emergency. The District Health Administration Officer is responsible for fueling the vehicle and ensuring its availability at weekends and overnight. There are ambulances in Kilifi - but the $\mathrm{CMs}$ have more problems contacting them. Health providers in Kilifi recommend that the CMs call the ambulance but then the CM escorts the women to a nearby health facility or easily recognized place for easier collection. Some areas are almost inaccessible. In Nyandarua, CM referrals took between 20 minutes to one and half hours to reach the hospital. The CM either escorted the woman to the hospital or informed the hospital in advance. Taxis and private cars (were more frequently used than the ambulance) some CMs use bicycle to transport women to hospital.

The challenges in preventing and managing obstetric fistula are many and varied. However none of them should be insurmountable given the level of knowledge or awareness provided by the community interviews. Health providers are also aware of ways to improve health outcomes. 
Table 13 describes a summary of views from health care providers working in the hospitals and health facilities in the four districts.

\section{Table 13 Summary of views from health care providers}

\section{Prevention of Fistula \\ Management of Obstetric Fistula}

\section{Capacity strengthening}

- Increased emphasis on prevention

- Upgrade periphery health facilities with equipment, supplies and staffing

- Strengthening delivery by skilled personnel - Proper management of labor: emphasis on use of the partograph to detect prolonged labor; early intervention in poor progressing labour; prompt action when obstructed labor is diagnosed

- Refresher courses for doctors, midwives and interns on handling mothers with obstructed labour and prevention of fistula

- All patients with prolonged labor to have a catheter in situ

- Increase midwife-client ratio in the ward

- Train more community midwives including from other districts that may refer to hospitals

- Train more community midwives to ease the referral of mothers

\section{Community mobilization}

- Disseminate the most important information and communication on behavior change.

- Health workers co-ordinate with community leaders to educate the mothers on importance of ANC attendance and need for skilled care at birth

- Health education to mothers on seeking medical attention immediately

- Discourage the community from FGM and early marriages

- Target youth to delay first birth

- Empowering communities and women through education

\section{Poverty}

- Reduce hospital charges that put mothers off from going to hospital for delivery

\section{Communication and referral}

- Improve infrastructure (roads) - transport is the main cause of delay in referral

- Improve referral systems from dispensaries and HCs to hospitals.

- Community ambulance be stationed in the periphery health facilities other than at the district hospital for quicker referral
- All labor ward staff must be taught about early management of VVF

- Provision of complete VVF sets/equipment, e.g. adjustable mobile theater tables

- Decentralization of treatment and care of obstetric fistula to district hospitals to make services more accessible

- Train more staff in more facilities on OF treatment and care

- Every gynecologist should be trained on VVF treatment and care

- Have some dedicated centers to manage and treat fistulas to enhance skill development, research and total care of the patients including physiotherapy, psychotherapy and rehabilitation

- Proper psychological and counseling care: early management and treatment and care to avoid psychological trauma

- Improve infection prevention to avoid breakage and prolonged hospital stay

- Ensure women and communities are aware of where to seek assistance for fistula treatment and care

- Complete waiver system for OF clients

- Improve infrastructure and referral system

- Checking the referral system process, so as to ensure mothers with VVF are referred straight to a facility that treatment and cares rather than having to pass through all levels 


\section{DISCUSSION}

This study assesses the obstetric fistula and community midwifery initiatives in four districts in Kenya supported by UNFPA. The study documents the experiences of women affected by obstructed labour and obstetric fistula. In addition it elicits community perceptions and responses to these issues and describes whether the community midwifery initiative has the potential to make a difference in combating the devastating effects of obstetric fistula.

Since 2003, following the launch of the end fistula campaign, the Ministry of Health, UNFPA and partners have increased the focus on treating and caring for more women living with fistula. Many more hospitals, physicians and specifically trained teams are able to provide these services, including reducing the costs on the women's side. Most of the women interviewed had received treatment and care within the last two years. However there are still gaps in successfully treating fistula. Some of the hospitals reviewed had either trained surgeons but incomplete equipment, or insufficient personnel but complete equipment.

Evidence from the literature, within the region, states that nine out of ten women undergoing fistula surgery are repaired successfully. This is at the time of discharge since women are not necessarily followed up long term. Just over two-thirds $(72 \%)$ of the women interviewed for this study had surgery. Of these two-thirds of the women say they are now completely dry. More emphasis must be put on care and follow up of women after fistula treatment and care including rehabilitation and reintegration into their communities.

Many women are living in poverty, in rural places with poor road infrastructure and transport options. Moreover this study supports the literature in that women are more likely to develop fistula if they and their husbands have had no or limited education, are in a polygamous union, and where the husband is more than 10 years older than the woman. Their sexual debut is more likely to be earlier (average of 17 years) and to get pregnant earlier. Poor health seeking behaviour, limited knowledge of danger signs and stagnation of skilled attendance at birth may be attributable to intangible cultural factors that cannot be explained by access or awareness of complications around pregnancy and childbirth.

Husbands are often blamed for long and difficult labour and their absence from home contributes to delays in deciding to seek care when complications arise. Women are often comfortable with traditional birth attendants and cultural roles they fulfill, but the evidence from this study shows that women are more likely to get fistula if they are attended by an unskilled person. The case histories bear testimony to this. In Western Province where community midwives were originally introduced, a number of the more successful CMs have been able to work in partnership with the TBAs. Some TBAs are involved in identifying pregnant women in a given area and support the $\mathrm{CM}$ during the labour acting as the companion to the women in labour.

Nevertheless this study demonstrates that many community members are indeed aware of the risks associated with pregnancy and childbirth, and the need to ensure women have access to skilled care. Each district in this study has trained a number of community midwives in the last two years. The findings from the FGDs show that CMs and community-based services are in demand. Although they are generally 'too few', all are regarded as a welcome resource in supporting women in childbirth. This is especially so where the CMs have good links with referral facilities and availability of transport options.

The community midwifery initiative has demonstrated in both Western province and the four UNFPA districts that it is feasible, acceptable and effective. The challenge is now consolidating and scaling up the number of available CMs. However it is important that all CMs should receive 
the necessary seed equipment at the time they complete their training as well as refresher updates in management of maternal complications. While all CMs referred women in prolonged labour in time, gaps in knowledge do exist. However these gaps in knowledge are no different to gaps in knowledge among service providers working within health facilities. Continuous technical updates for maternity staff are also necessary.

For the sustainability of the CM initiative, and while the issue of payment of community health extension workers is under review, the introduction of a two-day business skills workshop goes a long way to support the CM provide her essential services. After the business training in Western Province it was clear that the revenue collected was adequate to sustain the services and generate income for the CMs (Mwangi and Warren 2008).

\section{RECOMMENDATIONS}

The Ministry of Public Health and Sanitation and the Ministry of Medical Services have identified MNH as a priority. In line with the strategies outlined in the Kenya MNH road map for the acceleration in the reduction of maternal and newborn morbidity and mortality (2008) and other national policy documents these recommendations are focused at preventing obstetric fistula and scaling up treatment and care for women living with OF. A particular emphasis is on districts where skilled attendant rates are low and poor health seeking behaviour for obstetric complications. In summary the key recommendations emerging from this report are: to update health facility midwives in MNH skills including prevention, treatment and care of obstetric fistula; train more community midwives; increase community awareness; listen to men and women and involve them in community health committees and district health plans for improving $\mathrm{MNH}$ taking into account cultural sensitivities.

Detailed activities regarding the recommendations are outlined at four different levels: the community, the linkages between community and health services, the health facility and the policy level. These should be reviewed and incorporated into annual operational plans:

\section{Home, family and community level}

- Encourage women and families to make birth plans, educate on pregnancy and childbirth related problems and encourage them to seek care early for obstetric complications.

- Instigate financial literacy activities including saving mechanisms and income generating schemes: encourage families to enroll in health insurance schemes such as NHIF, KWFT, Equity bank, Faulu, K-rep etc. Scale up OBA/DSF according to GOK guidelines.

- Through the CMs, Community Health Committees and barazas develop specific messages for obstetric complications and $\mathrm{OF}$ in local language and use multi-channel distribution; address cultural practices that negatively impact on maternal and newborn health.

- Encourage fistula survivors to be advocates at community level.

- Develop advocacy messages with community about risks of pregnancy and childbirth.

- Expand the number of community midwives and their mandate. 
- Encourage male involvement in birth planning and emergency preparedness (e.g., decisions, fees, transport, and identification of a birth companion). Encourage open discussions about maternal health between men and women so it is no longer 'just a woman's issue'.

- Develop mechanisms for data collection at community level for all pregnant women and women with OF for easy follow-up and care.

\section{Linkages between community and health services}

- Strengthen referral system:

- Procure more ambulances / motorcycle ambulances;

- Ambulances should be distributed evenly across the districts in strategically placed health facilities, not all at district hospital. Drivers should be on call 24/7.

- Develop / strengthen district wide transport schemes: Agreement with private care owners/matatus

- Build more maternity waiting homes adjacent to hospitals where distances are great

- Regular supervision and incentives for CMs and community health workers

- Improve rehabilitation and reintegration of fistula clients link to social support programs

\section{Quality of care in health facilities:}

- Strengthen maternity services at all levels:

- Ensure essential equipment, drugs and supplies

- Upgrading of existing facilities to provide quality maternity care and treatment and care for fistula nearer to where women live;

- Improve client waiting times

- Strengthen in-service and pre-service training, supervision and quality assurance

- Improve provider attitudes and moral

- Regular updates in essential obstetric care updates

- Emphasize prevention of OF, use partograph for every labour, use of indwelling catheters, close follow up.

- Adequate staffing and skills mix in health facilities and accountability of health providers

- Clinical audits and mortality audits for mothers, newborns and stillbirths

- Introduce use of intra-partum case fatality rate - which is defined as the proportion of deliveries that result in late stillbirths and early neonatal deaths in a given health facility

\section{- To address the 'backlog' of women living with fistula:}

- Train more fistula teams (nurses, doctors theatre staff, physiotherapists and social workers) at district level: all medical officers/gynecologists should be able to provide treatment and care for fistula

- Disseminate evidence based guidelines/standards at local levels

- Ensure sufficient equipment is available where staffing for treatment and care exists

- Following treatment and care efforts continue to rehabilitate and re-integrate women back into their communities 


\section{Policy level}

- Output based financing: subsidize maternal health care services and RH commodities; consider free C/S for obstetric emergencies and OF treatment and care (voucher based reimbursement). MOPHS and MOMS are currently reviewing OBA/DSF to target poor women

- Lobby Parliamentarian Health Committee to raise awareness of OF at national level

- Review the use of motorcycle ambulances for referral : four motorcycles provide the equivalent transport as one land cruiser ambulance

- In implementing the Community Strategy, design effective training packages for all community health workers (including TBAS) with clear roles and responsibilities; provide on-going supervision and refresher training for providers in the community 


\section{REFERENCES}

\section{(See Appendix 3 for details)}

AbouZahr, Carla \& Tessa Wardlaw, Maternal mortality at the end of a decade: signs of progress? Bulletin of the World Health Organization, 2001, 79 (6)

Ahmed (2007) Dead women walking: neglected millions with Obstetric fistula. International Journal of Gynecology and Obstetrics (2007) 99, S1 - S3

Ahmed Holtz and Stanton (2007) Challenges in measuring obstetric fistula International journal of Gynecology and Obstetrics (2007) 99 S4-S9)

Chilopora and Rijken (2007) Urogenital and recto-vaginal fistulas in Southern Malawi: A report on 407 patients. International Journal of Gynecology and Obstetrics (2007) 99, S85 - S89

Creanga, Genardry et al (2007) Complex obstetric fistulas, International Journal of Gynecology 99, S51-556 International Federation of Gynecology and Obstetrics. Published by Elsevier Ireland Ltd.

Dolea and Abouzahr

Donnay F. Ramsey K. (2006) Eliminating obstetric fistula: progress in partnerships. International Journal of Gynecology and Obstetrics 94, $254-261$.

Graham, W., J. S. Bell, and H. W. Bullough. (2001). "Can Skilled Attendance at Delivery Reduce Maternal Mortality in Developing Countries?” Pp. 97-129 in: Safe Motherhood Strategies: A Review of the Evidence, by V. De Brouwere and W.Van Lerberghe. 2001. Studies in Health Services Organisation and Policy Series. No 17. Antwerp: ITG Press.

Johnson R.H (2007) Incontinence in Malawi: analysis of a proxy measure of vaginal fistula in national survey. International Journal of Gynecology and Obstetrics (2007) 99, S122 - S129

Khalil Karima and Farzaneh Roudi-Fahimi. (2004). Making Motherhood Safer in Egypt Population Reference Bureau.

Lassey AT. Simple fistulas: Diagnosis and management in low-resource settings -A descriptive report

International journal of gynecology and obstetrics (2007) 99,547-550 International Federation of Gynecology and Obstetrics. Published by Elsevier Ireland Ltd.

Mabeya et al (2007) Characteristics of women admitted with obstetric fistula in the rural hospitals in West Pokot, Kenya

Macdonald P. and Stanton M.E. (2007) USAID programme for the Prevention and Treatment of Vaginal Fistula US Agency for International Development, Washington, DC, USA International journal of gynecology and obstetrics International Federation of Gynecology and Obstetrics. Published By Elsevier Ireland Ltd

Madan K. Manandhar, Hilary Standing, Sharma S. Manandhar and Anthony M de L Costello Id21 health communicating development research http://www.id21.org/health Accessed 14 May 2003. 
Ministry of Health and Population Council. (2007). Community Midwifery Implementation Guidelines.

Ministry of Health Taking KEPH to the Community- A Strategy for Level One Services MOH. (2006).

Mohammed R.H. (2007) A community program for women's health and development: Implications for the long-term care of women with fistulas International Journal of Gynecology and Obstetrics (2007) 99 S137-S142

Mwangi, A and Warren C. (2008) Taking Critical Services to the Home: Scaling-up Home-based Maternal and Postnatal Care, including Family Planning, through Community Midwifery in Kenya, FRONTIERS, Population Council

Ojengbede et al (2007) Local anesthesia: an appropriate technology for simple fistula repair. International Journal of Gynecology and Obstetrics (2007) 99, S75 - S78

International Federation of Gynecology and Obstetrics. Published by Elsevier Ireland Ltd.

Rumbold, T. and Warren, C. (2006). A review of the community midwifery model in western Kenya, Population Council.

Thaddeus and Maine (1994) Too Far to Walk: Maternal Mortality in Context. Social Science and Medicine 38 (8):1091 -1110

UNFPA 2004 fistula fact sheet http://kenya.unfpa.org/fistula fact.htm downloaded 10th April 2008

Van Lerberghe, W. De Brouwere, V. (2001). Of Blind Alleys and Things that have Worked: History's Lessons on Reducing Maternal Mortality Safe Motherhood Strategies: a review of the evidence. Studies in Health Services Organisation and Policy, 17

Wall L.L. Where should obstetric vesico - vaginal fistulas be repaired: at the district general hospital or a specialized fistula center? International Journal of Gynecology and Obstetrics (2007) 99, S28 - S31

WHO (2005) The World Health Report: 2005: Make Every Mother and Child Count. WHO Geneva

www.endfistula.org 


\section{Appendix 1: Research Methodology}

\section{Specific Aims}

The specific aims of this study were to:

1. Assess the capacity of districts to manage obstetric complications including obstetric fistula;

2. Determine the extent of obstetric fistula in selected districts;

3. Identify factors that impede women accessing care during pregnancy, labour, childbirth and the postnatal period among those women who have experienced obstetric fistula;

4. Determine the role of $\mathrm{CM}$ in addressing the factors identified above;

5. Identify interventions including development of advocacy materials;

6. List essential equipment for treatment and care of $\mathrm{OF}$

\section{Subject population and recruitment}

The main study population comprised of two groups: 1) women affected by fistula or obstructed labour and 2) health care providers. A representative sample was selected of women living with obstetric fistula and/or those women who have had treatment and care of fistula and were willing and able to talk about their experiences. The participants were identified and recruited through hospitals records. In addition women were also identified through the community midwives working in the selected districts.

A retrospective review of hospital operating theater registers and case notes from January to April 2008 was carried out. Physical and telephone contacts for OF survivors were identified. The public health officers in Ministry of Health were very helpful during the mapping to trace the women in their homes.

\section{In-depth interviews with women}

The interviews with women affected by obstetric fistula incorporated structured questions as well as an in-depth review of the events leading up to the fistula developing. In order to reduce the potential distress during the interviews with women affected by obstetric fistula, the research assistants were experienced nurse midwives with training in counselling and research methods. All the midwives had recognized certificates or diplomas in counselling.

Appointments with respondents were made for the interview. Women were invited to attend for an interview by the hospital; the health provider initiated discussion around the possibility of being interviewed and subsequently introduced the woman to a member of the research team. If the woman was happy to be interviewed there and then the interview continued after the informed consent has been signed. Otherwise the interview time and setting was agreed upon between the research assistant and respondents. The interview took place at the health facility in a room(s) specifically set aside for the research teams. Or alternatively the interview was carried out at the informants' place of choice: for example, outside the facility in the grounds (under a tree), at the woman's home or at a friend's home. At all times privacy and confidentiality were of paramount importance. -The research assistants also provided the respondents referral letters for relevant follow up services to the gynaecologist of nearest hospitals or to one of the designated OF treatment and care centres where doctors are specifically trained in management and treatment and care of obstetric fistula (Mombasa, Nairobi and Machakos hospitals). In total 82 women were interviewed.

In addition women who attended facilities during the study period with obstructed labour but did not complicate to obstetric fistula were also interviewed. This was done to compare the health 
seeking behaviour between those that sought EmOC early and those that did not and resulted in obstetric fistula.

Demographic data included social, economic and health indicators pertinent to the study. Key health indicators: age at marriage, age at first pregnancy, care received during pregnancy, labour childbirth and the postnatal period, details of the fistula occurring, and the woman's living situation following the fistula. We investigated what are the social and economic determinants that may increase risk of fistula to try to identify fistula and social vulnerability.

Resumption of sexual activity since OF treatment and care and her fertility intentions, use of family planning and any subsequent pregnancies following treatment and care.

Experience since the fistula treatment and care: how has this changed, how does she take care of herself now? What is life like now she is back home and dry? Where does she live? Reintegration into family life and the community: Does she want to marry again? Is her husband still around? How did he react and will he respond to her return? How was she able to reintegrate into the community? Has she returned to the same situation?

The research assistants were trained for eight days: three days on counselling techniques for this particular group of women and five days for understanding the instruments to be used.

Provider interviews with health, providers from health facilities visited and community midwives were conducted to determine the opportunities and challenges in sustaining the $\mathrm{CM}$ initiative, as well as their perceptions and support for community midwifery services, and understanding of the organizational set up. Interviews also tried to ascertain their perceptions of barriers and operational challenges that may influence clients' acceptance of home deliveries and postnatal visits, and the providers' attitudes towards the changes in policy and procedures needed to provide the new package of care. Midwives were asked questions on their knowledge and skills in managing prolonged or obstructed labour and whether they know where to refer women suffering from obstetric fistula. 56 health services providers were interviewed.

Focus group discussions: Where the community midwives reside in a given geographic area, contact was made with users and none users of the $\mathrm{CM}$ services and their spouses. Women were traced through community midwifery records and discussions with the government administration that is the chief/sub chief for that location. Information on the specific days and timing for such meetings inviting relevant people to attend discussion groups were broadcasted during the chief's weekly community meetings (barazas). These women and men were requested to attend focus group discussions to determine the perceptions and support of the services and acceptability of community midwifery services as well as their understanding of the organizational set up. Discussions aimed to ascertain both women and men's perceptions of barriers and operational challenges that may influence clients' and their families' acceptance of home deliveries, health seeking behaviour during pregnancy and childbirth, and postnatal care. Two FGDs each for both men and women were carried out in each district. The researchers requested discussants whether they could use tape recorders to record the discussions, which were transcribed shortly afterwards. The tapes were kept under lock and key until destroyed before the end of the project (July 2008).

A district/hospital capacity tool for providing services for OF was sent to the relevant MOH staff to find out the current situation. Health service managers were requested to fill this form prior to the research team visiting the hospital. Any gaps in information were then filled while the research team was at the hospital. 
Service utilization data from facility records was also reviewed to assess the number of women attending for ANC and delivery, including a review of registers for obstetric complications and specifically obstructed labour and ruptured uterus. In addition case histories were extracted from in patient notes for women who had experienced obstructed/prolonged labour.

A desk review of obstetric fistula programs and documents was undertaken to determine the content and the extent to which they facilitate or influence the provision of information and services to women affected by obstetric fistula. See Appendix 5.

The following table outlines the questionnaires and number of interviews/reviews that took place.

Total Number of Interviews

\begin{tabular}{|l|l|l|l|l|l|}
\hline \multirow{2}{*}{ Type of questionnaire: } & Districts & \multicolumn{4}{l|}{} \\
\cline { 2 - 6 } & Nyandarua & Mwingi & Kilifi & Taita Taveta & Total \\
\hline Women with Obstructed labour & 25 & 16 & 7 & 22 & 70 \\
\hline Women with Obstetric fistula & 9 & 26 & 33 & 14 & 82 \\
\hline Community Midwives & 12 & 10 & 14 & 13 & 56 \\
\hline $\begin{array}{l}\text { Record review of clients with obstructed } \\
\text { labour }\end{array}$ & 12 & 10 & 14 & 15 & 51 \\
\hline Hospital capacity to provide repairs of OF & 2 & 1 & 1 & 3 & 7 \\
\hline FGDs with women in community & 2 & 2 & 2 & 2 & 8 \\
\hline FGDs with men in community & 2 & 2 & 2 & 2 & 8 \\
\hline Group discussions with health providers & 1 & 1 & 1 & 1 & 4 \\
\hline
\end{tabular}




\section{Data analysis}

The quantitative data generated from the survey was analyzed using the SPSS computer package using descriptive statistics and reported in the form of frequencies, cross tabulations, and percentages.

Analysis of the qualitative data involved thematic analysis in which data are categorized along identified themes and patterns. The data collected through in-depth interviews and group discussions will be analyzed using the thematic approach. The observation data will be categorized and analyzed in the form of indices, which will be constructed based on the parameters observed during the study.

The second stage of qualitative analysis was done using the QSR NUD*IST software program. The software permits the organization and analysis of data from different sources through an index coding system. Initially the data, comprised of themes and indices, was entered into a word processor in a format acceptable to the NUD*IST program. The data was then was imported into the program and an index coding system developed. Using the program, an integrated analysis of data collected using different methods was performed.

Structured questionnaires were used for data collection from facility records, community midwives and women who have experienced prolonged/obstructed labour and obstetric fistula, these questionnaires solicited for closed and short open-ended responses. Data ware entered into databases designed using EpiData with inbuilt validation rules to ensure the validity of responses entered. A double-entry approach was used with the two sets of entries compared; verification and correction of erroneous entries followed whenever the two sets of entries didn't match. After ensuring that the two datasets matched perfectly, data were exported into SPSS which was used to produce descriptive statistics (to measure frequencies, central tendency and dispersion) for all responses. New variables have been computed to aggregate responses and calculate scores to be used in assessing various indicators. 


\section{Appendix 2: Comparison of general characteristics of women by District and}

OF status

\begin{tabular}{|c|c|c|c|c|c|c|c|c|c|c|c|c|c|c|c|c|}
\hline \multirow{3}{*}{ Women who: } & \multicolumn{4}{|c|}{ Nyandarua } & \multicolumn{4}{|c|}{ Mwingi } & \multicolumn{4}{|c|}{ Kilifi } & \multicolumn{4}{|c|}{ Taita Taveta } \\
\hline & \multicolumn{2}{|c|}{ OL } & \multicolumn{2}{|c|}{ OF } & \multicolumn{2}{|c|}{ OL } & \multicolumn{2}{|c|}{ OF } & \multicolumn{2}{|c|}{ OL } & \multicolumn{2}{|c|}{ OF } & \multicolumn{2}{|c|}{ OL } & \multicolumn{2}{|c|}{ OF } \\
\hline & $\%$ & $\mathbf{N}$ & $\%$ & $\mathbf{N}$ & $\%$ & $\mathbf{N}$ & $\%$ & $\mathbf{N}$ & $\%$ & $\mathbf{N}$ & $\%$ & $\mathbf{N}$ & $\%$ & $\mathbf{N}$ & $\%$ & $\mathbf{N}$ \\
\hline
\end{tabular}

\section{General characteristics:}

\begin{tabular}{|c|c|c|c|c|c|c|c|c|c|c|c|c|c|c|c|c|}
\hline Attended school & 100 & 25 & 100 & 9 & 100 & $\begin{array}{l}1 \\
6\end{array}$ & 46 & 26 & 57 & 7 & 58 & 33 & 95 & $\begin{array}{l}2 \\
2\end{array}$ & 79 & 14 \\
\hline $\begin{array}{l}\text { Could read } \\
\text { fluently in both } \\
\text { English and } \\
\text { Kiswahili }\end{array}$ & 88 & 24 & 56 & 9 & 69 & $\begin{array}{l}1 \\
6\end{array}$ & 31 & 26 & 43 & 7 & 39 & 33 & 73 & $\begin{array}{l}2 \\
2\end{array}$ & 43 & 14 \\
\hline $\begin{array}{l}\text { Could read } \\
\text { fluently only in } \\
\text { Kiswahili }\end{array}$ & 4 & 24 & 0 & 9 & 13 & $\begin{array}{l}1 \\
6\end{array}$ & 0 & 26 & 0 & 7 & 0 & 33 & 18 & $\begin{array}{l}2 \\
2\end{array}$ & 14 & 14 \\
\hline $\begin{array}{l}\text { Could read part } \\
\text { of sentence in } \\
\text { English }\end{array}$ & 4 & 24 & 22 & 9 & 6 & $\begin{array}{l}1 \\
6\end{array}$ & 4 & 26 & 0 & 7 & 3 & 33 & 0 & $\begin{array}{l}2 \\
2\end{array}$ & 0 & 14 \\
\hline $\begin{array}{l}\text { Could read part } \\
\text { of sentence in } \\
\text { Kiswahili }\end{array}$ & 4 & 24 & 0 & 9 & 0 & $\begin{array}{l}1 \\
6\end{array}$ & 4 & 26 & 0 & 7 & 12 & 33 & 0 & $\begin{array}{l}2 \\
2\end{array}$ & 0 & 14 \\
\hline $\begin{array}{l}\text { Could not read } \\
\text { in either English } \\
\text { or Kiswahili }\end{array}$ & 0 & 24 & 22 & 9 & 13 & $\begin{array}{l}1 \\
6\end{array}$ & 61 & 26 & 57 & 7 & 46 & 33 & 9 & $\begin{array}{l}2 \\
2\end{array}$ & 43 & 14 \\
\hline $\begin{array}{l}\text { Completed } 8 \\
\text { year primary } \\
\text { education }\end{array}$ & 48 & 25 & 0 & 9 & 44 & $\begin{array}{l}1 \\
6\end{array}$ & 25 & 12 & 25 & 4 & 16 & 19 & 33 & $\begin{array}{l}2 \\
1\end{array}$ & 18 & 11 \\
\hline $\begin{array}{l}\text { Completed } 4 \\
\text { year secondary } \\
\text { education }\end{array}$ & 16 & 25 & 22 & 9 & 6 & $\begin{array}{l}1 \\
6\end{array}$ & 0 & 12 & 50 & 4 & 5 & 19 & 30 & $\begin{array}{l}2 \\
0\end{array}$ & 0 & 11 \\
\hline $\begin{array}{l}\text { Are currently } \\
\text { working }\end{array}$ & 60 & 25 & 44 & 9 & 19 & $\begin{array}{l}1 \\
6\end{array}$ & 27 & 26 & 57 & 7 & 67 & 33 & 36 & $\begin{array}{l}2 \\
2\end{array}$ & 36 & 14 \\
\hline $\begin{array}{l}\text { Earn less than } \\
\text { Kshs } 2000\end{array}$ & 0 & 15 & 50 & 4 & 0 & 3 & 43 & 7 & 25 & 4 & 41 & 22 & 0 & 8 & 25 & 4 \\
\hline $\begin{array}{l}\text { Earn less than } \\
\text { Kshs } 5000\end{array}$ & 40 & 15 & 50 & 4 & 100 & 3 & 57 & 7 & 50 & 4 & 32 & 22 & 50 & 8 & 75 & 4 \\
\hline Live with partner & 100 & 21 & 75 & 4 & 85 & $\begin{array}{l}1 \\
3\end{array}$ & 73 & 11 & 83 & 6 & 79 & 19 & 75 & $\begin{array}{l}1 \\
6\end{array}$ & 100 & 5 \\
\hline $\begin{array}{l}\text { Has/had co- } \\
\text { wife/wives }\end{array}$ & 9 & 22 & 29 & 7 & 0 & $\begin{array}{l}1 \\
1\end{array}$ & 40 & 20 & 33 & 6 & 34 & 32 & 22 & $\begin{array}{l}1 \\
8\end{array}$ & 45 & 11 \\
\hline Are divorced & 4 & 25 & 0 & 9 & 0 & $\begin{array}{l}1 \\
6\end{array}$ & 4 & 26 & 0 & 7 & 9 & 33 & 0 & $\begin{array}{l}2 \\
2\end{array}$ & 14 & 14 \\
\hline Are separated & 0 & 25 & 22 & 9 & 0 & $\begin{array}{l}1 \\
6\end{array}$ & 12 & 26 & 0 & 7 & 18 & 33 & 9 & $\begin{array}{l}2 \\
2\end{array}$ & 14 & 14 \\
\hline
\end{tabular}

At the time of first marriage:

\begin{tabular}{|c|c|c|c|c|c|c|c|c|c|c|c|c|c|c|c|c|}
\hline $\begin{array}{l}\text { Were older than } \\
\text { husband }\end{array}$ & 4 & 22 & 0 & 7 & 0 & $\begin{array}{l}1 \\
3 \\
\end{array}$ & 5 & 20 & 0 & 6 & 0 & 32 & 0 & $\begin{array}{l}1 \\
8 \\
\end{array}$ & 0 & 12 \\
\hline $\begin{array}{l}\text { Were same age } \\
\text { as husband }\end{array}$ & 14 & 22 & 0 & 7 & 8 & $\begin{array}{l}1 \\
3 \\
\end{array}$ & 5 & 20 & 17 & 6 & 34 & 32 & 22 & $\begin{array}{l}1 \\
8 \\
\end{array}$ & 33 & 12 \\
\hline $\begin{array}{l}\text { Were younger } \\
\text { than husband by } \\
<10 \text { years }\end{array}$ & 73 & 22 & 71 & 7 & 77 & $\begin{array}{l}1 \\
3\end{array}$ & 60 & 20 & 17 & 6 & 13 & 32 & 56 & $\begin{array}{l}1 \\
8\end{array}$ & 25 & 12 \\
\hline $\begin{array}{l}\text { Were younger } \\
\text { than husband by } \\
>10 \text { years }\end{array}$ & 9 & 22 & 0 & 7 & 15 & $\begin{array}{l}1 \\
3\end{array}$ & 30 & 20 & 50 & 6 & 53 & 32 & 22 & $\begin{array}{l}1 \\
8\end{array}$ & 42 & 12 \\
\hline $\begin{array}{l}\text { Don't know if } \\
\text { younger or older } \\
\text { than husband }\end{array}$ & 0 & 22 & 29 & 7 & 0 & $\begin{array}{l}1 \\
3\end{array}$ & 0 & 20 & 17 & 6 & 0 & 32 & 0 & $\begin{array}{l}1 \\
8\end{array}$ & 0 & 12 \\
\hline
\end{tabular}




\begin{tabular}{|c|c|c|c|c|c|c|c|c|c|c|c|c|c|c|c|c|c|}
\hline \multirow{3}{*}{\multicolumn{2}{|c|}{ Women who: }} & \multicolumn{4}{|c|}{ Nyandarua } & \multicolumn{4}{|c|}{ Mwingi } & \multicolumn{4}{|c|}{ Kilifi } & \multicolumn{4}{|c|}{ Taita Taveta } \\
\hline & & \multicolumn{2}{|c|}{$\mathrm{OL}$} & \multicolumn{2}{|c|}{ OF } & \multicolumn{2}{|c|}{$\mathrm{OL}$} & \multicolumn{2}{|l|}{ OF } & \multicolumn{2}{|c|}{$\mathrm{OL}$} & \multicolumn{2}{|l|}{ OF } & \multicolumn{2}{|c|}{$\mathrm{OL}$} & \multicolumn{2}{|l|}{ OF } \\
\hline & & $\%$ & $\mathbf{N}$ & $\%$ & $\mathbf{N}$ & $\%$ & $\mathbf{N}$ & $\%$ & $\mathbf{N}$ & $\%$ & $\mathbf{N}$ & $\%$ & $\mathbf{N}$ & $\%$ & $\mathbf{N}$ & $\%$ & $\mathbf{N}$ \\
\hline \multicolumn{18}{|c|}{ At the time of first pregnancy: } \\
\hline $\begin{array}{l}\text { Wanted to hav } \\
\text { baby at that tim }\end{array}$ & & 68 & 25 & 67 & 9 & 56 & $\begin{array}{l}1 \\
6 \\
\end{array}$ & 54 & 26 & 72 & 7 & 61 & 33 & 50 & $\begin{array}{l}2 \\
2 \\
\end{array}$ & 57 & 14 \\
\hline $\begin{array}{l}\text { Wanted to hav } \\
\text { baby later }\end{array}$ & & 16 & 25 & 0 & 9 & 38 & $\begin{array}{l}1 \\
6\end{array}$ & 23 & 26 & 14 & 7 & 24 & 33 & 23 & $\begin{array}{l}2 \\
2\end{array}$ & 14 & 14 \\
\hline $\begin{array}{l}\text { Did not want to } \\
\text { have baby at a }\end{array}$ & & 16 & 25 & 33 & 9 & 6 & $\begin{array}{l}1 \\
6 \\
\end{array}$ & 23 & 26 & 14 & 7 & 15 & 33 & 27 & $\begin{array}{l}2 \\
2 \\
\end{array}$ & 29 & 14 \\
\hline \multicolumn{18}{|c|}{ ANC attendance for first pregnancy: } \\
\hline $\begin{array}{l}\text { Attended } \\
\text { ANC in first } \\
\text { pregnancy }\end{array}$ & 96 & & $\begin{array}{l}2 \\
5\end{array}$ & 67 & 9 & 94 & $\begin{array}{l}1 \\
6\end{array}$ & 65 & $\begin{array}{l}2 \\
6\end{array}$ & 100 & 7 & 73 & 33 & 91 & $\begin{array}{l}2 \\
2\end{array}$ & 86 & $\begin{array}{l}1 \\
4\end{array}$ \\
\hline $\begin{array}{l}\text { Attended } \\
\text { ANC in first } \\
\text { pregnancy - } \\
4 \text { times }\end{array}$ & 71 & & $\begin{array}{l}2 \\
4\end{array}$ & 67 & 6 & 53 & $\begin{array}{l}1 \\
5\end{array}$ & 47 & $\begin{array}{l}1 \\
7\end{array}$ & 86 & 7 & 79 & 24 & 60 & $\begin{array}{l}2 \\
0\end{array}$ & 67 & $\begin{array}{l}1 \\
2\end{array}$ \\
\hline $\begin{array}{l}\text { Age at first } \\
\text { sexual } \\
\text { intercourse }\end{array}$ & 20 & & $\begin{array}{l}2 \\
5\end{array}$ & 19 & 9 & 17 & $\begin{array}{l}1 \\
6\end{array}$ & 16 & $\begin{array}{l}2 \\
1\end{array}$ & 17 & 6 & 17 & 32 & 19 & $\begin{array}{l}2 \\
2\end{array}$ & 18 & $\begin{array}{l}1 \\
1\end{array}$ \\
\hline $\begin{array}{l}\text { Age at first } \\
\text { pregnancy }\end{array}$ & 21 & & $\begin{array}{l}2 \\
5\end{array}$ & 21 & 9 & 21 & $\begin{array}{l}1 \\
6\end{array}$ & 19 & $\begin{array}{l}2 \\
4\end{array}$ & 20 & 6 & 18 & 32 & 20 & $\begin{array}{l}2 \\
2\end{array}$ & 20 & $\begin{array}{l}1 \\
1\end{array}$ \\
\hline
\end{tabular}

\section{Community midwife responses by district}

\begin{tabular}{|c|c|c|c|c|c|}
\hline Indicator & $\begin{array}{l}\text { Nyandarua } \\
(\mathrm{n}=21) \\
\%\end{array}$ & $\begin{array}{l}\text { Mwingi } \\
(\mathrm{n}=10) \\
\%\end{array}$ & $\begin{array}{l}\text { Kilifi } \\
(n=12) \\
\%\end{array}$ & $\begin{array}{l}\text { Taita } \\
\text { Taveta } \\
(n=13) \\
\%\end{array}$ & $\begin{array}{l}\text { Total } \\
(\mathrm{n}=56) \\
\%\end{array}$ \\
\hline \multicolumn{6}{|l|}{ Diagnosing/predicting obstructed labour: } \\
\hline Woman is very young - teenage & 19 & 10 & 8 & 15 & 14 \\
\hline History of previous operative delivery or $\mathrm{C} / \mathrm{S}$ & 14 & 20 & 0 & 31 & 16 \\
\hline History of stillbirth associated with labour & 5 & 20 & 0 & 23 & 11 \\
\hline History of prolonged labour in previous births & 19 & 20 & 25 & 38 & 25 \\
\hline Maternal distress or exhaustion & 67 & 80 & 50 & 77 & 68 \\
\hline Foetal distress or exhaustion & 57 & 80 & 42 & 85 & 64 \\
\hline Dehydration & 14 & 40 & 25 & 8 & 20 \\
\hline $\begin{array}{l}\text { Foetal head may be palpable above the pelvic } \\
\text { brim although the woman is in advanced labour }\end{array}$ & 52 & 80 & 58 & 77 & 64 \\
\hline $\begin{array}{l}\text { Frequent and very strong contractions with } \\
\text { minimal or no cervical dilatation sometimes titanic } \\
\text { uterine contractions }\end{array}$ & 43 & 90 & 58 & 62 & 59 \\
\hline Presence of a Bandl's ring & 48 & 50 & 33 & 100 & 57 \\
\hline Meconium liquor & 19 & 40 & 8 & 46 & 27 \\
\hline Dry birth canal or vagina & 52 & 30 & 25 & 23 & 36 \\
\hline Oedema of the cervix and sometimes the labia & 5 & 40 & 17 & 46 & 23 \\
\hline Formation of a large caput succedaneum & 5 & 40 & 17 & 38 & 21 \\
\hline Excessive moulding of the foetal head & 10 & 20 & 17 & 62 & 25 \\
\hline Partograph does not progress & 14 & 60 & 17 & 54 & 32 \\
\hline More than 12 hours in labour & 29 & 70 & 42 & 77 & 50 \\
\hline
\end{tabular}




\begin{tabular}{|c|c|c|c|c|c|}
\hline Indicator & $\begin{array}{l}\text { Nyandarua } \\
(n=21) \\
\%\end{array}$ & $\begin{array}{l}\text { Mwingi } \\
(n=10) \\
\%\end{array}$ & $\begin{array}{l}\text { Kilifi } \\
(n=12) \\
\%\end{array}$ & $\begin{array}{l}\text { Taita } \\
\text { Taveta } \\
(n=13) \\
\%\end{array}$ & $\begin{array}{l}\text { Total } \\
(n=56) \\
\%\end{array}$ \\
\hline Full bladder & 0 & 0 & 0 & 8 & 2 \\
\hline High blood pressure & 5 & 0 & 0 & 0 & 2 \\
\hline Elderly primigravida & 0 & 10 & 0 & 0 & 2 \\
\hline Abnormal presentation/malpresentation & 19 & 0 & 0 & 0 & 7 \\
\hline Premature rupture of membranes & 5 & 0 & 0 & 0 & 2 \\
\hline \multicolumn{6}{|c|}{ What to use in diagnosing prolonged/obstructed labour: } \\
\hline Partograph & 95 & 90 & 92 & 100 & 95 \\
\hline ANC card & 33 & 10 & 25 & 23 & 25 \\
\hline Patients notes & 19 & 40 & 17 & 15 & 21 \\
\hline Physical examination & 76 & 100 & 50 & 62 & 71 \\
\hline \multicolumn{6}{|l|}{ Factors are associated with obstructed labour: } \\
\hline Child malnutrition & 10 & 20 & 8 & 23 & 14 \\
\hline Young mothers of less than 18 years & 71 & 70 & 67 & 38 & 63 \\
\hline Female genital cutting & 10 & 30 & 0 & 38 & 18 \\
\hline Poor access to emergency obstetric care & 5 & 90 & 8 & 46 & 30 \\
\hline Inadequate pelvis & 24 & 20 & 17 & 23 & 21 \\
\hline Mal/breach presentation & 62 & 20 & 17 & 15 & 34 \\
\hline High parity & 5 & 10 & 0 & 0 & 4 \\
\hline Prolonged labour & 5 & 0 & 0 & 0 & 2 \\
\hline Previous C/S scar & 5 & 0 & 0 & 0 & 2 \\
\hline Poor maternal health & 5 & 0 & 0 & 0 & 2 \\
\hline \multicolumn{6}{|l|}{ How obstetric fistula presents: } \\
\hline Involuntary leakage/ incontinence of urine & 100 & 100 & 100 & 100 & 100 \\
\hline Involuntary leakage/ incontinence of feacal matter & 86 & 80 & 75 & 69 & 79 \\
\hline Difficulty in walking & 33 & 40 & 0 & 38 & 29 \\
\hline Incontinence of both urine and faeces & 5 & 0 & 0 & 0 & 2 \\
\hline Bleeding/pain if fresh & 19 & 10 & 0 & 0 & 9 \\
\hline Urinary tract infection & 5 & 0 & 0 & 8 & 4 \\
\hline Signs of distress & 5 & 0 & 0 & 0 & 2 \\
\hline Foul smell & 5 & 30 & 25 & 8 & 14 \\
\hline \multicolumn{6}{|l|}{ Action for obstructed labour: } \\
\hline Advise family they need to take her to hospital & 57 & 90 & 42 & 69 & 63 \\
\hline Advise family to organise transport to hospital & 33 & 50 & 50 & 46 & 43 \\
\hline Put up IV dextrose & 57 & 50 & 83 & 15 & 52 \\
\hline Call ambulance & 43 & 40 & 58 & 54 & 48 \\
\hline $\begin{array}{l}\text { Call facility to be prepared to accept women for } \\
\text { C/S }\end{array}$ & 48 & 60 & 42 & 54 & 50 \\
\hline Accompany mother for referral & 19 & 10 & 8 & 15 & 14 \\
\hline Explain to client/family about her condition & 19 & 20 & 8 & 0 & 13 \\
\hline Write a referral letter & 10 & 0 & 8 & 8 & 7 \\
\hline Examine mother & 5 & 0 & 8 & 8 & 5 \\
\hline Insert catheter & 0 & 0 & 0 & 8 & 2 \\
\hline \multicolumn{6}{|c|}{ Relationship with groups and organizations in the area of operation: } \\
\hline $\begin{array}{l}\text { Have established a working relationship with } \\
\text { groups/organizations in there are of operation }\end{array}$ & 100 & 100 & 92 & 85 & 94 \\
\hline Chief and sub chiefs/provincial administration & 76 & 100 & 75 & 46 & 73 \\
\hline Village Councils & 38 & 50 & 42 & 23 & 38 \\
\hline Women's groups & 95 & 60 & 50 & 54 & 70 \\
\hline
\end{tabular}




\begin{tabular}{|c|c|c|c|c|c|}
\hline Indicator & $\begin{array}{l}\text { Nyandarua } \\
(\mathrm{n}=21) \\
\%\end{array}$ & $\begin{array}{l}\text { Mwingi } \\
(n=10) \\
\%\end{array}$ & $\begin{array}{l}\text { Kilifi } \\
(n=12) \\
\%\end{array}$ & $\begin{array}{l}\text { Taita } \\
\text { Taveta } \\
(n=13) \\
\%\end{array}$ & $\begin{array}{l}\text { Total } \\
(n=56) \\
\%\end{array}$ \\
\hline Youth groups & 33 & 20 & 8 & 15 & 21 \\
\hline Religious leaders & 86 & 50 & 25 & 31 & 54 \\
\hline Farmers union & 5 & 10 & 0 & 15 & 7 \\
\hline $\mathrm{CHWs}$ & 67 & 50 & 25 & 8 & 41 \\
\hline TBAs & 19 & 30 & 58 & 31 & 32 \\
\hline NGOs \& CBO working in the community & 5 & 20 & 8 & 23 & 13 \\
\hline Credit facilities & 10 & 0 & 8 & 0 & 5 \\
\hline Health facilities & 0 & 0 & 17 & 0 & 4 \\
\hline \multicolumn{6}{|l|}{ Attached to a health facility for support: } \\
\hline Are attached to a health facility for support & 95 & 100 & 100 & 100 & 98 \\
\hline Dispensary & 29 & 0 & 33 & 31 & 25 \\
\hline Health Centre & 33 & 40 & 17 & 8 & 25 \\
\hline Sub District Hospital & 10 & 30 & 0 & 0 & 9 \\
\hline District Hospital & 33 & 40 & 42 & 77 & 46 \\
\hline PGH & 0 & 0 & 8 & 0 & 2 \\
\hline Private health facilities & 0 & 0 & 33 & 8 & 9 \\
\hline \multicolumn{6}{|l|}{ Distance from health facility: } \\
\hline Less than $1 \mathrm{~km}$ & 19 & 20 & 8 & 8 & 14 \\
\hline $1-5 \mathrm{kms}$ & 67 & 30 & 75 & 61 & 60 \\
\hline $6-10 \mathrm{kms}$ & 14 & 10 & 17 & 15 & 14 \\
\hline $11-15 \mathrm{kms}$ & 0 & 20 & 0 & 0 & 4 \\
\hline $16-20 \mathrm{kms}$ & 0 & 10 & 0 & 8 & 4 \\
\hline $21-25 \mathrm{kms}$ & 0 & 10 & 0 & 8 & 4 \\
\hline \multicolumn{6}{|c|}{ Means of transport to health facility of attachment: } \\
\hline Walk & 67 & 70 & 42 & 69 & 63 \\
\hline Bicycle & 5 & 10 & 0 & 38 & 13 \\
\hline Cart & 0 & 0 & 17 & 0 & 4 \\
\hline Motorbike & 10 & 10 & 17 & 31 & 16 \\
\hline Matatu & 33 & 40 & 50 & 31 & 38 \\
\hline Private car & 19 & 0 & 25 & 15 & 16 \\
\hline Ambulance & 0 & 10 & 8 & 23 & 9 \\
\hline Public vehicle & 0 & 0 & 0 & 0 & 0 \\
\hline Taxi/tuk-tuk & 0 & 0 & 17 & 0 & 4 \\
\hline \multirow[t]{2}{*}{ Bus } & 5 & 0 & 0 & 0 & 2 \\
\hline & $(\mathbf{n = 2 1 )}$ & $(n=10)$ & $(n=11)$ & $(n=13)$ & $(n=55)$ \\
\hline \multicolumn{6}{|c|}{ Means of transport to health facility for clients during emergency: } \\
\hline None & 5 & 0 & 9 & 31 & 11 \\
\hline Bicycle & 5 & 0 & 0 & 8 & 4 \\
\hline Cart & 5 & 0 & 0 & 0 & 2 \\
\hline Bicycle trailer/ambulance & 19 & 10 & 18 & 8 & 15 \\
\hline Matatu & 43 & 90 & 18 & 8 & 38 \\
\hline Private car & 33 & 20 & 36 & 31 & 31 \\
\hline Ambulance & 57 & 30 & 45 & 31 & 44 \\
\hline
\end{tabular}




\begin{tabular}{|c|c|c|c|}
\hline & Authors & Title and Publication & Comments \\
\hline A) & \multicolumn{3}{|c|}{ Clinical/management in Kenya/East Africa } \\
\hline & Kenya Ministry of Health & $\begin{array}{l}\text { Kenya National Obstetric Fistulae } \\
\text { Training Curriculum for Health Care } \\
\text { Workers. 2006. MOH, UNFPA, } \\
\text { EngenderHealth, Satat, Moi } \\
\text { University, et al }\end{array}$ & $\begin{array}{l}\text { The curriculum was developed for use to train service providers using a multi-disciplinary approach } \\
\text { for effective management of obstetric fistula. There are few gynecologists who have expertise in } \\
\text { obstetric fistula treatment and care in the country and patients treated are not effectively } \\
\text { rehabilitated. The training entails training core teams, which include doctors, nurses, anesthetists, } \\
\text { physiotherapists, and social workers. }\end{array}$ \\
\hline & Mahendeka M. & $\begin{array}{l}\text { The management of vesico and/or } \\
\text { recto-vaginal fistulae at Bugando } \\
\text { Medical Centre, Mwanza, Tanzania, } \\
\text { East Africa: a retrospective study. } \\
\text { Obstetrician and Gynecologist, } \\
\text { Bugando Medical Centre; } \\
\text { P.O. Box 1370, Mwanza, Tanzania, } \\
\text { East Africa } \\
\text { E-mail: } \\
\text { hospital@bugandomedicalcentre.go. } \\
\text { tz }\end{array}$ & $\begin{array}{l}\text { A modified management of the vesico and/or recto-vaginal fistulae compared to a usual } \\
\text { management has been studied at Bugando Medical Centre, Mwanza, Tanzania, East Africa. In the } \\
\text { modified method, out of } 100 \text { patients with a vesico and/or recto-vaginal fistula of } 21 \text { days - } 37 \\
\text { years duration, } 92 \text { ( } 92 \% \text { ) were closed after the first operative attempt at a total cost of } 45-70 \text { USD } \\
\text { per patient and a hospital stay of up to } 30 \text { days. Whilst in the group using the usual method, out of } \\
100 \text { patients with a vesico and/or recto-vaginal fistula of } 97 \text { days - } 37 \text { years, } 90 \text { ( } 90 \% \text { ) were closed } \\
\text { after the first operative attempt at a total cost of } 60-300 \text { USD per patient and a hospital stay of up } \\
\text { to } 10 \text { months. The modified management, in addition to the equal rate of closure and lesser cost } \\
\text { has other important advantages: it prevents the woman from becoming an outcast, reduces } \\
\text { hospital stay, and offers less operative procedures to the patient. }\end{array}$ \\
\hline & $\begin{array}{l}\text { Raassen, Tom, Emiel, } \\
\text { J.I.P, Verdaasdonk, G.G., } \\
\text { Vierhout E., Mark }\end{array}$ & $\begin{array}{l}\text { Prospective results after first time } \\
\text { surgery for obstetric fistulas in East } \\
\text { African women. } \\
\text { International Urogynecology Journal } \\
2007: 19: 73-79\end{array}$ & $\begin{array}{l}\text { Data were collected prospectively from patients operated on between January } 2001 \text { and August } \\
2003 \text {. Only patients who received surgery for the first time and whose fistula was caused by } \\
\text { obstructed labour were included. Study included } 581 \text { women (91\%) out of } 647 \text { patients who } \\
\text { underwent fistula treatment and care. } 45 \% \text { of the women were primigravida and perinatal survival } \\
11.5 \% .41 \% \text { lived apart from their partner. Women operated on within three months had slightly } \\
\text { better surgical outcome } 94 \% \text { vs. } 87 \% \text {. }\end{array}$ \\
\hline & Mabeya, Hillary M. & $\begin{array}{l}\text { Characteristics of women admitted } \\
\text { with obstetric fistula in the rural } \\
\text { hospitals in West Pokot, Kenya }\end{array}$ & $\begin{array}{l}\text { A 5-year study from Jan } 1999 \text { to Dec } 2003 ; 66 \text { patients were analyzed. The prevalence of obstetric } \\
\text { fistula was } 1 \text { per } 1000 \text { women. } 65 \% \text { had onset of fistula at } 20 \text { years of age and less; } 55 \% \text { were } \\
\text { primigravida; } 59 \% \text { had no formal education. } 87 \% \text { success rate at first treatment and care attempt; } \\
80 \% \text { had undergone severe FGM, } 68 \% \text { of the deliveries were stillbirths and } 73 \% \text { of women had } \\
\text { prolonged labor. } \\
\text { Conclusion: prolonged labor, age, severe FGM, level of education, parity, occupation, lack of } \\
\text { transport and primary health care community and early marriage were characterized the fistula }\end{array}$ \\
\hline
\end{tabular}




\begin{tabular}{|c|c|c|}
\hline Authors & Title and Publication & Comments \\
\hline & & $\begin{array}{l}\text { patients. Successful treatment and care was high at first attempt with trained staff and good } \\
\text { hospital facilities. }\end{array}$ \\
\hline \multicolumn{3}{|c|}{ Clinical/management in countries south of the Sahara } \\
\hline & $\begin{array}{l}\text { Vesico-uterine fistula following } \\
\text { caesarian delivery. } \\
\text { Ultrasound Obstetgyncol 2005; 26: } \\
\text { 183-185 Published by John Wiley } \\
\text { and sons, Ltd. }\end{array}$ & $\begin{array}{l}\text { Vesico-uterine fistulae are uncommon, with most units reporting } 1-5 \text { cases over } 5-15 \text { year } \\
\text { periods. To date there has been a paucity of case reports regarding this problem and only a few } \\
\text { case series. The report outlines the presentation and management of a vesico-uterine fistula } \\
\text { complicating a repeat cesarean delivery, specifically describing the role of trans-vaginal ultrasound. }\end{array}$ \\
\hline $\begin{array}{l}\text { Ahmed, S., } \\
\text { Holtz, S.A. }\end{array}$ & $\begin{array}{l}\text { Social and Economic consequences } \\
\text { of obstetric fistula: life changed } \\
\text { forever? } \\
\text { International Journal of Gynecology } \\
\text { and Obstetrics (2007) } 99 \text { S10-S15 }\end{array}$ & $\begin{array}{l}\text { Summarizes the social, economic, emotional, and psychological consequences incurred by women } \\
\text { with obstetric fistula; presents the results of two major consequences, divorce/separation and } \\
\text { perinatal loss; and reports on the improvements in health and self-esteem and on the possibility of } \\
\text { social reintegration following successful fistula treatment and care. Recommends that with } \\
\text { additional social support and counseling, women may be able to successful reintegrate socially } \\
\text { following fistula treatment and care. }\end{array}$ \\
\hline Arrowsmith, S.D. & $\begin{array}{l}\text { The classification of obstetric vesico- } \\
\text { vaginal fistulas a call for an } \\
\text { evidence-based approach. } \\
\text { International Journal of Gynecology } \\
\text { and Obstetrics (2007) 99, S25 - S27 }\end{array}$ & $\begin{array}{l}\text { Nearly all VVF classification systems have been based on descriptions of the size and anatomic } \\
\text { location of the defect. While useful in communicating the appearance of a given fistula, systems } \\
\text { based on size and anatomy do not necessarily give information on the difficulty of treatment and } \\
\text { care or the prognosis for successful outcome. } \\
\text { Recommendations: a call for classification system for VVFs based on outcome rather than } \\
\text { anatomy, developing a reliable system will require data resources that do not yet exist. Based on } \\
\text { incomplete data from a Nigerian VVF center, a possible system is proposed for further study. Once } \\
\text { available, an outcome- based classification system could be vital in selecting fistula cases } \\
\text { appropriate for training surgeons, and improving communication with patients. }\end{array}$ \\
\hline Browning, A. & $\begin{array}{l}\text { Obstetric fistula: clinical } \\
\text { considerations in the creation of a } \\
\text { new urethra and the management of } \\
\text { a subsequent pregnancy. } \\
\text { International Journal of Gynecology } \\
\text { and Obstetrics (2007) 99, S94-S97 } \\
\text { International Federation of } \\
\text { Gynecology and Obstetrics. } \\
\text { Published: Elsevier Ireland Ltd. }\end{array}$ & $\begin{array}{l}\text { The paper presents two case studies to illustrate the complexity of treatment and care for obstetric } \\
\text { fistula (OF) with neourethral construction when complete circumferential destruction occurred. } \\
\text { The author describes the personal story and contexts leading to OF development and depression, } \\
\text { surgical options, and the prognosis of treatment and care. These cases were documented at the } \\
\text { Barhirdar Hamlin Fistula Center in Northern Ethiopia. }\end{array}$ \\
\hline
\end{tabular}




\begin{tabular}{|c|c|c|}
\hline Authors & Title and Publication & Comments \\
\hline $\begin{array}{l}\text { Chilopora, G.C., } \\
\text { Rijken, Y. }\end{array}$ & $\begin{array}{l}\text { Urogenital and recto-vaginal fistulas } \\
\text { in Southern Malawi: A report on } 407 \\
\text { patients. } \\
\text { International Journal Of Gynecology } \\
\text { And Obstetrics (2007) 99, S85 - S89 }\end{array}$ & $\begin{array}{l}\text { This study from reports on } 407 \text { patients with } 408 \text { vaginal fistulas ( } 1 \text { patient had } 2 \text { successive } \\
\text { fistulas). There were } 29 \text { patients ( } 7.6 \% \text { ) with a combined urogenital and recto-vaginal fistula. } \\
\text { Obstructed labour was the cause of } 379 \text { fistulas; the incidence is probably much lower in Malawi } \\
\text { than in other African countries. The rate of closure at first repair was } 94.1 \% \text { for urogenital fistulas } \\
\text { but reached } 98.5 \% \text { overall. For recto-vaginal fistulas, closure at first repair was } 79 \% \text { but the overall } \\
\text { rate of successful closure was } 88 \% \text {, stress incontinence was seen in } 16 \% \text { of the clients immediately } \\
\text { after repair and in } 6 \% \text { after } 6 \text { months. A national fistula task force has been set up in Malawi. }\end{array}$ \\
\hline $\begin{array}{l}\text { Creanga, A.A., } \\
\text { Genadry, R.R., } \\
\text { Roenneburg, M.L., } \\
\text { Wheelees, C.R. }\end{array}$ & $\begin{array}{l}\text { Complex obstetric fistulas } \\
\text { International Journal of Gynecology } \\
\text { (2007) 99, S51-556 } \\
\text { International Federation of } \\
\text { Gynecology and Obstetrics. } \\
\text { Published by Elsevier Ireland Ltd. }\end{array}$ & $\begin{array}{l}\text { Obstetric fistulas are rarely simple. Most patients in sub-Saharan Africa and parts of Asia are } \\
\text { carriers of complex fistulas or complicated fistulas requiring expert skills for evaluation and } \\
\text { management. A fistula is predictably complex when it is greater than } 4 \mathrm{~cm} \text { and involves the } \\
\text { continence mechanism (the urethra is partially absent, the bladder capacity is reduced, or both) is } \\
\text { associated with moderately severe scarring of the trigone and urethrovesical junction and/or has } \\
\text { multiple openings. A fistula is even more complicated when it is more than } 6 \mathrm{~cm} \text { in its largest } \\
\text { dimension, particularly when it is associated with severe scarring and the absence of the urethra } \\
\text { and/or when it's combined with a recto-vaginal fistula. The present article reviews the evaluation } \\
\text { methods and main surgical techniques used in the management of complex fistulas. The severity of } \\
\text { the neurovascular alterations associated with these lesion, as well as inescapable limitations in } \\
\text { staff, health facilities and supplies make their optimal management very challenging. }\end{array}$ \\
\hline $\begin{array}{l}\text { Creanga, A.A., Genadry, } \\
\text { R.R }\end{array}$ & $\begin{array}{l}\text { Obstetric fistulas: A clinical review } \\
\text { International Journal of Gynecology } \\
\text { and Obstetrics (2007) 99, S40-S46 }\end{array}$ & $\begin{array}{l}\text { The literature reports } 3 \text { approaches to fistula repair: vaginal, abdominal and combined vaginal and } \\
\text { abdominal. Many authors report high success rates for the surgical closure of obstetric fistulas at } \\
\text { the time of hospital discharge, without further evaluation of the repairs effect on urinary } \\
\text { continence or subsequent quality of life. Data on obstetric fistulas are scarce and thus many } \\
\text { questions regarding fistula management remain unanswered. A standardized terminology and } \\
\text { classification, as well as a data reporting system on the surgical management of obstetric fistulas } \\
\text { and its outcomes are critical steps that need to be taken immediately. }\end{array}$ \\
\hline $\begin{array}{l}\text { Dodson, J.L., } \\
\text { Gutman, R.E., Mostwin, } \\
\text { J.L. }\end{array}$ & $\begin{array}{l}\text { Complications of treatment of } \\
\text { obstetric fistula in the developing } \\
\text { world: gynatresia, urinary } \\
\text { incontinence, and urinary diversion } \\
\\
\text { International Journal Of Gynecology } \\
\text { and Obstetrics (2007) } 99, \text { S75 - S78 } \\
\text { International Federation of } \\
\text { Gynecology and Obstetrics. } \\
\text { Published by Elsevier Ireland Ltd. }\end{array}$ & $\begin{array}{l}\text { Objective: to provide a comprehensive review of the pathophysiology, evaluation, and treatment } \\
\text { of gynatresia and urinary incontinence, two conditions that can arise following the repair of } \\
\text { obstetric fistulas. The article discusses relevant issues with respect to urinary diversion in the } \\
\text { treatment of obstetrical fistula and associated urinary incontinence. Results: Gynatresia and } \\
\text { urinary incontinence develop in approximately } 10 \% \text { and } 16 \% \text { of patients, respectively, after the first } \\
\text { repair. Urinary diversion may be necessary when fistulas cannot be closed vaginally or in cases of } \\
\text { severe urinary diversion are all associated with morbidity. And they require surgical and non- } \\
\text { surgical expertise from proper management. Conclusions: closing the prevention and repair of } \\
\text { gynatresia and urinary incontinence at the time of the primary operation. }\end{array}$ \\
\hline
\end{tabular}




\begin{tabular}{|c|c|c|}
\hline Authors & Title and Publication & Comments \\
\hline Hilton, $\mathrm{P}$. & $\begin{array}{l}\text { Vesico-Vaginal fistulas in Developing } \\
\text { Countries. } \\
\text { International Journal of Gynecology } \\
\text { and Obstetrics (2006) 82, p285-295. }\end{array}$ & $\begin{array}{l}\text { VVF remains a major public health issue in the developing world. Over } 80 \% \text { of cases result from } \\
\text { neglected obstructed labour, and the condition may follow } 1-2 \text { per } 1000 \text { deliveries, with an annual } \\
\text { worldwide incidence of up to } 500000 \text { cases. The principles of investigation and treatment are } \\
\text { reviewed in this paper, although national and international strategies aimed at prevention are } \\
\text { much more important to the ultimate eradication of this devastating condition. Such strategies } \\
\text { much include government recognition of fistulae as a major public health concern, improvement in } \\
\text { the status of women in society, the extension of primary education particularly for girls, and } \\
\text { affordable, accessible and acceptable services for all pregnant women. }\end{array}$ \\
\hline $\begin{array}{l}\text { Kelly, J., } \\
\text { Winter, H.R. }\end{array}$ & $\begin{array}{l}\text { Reflection on the knowledge base } \\
\text { for obstetric fistula. } \\
\text { International Journal of Gynecology } \\
\text { and Obstetrics (2007) 99, S21 - S24 } \\
\text { International Federation of } \\
\text { Gynecology and Obstetrics. } \\
\text { Published by Elsevier Ireland Ltd. }\end{array}$ & $\begin{array}{l}\text { Presents the reflections of an experienced fistula surgeon and an epidemiologist on the current } \\
\text { knowledge base for obstetric fistula. The incidence, prevention, and management of vesico - } \\
\text { vaginal and recto - vaginal fistula are discussed. The authors call for more randomized controlled } \\
\text { trials to determine the effectiveness of surgical interventions for fistula repair. }\end{array}$ \\
\hline Lassey, A.T. & $\begin{array}{l}\text { Simple fistulas: Diagnosis and } \\
\text { management in low-resource } \\
\text { settings- A descriptive report. } \\
\text { International Journal of Gynecology } \\
\text { and Obstetrics (2007) } 99,547-550 \\
\text { International Federation of } \\
\text { Gynecology and Obstetrics. } \\
\text { Published by Elsevier Ireland Ltd. }\end{array}$ & $\begin{array}{l}\text { OF occurs in developing countries because of the lack of obstetric services. Describes a basic } \\
\text { approach to the care of women with fistulas in a low-resource rural hospital in northern Ghana, } \\
\text { where the results were similar to those obtained at better-equipped centers. The facility includes } \\
\text { an out-patient clinic for history taking and clinical examinations and a lab for hemoglobin } \\
\text { concentration assessment, sickling test, blood grouping and cross-matching when necessary. } \\
\text { Anesthesia consists of a spinal anesthesia given by the surgeon and monitored by a nurse while the } \\
\text { surgeon scrubs up before repairing the fistula. Surgery is performed with the patient in } \\
\text { exaggerated lithotomy position and bed sheet used as a sling prevents her from falling backwards. } \\
\text { The patients are kept in hospital for } 14 \text { days postoperatively for continuous bladder drainage. }\end{array}$ \\
\hline $\begin{array}{l}\text { Ojengbede, O.A., } \\
\text { Morhason-Bello, I.O. }\end{array}$ & $\begin{array}{l}\text { Local anesthesia: an appropriate } \\
\text { technology for simple fistula repair. } \\
\text { International Journal of Gynecology } \\
\text { and Obstetrics (2007) } 99, \text { S75 - S78 } \\
\text { International Federation of } \\
\text { Gynecology and Obstetrics. } \\
\text { Published by Elsevier Ireland Ltd. }\end{array}$ & $\begin{array}{l}\text { Objectives: to assess the efficacy of local infiltrative anesthesia with lidocaine hydrochloride in } \\
\text { patients undergoing the surgical repair of a simple vesico - vaginal fistula. Methods: the study was } \\
\text { carried out with } 21 \text { patients undergoing the repair of a simple mid-vaginal vesico - vaginal fistula. } \\
\text { The patients' perception of pain was evaluated intra-operatively. Result: most patients indicated } \\
\text { that the anesthetic agent provides adequate analgesia, and all fistulas were repaired successfully } \\
\text { without postoperative complications. Conclusion: repairing simple vesico - vaginal fistulas is } \\
\text { feasible with a local infiltrative anesthetic. }\end{array}$ \\
\hline
\end{tabular}




\begin{tabular}{|c|c|c|}
\hline Authors & Title and Publication & Comments \\
\hline \multicolumn{3}{|c|}{ B Influencing policy - Kenya/East Africa } \\
\hline Bangser, M. & $\begin{array}{l}\text { Tanzania Fistula Survey, } 2002 . \\
\text { UNFPA, Ministry of Health and } \\
\text { Woman's Dignity Project }\end{array}$ & $\begin{array}{l}\text { The purpose of the survey was to disseminate information widely to health workers and } \\
\text { communities on where services are available; Identify major gaps in fistula services throughout the } \\
\text { country; and establish a national referral system for fistula care. Major findings were: the largest } \\
\text { concentration of hospitals providing fistula repairs is around the perimeter of Tanzania; fistula care } \\
\text { is largely unavailable and inaccessible in Singida, Dodoma, Tabora and Rukwa where there few } \\
\text { specialists in gynaecology and surgery; many women seeking fistula repairs have to travel more } \\
\text { than 500km to access services; a large number of repair centers rely on foreign visiting surgeons; } \\
\text { the cost of repair and transport is an impediment to many in accessing obstetric fistula repair. }\end{array}$ \\
\hline Bangser, M. & $\begin{array}{l}\text { Strengthening public health priority } \\
\text { setting through research on fistula, } \\
\text { maternal health and health } \\
\text { inequities. } \\
\text { International Journal of Gynecology } \\
\text { and Obstetrics (2007) 99, S16-S20 }\end{array}$ & $\begin{array}{l}\text { Findings from four studies by the Women's Dignity project and partners on obstetric fistula, } \\
\text { maternal mortality and morbidity, and health inequities in Tanzania. } \\
\text { Provides policy makers, program managers and service providers with evidence and the impetus to } \\
\text { re-equilibrate policies, financial and human resources, and services in the interest of those in the } \\
\text { greatest need, i.e. women living in poverty. }\end{array}$ \\
\hline $\begin{array}{l}\text { Bangser, M., } \\
\text { Mehta, M. }\end{array}$ & $\begin{array}{l}\text { Risk and Resilience: Obstetric Fistula } \\
\text { in Tanzania } \\
\text { Women's Dignity Project and } \\
\text { Engender Health in partnership with } \\
\text { Health Action Promotion } \\
\text { Association, Kivulini Woman's Rights } \\
\text { Organization and Peramiho Mission } \\
\text { Hospital, November } 2006 \text {. }\end{array}$ & $\begin{array}{l}\text { A study to understand the many dimensions of fistula and its related social vulnerability through } \\
\text { the experiences and views of girls and women living with fistula as well as their families and } \\
\text { communities and the health workers who care for them. The study also explored locally } \\
\text { appropriate solutions to prevent and manage fistula. Key findings: fistula affects girls and women } \\
\text { of all ages, both in first pregnancy and in later pregnancies; ANC while widely available and used } \\
\text { are inconsistent and inadequate; the lack of birth preparedness, including basic information on } \\
\text { child birth and taking action around delays, increases risk; lack of access to emergency caesarian } \\
\text { section poses a great threat to women's lives; the cost and inaccessibility of high quality fistula } \\
\text { repair services represent a barrier to care for many girls and women; even though women with } \\
\text { fistula have support from others, the emotional and economic impacts of fistula are substantial for } \\
\text { the woman herself, as well as her family. }\end{array}$ \\
\hline
\end{tabular}




\begin{tabular}{|c|c|c|}
\hline Authors & Title and Publication & Comments \\
\hline $\begin{array}{l}\text { Chong, E., } \\
\text { Thoraya, A.O. }\end{array}$ & $\begin{array}{l}\text { Healing the wounds, instilling hope: } \\
\text { The Tanzanian Partnership Against } \\
\text { Obstetric Fistula. } 2004 . \\
\text { UNFPA, Robert H. Ebert Program, } \\
\text { Population Council; the Ford } \\
\text { Foundation; and the Development } \\
\text { Program of the Population Council. }\end{array}$ & $\begin{array}{l}\text { Highlights the definition, causes and the National efforts to eliminate obstetric fistula with case } \\
\text { study of women treated at Bugando Medical Center. } \\
\text { Recommendations: A multidimensional approach is required to combat fistula effectively; majority } \\
\text { of fistula cases can be successfully repaired or dramatically improved if the repair performed is of } \\
\text { high quality, the positive difference a successful repair makes in a woman's life is enormous; policy } \\
\text { makers, surgeons, and donors who have viewed fistula as overwhelming and immutable problem } \\
\text { are often inspired by individual stories to tackle the issue and to commit their resources to the } \\
\text { task; fistula repair is a good economic investment; the wide spread incidence of fistula reflects the } \\
\text { problems poor women face generally, efforts to reduce the incidence of the condition can serve to } \\
\text { build awareness of women's right to health care and of gender issues of power. }\end{array}$ \\
\hline $\begin{array}{l}\text { Kenya Ministry of } \\
\text { Health, Division of } \\
\text { Reproductive Health and } \\
\text { UNFPA }\end{array}$ & $\begin{array}{l}\text { Needs Assessment of Obstetric } \\
\text { Fistula in Kenya. 2004. UNFPA, State } \\
\text { of World Population 2004. }\end{array}$ & $\begin{array}{l}\text { The exercise sought to establish the magnitude of obstetric fistula, and contextual factors related } \\
\text { to obstetric fistula such as community understanding of the problem in terms of causes, prevention } \\
\text { and treatment, availability of services, care seeking behaviour and constraints. The study was } \\
\text { conducted in Kwale, Mwingi, West Pokot and Homabay Districts. } \\
\text { Recommendations: the need for training in fistula surgery, subsidy of fistula surgery in provincial } \\
\text { and district hospitals and prevention of the occurrence of obstetric fistula in the community by } \\
\text { extending midwifery skills to the community. }\end{array}$ \\
\hline Woman's Dignity Project & $\begin{array}{l}\text { In their own words: Poor women } \\
\text { and health services. } \\
\text { Woman's Dignity Project /Utu } \\
\text { Mwanamke, Dar es salaam Tanzania }\end{array}$ & $\begin{array}{l}\text { Highlights critical constraints that poor women experience in accessing health services, including } \\
\text { the challenges they face and the strategies they use to overcome them. This summary report is } \\
\text { meant to inform policy development and resource allocation in relation to basic services for the } \\
\text { poor, and to mobilize the financial, human and material resources necessary to strengthen health } \\
\text { services for women living in poverty. Four main issues raised by the women participating in the } \\
\text { study point to key considerations for improving health services for the poor: access to health } \\
\text { services; cost and affordability of services; governance; and accountability. }\end{array}$ \\
\hline \multicolumn{3}{|c|}{ Global policy and recommendations } \\
\hline $\begin{array}{l}\text { Ahmed, S., } \\
\text { Creanga, A.A., } \\
\text { Tsui, A.O. }\end{array}$ & $\begin{array}{l}\text { The role of delayed child bearing in } \\
\text { the prevention of obstetric fistulas. } \\
\text { International Journal of Gynecology } \\
\text { and Obstetrics (2007) 99, S98-S107 }\end{array}$ & $\begin{array}{l}\text { Examines the role of delayed childbearing in the prevention obstetric fistulas. } \\
\text { Recommends that community programs to educate young, newly married women about delaying } \\
\text { childbearing until they reach physical maturity be implemented in countries with a high incidence } \\
\text { of obstetric fistulas. }\end{array}$ \\
\hline
\end{tabular}




\begin{tabular}{|c|c|c|}
\hline Authors & Title and Publication & Comments \\
\hline $\begin{array}{l}\text { Ahmed, S., } \\
\text { Holtz, S.A, } \\
\text { Stanton, C. }\end{array}$ & $\begin{array}{l}\text { Challenges in measuring obstetric } \\
\text { fistula. } \\
\text { International Journal of Gynecology } \\
\text { and Obstetrics (2007) } 99 \text { S4-S9 }\end{array}$ & $\begin{array}{l}\text { An assessment of the state of knowledge regarding population-based estimates of the incidence } \\
\text { and prevalence of obstetric fistula; proposes a method for estimating these rates; and discusses } \\
\text { the feasibility of the method. } \\
\text { There are no solid population-based estimates of the number of obstetric fistulas anywhere. To } \\
\text { estimate the incidence and prevalence of obstetric fistulas, it proposes an adaptation of the sibling- } \\
\text { based method for direct estimation of maternal mortality. A series of questions are proposed for } \\
\text { this use. }\end{array}$ \\
\hline $\begin{array}{l}\text { Ahmed, S., } \\
\text { Genadry, R., } \\
\text { Lalonde, A.B., } \\
\text { Stanton, C. }\end{array}$ & $\begin{array}{l}\text { Dead women walking: neglected } \\
\text { millions with Obstetric fistula. } \\
\text { International Journal of Gynecology } \\
\text { and Obstetrics (2007) 99, S1 - S3 }\end{array}$ & $\begin{array}{l}\text { Fistula is considered the most debilitating and devastating of maternal morbidities. When the } \\
\text { woman survives the obstructed labor and is left with an obstetric fistula, she experiences constant } \\
\text { leakage of urine and/or faeces. Once her fistula is established, her life is changed forever, as she is } \\
\text { no longer able to fulfill her societal roles of wife and mother. She is often deserted by her husband } \\
\text { and stigmatized by society. Fistula is preventable and treatable, but still millions of women in } \\
\text { developing countries suffer from this dreadful condition. It was virtually eliminated in the } \\
\text { developed countries by improved and universally accessible obstetric care. It is estimated that the } \\
\text { unmet need for surgical treatment of obstetric fistula could be as high as } 99 \% \text {. }\end{array}$ \\
\hline De Bernis, L. & $\begin{array}{l}\text { Obstetric Fistula: Guiding Principles } \\
\text { for Clinical Management and } \\
\text { Programme Development, A New } \\
\text { WHO Guideline. } \\
\text { Making Pregnancy Safer } \\
\text { Department, WHO Seconded to } \\
\text { UNFPA, Geneva, Switzerland. }\end{array}$ & $\begin{array}{l}\text { A practical working document. Its three main objectives are to draw attention to the urgency of the } \\
\text { OF issue and serve as an advocacy document for prompt action; provide policy makers and health } \\
\text { professionals with brief, factual information and principles that will guide them at the national and } \\
\text { regional revels as they develop strategies and programs to prevent and treat OFs; and assist health } \\
\text { professionals as they acquire better skills and develop more effective services to care for women } \\
\text { treated for fistula repair. }\end{array}$ \\
\hline $\begin{array}{l}\text { Dolea, C., } \\
\text { Abou-Zahr, C. }\end{array}$ & $\begin{array}{l}\text { Global burden of obstructed labour. } \\
\text { Evidence and Information for Policy } \\
\text { WHO Geneva } 2003\end{array}$ & $\begin{array}{l}\text { A literature review of incidence and prevalence sequalae for obstructed labour. } \\
\text { For GBD } 2000 \text { we expressed the obstetric fistula rate of } 0.08 \% \text { of births as a proportion of } \\
\text { neglected obstructed labour cases for the AFRO region. The same rate of } 0.08 \% \text { was used in } \\
\text { GBD1990. This results in an incidence rate of obstetric fistula of } 2.15 \% \text { of neglected obstructed } \\
\text { labour cases. This rate was applied to the regional rates of the neglected obstructed labour to } \\
\text { determine the overall incidence of obstetric fistula. }\end{array}$ \\
\hline $\begin{array}{l}\text { Donnay, F., } \\
\text { Ramsey, K. }\end{array}$ & $\begin{array}{l}\text { Eliminating obstetric fistula: progress } \\
\text { in partnerships. } \\
\text { International Journal of Gynecology } \\
\text { and Obstetrics (2006) 94, 254-261 }\end{array}$ & $\begin{array}{l}\text { Describes the strategies and progress of the global campaign to end fistula: the global campaign } \\
\text { brings a variety of actors together to raise awareness and support to prevent fistula and provide } \\
\text { comprehensive treatment for women living with fistula. }\end{array}$ \\
\hline $\begin{array}{l}\text { Idoko, L., } \\
\text { Iliyasu, Z., }\end{array}$ & $\begin{array}{l}\text { Fistula fortnight: Innovative } \\
\text { partnership brings mass treatment }\end{array}$ & $\begin{array}{l}\text { Part of the global campaign to end fistula. Two weeks mass obstetric fistula treatment project that } \\
\text { was organized in Northern Nigeria to reduce the backlog of untreated fistulas and raise awareness }\end{array}$ \\
\hline
\end{tabular}




\begin{tabular}{|c|c|c|}
\hline Authors & Title and Publication & Comments \\
\hline Ramsey, K. & $\begin{array}{l}\text { and public awareness towards } \\
\text { ending obstetric fistula. } \\
\text { International Journal of Gynecology } \\
\text { and Obstetrics (2007) 94, S130-S142 }\end{array}$ & $\begin{array}{l}\text { regarding obstetric fistulas and safe motherhood between } 21 \text { February and } 6 \text { March } 2005 \text { treating } \\
569 \text { women with } 87.8 \% \text { successful closures. }\end{array}$ \\
\hline Hinrichsen, D. & $\begin{array}{l}\text { Obstetric fistula ending the silence, } \\
\text { easing the suffering. } \\
\text { John Hopkins Bloomberg School of } \\
\text { Public Health Center for } \\
\text { Communication Programs, } 111 \\
\text { Market Place, Suite 310, Baltimore, } \\
\text { MD 21202; www. Inforhealth.org }\end{array}$ & $\begin{array}{l}\text { Obstetric fistula- a devastating medical condition consisting of an abnormal opening between the } \\
\text { vagina and the bladder or rectum - results from unrelieved obstructed labor. Unless the fetus is } \\
\text { delivered surgically, prolonged obstructed labor often ends only when the fetus dies, decomposes, } \\
\text { and finally passed from the mother. In many cases the mother's injured pelvic tissue breaks down, } \\
\text { leaving a hole, or fistula, between adjacent organs. Fistulas also can have non-obstetric causes, } \\
\text { such as laceration or sexual trauma. }\end{array}$ \\
\hline $\begin{array}{l}\text { Macdonald, P., Stanton, } \\
\text { M.E. }\end{array}$ & $\begin{array}{l}\text { USAID programme for the } \\
\text { Prevention And Treatment of Vaginal } \\
\text { Fistula } \\
\text { US Agency for International } \\
\text { Development, Washington, DC, USA. } \\
2007 . \\
\text { International Federation Of } \\
\text { Gynecology And Obstetric. } \\
\text { Published By Elsevier Ireland Ltd. }\end{array}$ & $\begin{array}{l}\text { The cornerstone of the USAID fistula program is to support and strengthen local capacity for fistula } \\
\text { repair. This includes support to upgrade facilities, enhance local surgical repair capability, allocate } \\
\text { equipment and supplies to operating rooms, implement quality improvement systems, and cover } \\
\text { the women's transportation costs to and from the treatment facilities. The programme also offers } \\
\text { training in clinical and counseling skills; transferring skills; and monitoring and evaluating the } \\
\text { program's effectiveness. As new fistula cases continually increase the backlog of untreated cases, } \\
\text { its efforts are also directed toward the prevention of fistula and the reintegration of treated } \\
\text { women into their communities. Furthermore, the program challenges the culture of sexual } \\
\text { violence against women that leads to traumatic gynecologic fistulas. }\end{array}$ \\
\hline $\begin{array}{l}\text { Mehta, M., } \\
\text { Pesso, L., } \\
\text { Ruminjo, J., } \\
\text { Sinclair, E., } \\
\text { Wegner, M.N. }\end{array}$ & $\begin{array}{l}\text { Improving community knowledge of } \\
\text { obstetric fistula prevention and } \\
\text { treatment. } \\
\text { International Journal of Gynecology } \\
\text { and Obstetrics (2007 99, S108 - S111 }\end{array}$ & $\begin{array}{l}\text { To determine what is known about community involvement in the prevention and treatment of } \\
\text { obstetric fistulas, the authors inquired into experiments carried out by EngenderHealth and } \\
\text { partners in } 15 \text { African and Asian countries. From raw data, gray literature, and personal } \\
\text { communications with those working fistulas in low - resource setting and they learned how to } \\
\text { engage the community. The communities are reached through communication campaigns with } \\
\text { messages about fistula prevention and treatment. Radio announcements, village theatre, print } \\
\text { media, and community education messages relayed in markets, schools, and community gatherings } \\
\text { are vital to reach the villagers. }\end{array}$ \\
\hline Mohammed, R.H. & $\begin{array}{l}\text { A community program for women's } \\
\text { health and development: } \\
\text { Implications for the long-term care } \\
\text { of women with fistulas. }\end{array}$ & $\begin{array}{l}\text { Documents the activities of the women's health and development project (FOWARD) in Nigeria. } \\
\text { The project was set up to improve the social, economic, and health status of women affected by } \\
\text { vesico-vaginal fistulas. The program takes a holistic approach not only by providing surgical repair } \\
\text { and rehabilitation, but also through the development skills that will help women improve their }\end{array}$ \\
\hline
\end{tabular}




\begin{tabular}{|c|c|c|}
\hline Authors & Title and Publication & Comments \\
\hline & $\begin{array}{l}\text { International Journal of Gynecology } \\
\text { and Obstetrics (2007) } 99 \text { S137-S142 }\end{array}$ & $\begin{array}{l}\text { physical and economic well-being. In addition, to prevent VVF in young women, the project } \\
\text { organizes campaigns to bring about a culture fostering the education and empowerment of } \\
\text { women. }\end{array}$ \\
\hline $\begin{array}{l}\text { Ramsey, K., } \\
\text { Tell, K., } \\
\text { Velez, A. }\end{array}$ & $\begin{array}{l}\text { The campaign to end fistula: What } \\
\text { have we learned? Findings of facility } \\
\text { and community needs assessments. } \\
\text { International Journal of Gynecology } \\
\text { and Obstetrics (2007) 99), S143-S150 }\end{array}$ & $\begin{array}{l}\text { A summary of findings of the fistula needs assessments that have been conducted through the } \\
\text { campaign to end fistula in } 25 \text { countries Africa and Asia to expand knowledge on the issue related to } \\
\text { on causes and impact, country capacity to manage the problem and clinical and programmatic } \\
\text { gaps. The recommendations have been used to spark action and implementation of national } \\
\text { programs to eliminate obstetric fistula throughout African and Asia. }\end{array}$ \\
\hline $\begin{array}{l}\text { Jones, Debra, } \\
\text { Brazier, E., } \\
\text { Ramsey, K. }\end{array}$ & $\begin{array}{l}\text { Living testimony: obstetric fistula } \\
\text { and inequities in maternal health. } \\
\text { UNFPA and FCI Inc (2007) }\end{array}$ & $\begin{array}{l}\text { To date, } 31 \text { country level needs assessments have been conducted in } 29 \text { countries and many } \\
\text { provide new insight into the social, cultural and economic aspects of obstetric fistula. This } \\
\text { publication aims to raise awareness about the underlying dimensions of maternal mortality and } \\
\text { morbidity by reviewing the findings of the } 31 \text { country-level assessments on obstetric fistula. Across } \\
\text { country assessments, the typical fistula patient was young, and lived in the rural area. Additionally, } \\
\text { obstetric fistula was observed among women who delivered four or more children. Many } \\
\text { adolescent girls and women living with fistula did not utilize health services because of their limited } \\
\text { decision-making power and attitudes and misconceptions about pregnancy and childbirth. } \\
\text { Furthermore, political insecurity and economic instability impeded transportation and access to } \\
\text { maternal health care services. Finally in most regions, where women lived with fistula, treatment } \\
\text { services were minimal or non-existent. }\end{array}$ \\
\hline \multicolumn{3}{|c|}{ Policy in countries south of the Sahara } \\
\hline Gebrekidan, A. & $\begin{array}{l}\text { National Fistula Assessment. } \\
\text { UNFPA and Ministry of Health, } \\
\text { Asmara, Eritrea. (2003). }\end{array}$ & $\begin{array}{l}\text { The study was conducted to assist the } \mathrm{MOH} \text { to: do a situation analysis for possible further } \\
\text { intervention; explore sources of funds to establish a fistula center for fistula management and care; } \\
\text { train and allocate health workers who are capable to provide EMOC at all health facilities; to } \\
\text { provide quality RH care and reduce maternal mortality and morbidity nationwide and use the data } \\
\text { collected to raise awareness and prevent fistula at the community and health facility levels. } \\
\text { Recommendations: Educate community on the causes of obstetric fistula; involve men in } \\
\text { reproductive health process; training and capacity building to improve RH care; strengthen IEC } \\
\text { programs at the community and health facility regularly; organize a fistula center and develop } \\
\text { proper records of women living with fistula at the national level. }\end{array}$ \\
\hline Johnson, K. & $\begin{array}{l}\text { Incontinence in Malawi: analysis of a } \\
\text { proxy measure of vaginal fistula in } \\
\text { national survey. }\end{array}$ & $\begin{array}{l}\text { Objective: to document the first effort to collect national lifetime prevalence data on vaginal } \\
\text { fistulas and discern the usefulness of the measure. } \\
\text { Results: the relationships between fistula symptoms and wealth and fistula symptoms and }\end{array}$ \\
\hline
\end{tabular}




\begin{tabular}{|c|c|c|}
\hline Authors & Title and Publication & Comments \\
\hline & $\begin{array}{l}\text { International Journal of Gynecology } \\
\text { and Obstetrics (2007) 99, S122- } \\
\text { S129 }\end{array}$ & $\begin{array}{l}\text { education were negative and monotonic. Rural women were } 40 \% \text { more likely than urban women to } \\
\text { report the symptoms, and those who had experienced a stillbirth were } 66 \% \text { more likely to report } \\
\text { the symptoms, and those who had experienced sexual violence were } 71 \% \text { more likely to report the } \\
\text { symptoms. A crude fistula rate of } 15.6 \text { per } 1000 \text { live births was found for Malawi. Conclusions: } \\
\text { survey methods may be used to capture the prevalence of vaginal fistula cases in a given country, } \\
\text { but further work is needed to improve the sensitivity and specificity of the questions asked. }\end{array}$ \\
\hline $\begin{array}{l}\text { Morhason-Bello, I.O., } \\
\text { Ojengbede, O.A., } \\
\text { Shittu, O. }\end{array}$ & $\begin{array}{l}\text { One-stage repair for combined } \\
\text { fistulas: Myth or reality? } \\
\text { International Journal of Gynecology } \\
\text { and Obstetrics (2007) 99, S90-593 }\end{array}$ & $\begin{array}{l}\text { The repair of combined vesico-vaginal fistulas (VVFs) and recto-vaginal (fistulas (RVFs) is } \\
\text { challenging to both surgeon and patient. Methods: twenty patients aged between } 16 \text { and } 38 \text { years } \\
\text { were recruited for multicenter study conducted from March } 2005 \text { to August } 2006 \text {. } \\
\text { Prolonged/obstructed labor was the cause of all fistulas. The RVFs measured between } 1 \text { and } 3 \mathrm{~cm} \text {, } \\
\text { they were low in } 70 \% \text { of cases, and one was associated with fourth-degree perineal tear. Bowel } \\
\text { preparation was performed in all patients prior to surgery. No patient underwent temporary } \\
\text { colostomy. } \\
\text { Results: both VVFs and VVFs were successfully closed in all patients, as evidenced by the emotional } \\
\text { challenges, and it accelerates restoration to health and social reintegration for women affected } \\
\text { with both VVFs and RVFs. }\end{array}$ \\
\hline $\begin{array}{l}\text { Ojengbede, O.A., } \\
\text { Shittu, O.S., } \\
\text { Wara, L.H.I. }\end{array}$ & $\begin{array}{l}\text { A review of postoperative care for } \\
\text { obstetric fistulas in Nigeria. } \\
\text { International Journal of Gynecology } \\
\text { and Obstetrics (2007) 99, S79-S84 }\end{array}$ & $\begin{array}{l}\text { Literature review on fistula in Nigeria to identify strategies and practices that if adopted, would } \\
\text { likely accelerate the pace of fistula repair and improve postoperative fistula care in the country. } \\
\text { Recommends that a comprehensive nationwide survey, a stronger political will and commitment of } \\
\text { resources, a systematic postoperative care and follow up, more fistula centers, and campaigns are } \\
\text { necessary. Technically, the involvement of all surgeons trained in fistula repair and an experience } \\
\text { based postoperative management protocol will relieve the disease burden carried by women living } \\
\text { with fistula. }\end{array}$ \\
\hline UNPFA & $\begin{array}{l}\text { Fistula in Brief. } \\
\text { Campaign to End Fistula. } 2006\end{array}$ & $\begin{array}{l}\text { Gives the definition, causes; medical and psychosocial consequences; prevention; prevalence and } \\
\text { treatment of obstetric fistula. A simple surgery can normally repair the injury, with success rates as } \\
\text { high as } 90 \text { per cent for experienced surgeons. The average cost of fistula treatment and post- } \\
\text { operative care is just US } \$ 300 \text {. Like maternal mortality, fistula is almost entirely preventable. But at } \\
\text { least } 2 \text { million women in Africa, Asia and the Arab region are living with the condition, with new } \\
\text { cases between } 50,000 \text { to } 100,000 \text { each year. } \\
\text { Obstetric fistula occurs disproportionately among impoverished girls and women, especially those } \\
\text { living far from medical services. Affecting the most powerless members of society, it touches on } \\
\text { nearly every aspect of UNFPA's mandate, including reproductive health and rights, gender equality, } \\
\text { poverty and adolescent reproductive health. }\end{array}$ \\
\hline Wall, L.L. & $\begin{array}{l}\text { Ethical issues in vesico-vaginal fistula } \\
\text { care and research. }\end{array}$ & $\begin{array}{l}\text { The plight of women in poor non-industrialized countries who have incurred catastrophic childbirth } \\
\text { injuries, such as vesico-vaginal and recto-vaginal fistulas, from prolonged obstructed labor is }\end{array}$ \\
\hline
\end{tabular}




\begin{tabular}{|c|c|c|}
\hline Authors & Title and Publication & Comments \\
\hline & $\begin{array}{l}\text { International Journal of Gynecology } \\
\text { and Obstetrics (2007) 99, S32-S39 }\end{array}$ & $\begin{array}{l}\text { receiving increased attention from the world medical community. While the good intentions that } \\
\text { have prompted this greater concern are not in doubt, intentions by themselves are insufficient } \\
\text { guarantees of ethical conduct in programs developed to repair these injuries. Clinical proposals put } \\
\text { forward to deal with the problem of fistula must undergo critical analysis to ensure that basic } \\
\text { ethical requirement is met. This article emphasizes the vulnerability to exploitation of women with } \\
\text { obstetric fistulas and reviews the basic principles of medical ethics relevant to fistula care. }\end{array}$ \\
\hline Wall, L.L. & $\begin{array}{l}\text { Where should obstetric vesico- } \\
\text { vaginal fistulas be repaired: at the } \\
\text { district general hospital or a } \\
\text { specialized fistula center? } \\
\text { International Journal of Gynecology } \\
\text { and Obstetrics (2007) 99, S28 - S31 }\end{array}$ & $\begin{array}{l}\text { Expanded surgical capacities are required to treat obstetric fistulas. Achieving a balance between } \\
\text { relative ease of access to services and use of the appropriate clinical setting is difficult. This article } \\
\text { asks, "are obstetric fistulas best repaired locally, at the district hospital where more women would } \\
\text { have greater access, or it is necessary to provide these services at a tertiary referral or fistula } \\
\text { center, where specialized surgical procedures can be conducted; each possibility has advantages } \\
\text { and disadvantages." } \\
\text { Recommendations: Three critical factors are necessary to provide safe and effective fistula repair } \\
\text { services; adequate, long-term funding to cover the costs of all aspects of the care; the presence of } \\
\text { a surgeon who is a "fistula champion" and adequate operating theatre time and supplies. Without } \\
\text { external funding, these prerequisites are almost impossible to meet at rural district hospitals. }\end{array}$ \\
\hline \multicolumn{3}{|c|}{ C Socio-cultural and community factors } \\
\hline $\begin{array}{l}\text { AbouZahr, Carla, } \\
\text { Wardlaw, Tessa }\end{array}$ & $\begin{array}{l}\text { Maternal mortality at the end of a } \\
\text { decade: signs of progress? } \\
\text { Bulletin of the World Health } \\
\text { Organization, } 2001,79(6)\end{array}$ & $\begin{array}{l}\text { This article examines recent trends in two indicators associated with maternal mortality: the } \\
\text { percentage of births assisted by a skilled health care worker and rates of caesarean delivery. } \\
\text { Globally, modest improvements in coverage of skilled care at delivery have occurred, with an } \\
\text { average annual increase of } 1.7 \% \text { over the period } 1989-99 \text {. Progress has been greatest in Asia, the } \\
\text { Middle East and North Africa, with annual increases of over } 2 \% \text {. In sub-Saharan Africa, on the other } \\
\text { hand, coverage has stagnated. In general, caesarean delivery rates were stable over the 1990s. } \\
\text { Countries where rates of caesarean deliveries were the lowest-and where the needs were } \\
\text { greatest-showed the least change. This analysis leads us to conclude that whereas there may be } \\
\text { grounds for optimism regarding trends in maternal mortality in parts of North Africa, Latin } \\
\text { America, Asia, and the Middle East, the situation in sub-Saharan Africa remains disquieting. }\end{array}$ \\
\hline $\begin{array}{l}\text { Braimoh, Suleiman, } \\
\text { Chiwuzie, Jasper, } \\
\text { Okolocha, Chike, } \\
\text { Olumeko, Patience, } \\
\text { Unuigbe, Jacob }\end{array}$ & $\begin{array}{l}\text { Socio - Cultural Factors In Maternal } \\
\text { Morbidity and Mortality: A Study Of } \\
\text { a Semi-Urban Community In } \\
\text { Southern Nigeria. } \\
\text { Epidemiol Community Health (1998); } \\
293-297\end{array}$ & $\begin{array}{l}\text { Study objective: To understand community based or socio- cultural factors that determine } \\
\text { maternal morbidity and mortality in a semi-urban setting. } \\
\text { Results: There is a fairly good knowledge of hemorrhage but this is circumscribed by attitudes, } \\
\text { practices, and situations that keep women away from or delay the decision to seek obstetric care. } \\
\text { Conclusion: For a fuller understanding of maternal morbidity and mortality, it is important to } \\
\text { consider factors outside the hospital and formal medical practices, and situations can be enhanced } \\
\text { through modeling on them. }\end{array}$ \\
\hline & National Safe Motherhood & The study was conducted to enable the $\mathrm{MOH}$ in Ethiopia to: strengthen and expand quality \\
\hline
\end{tabular}




\begin{tabular}{|c|c|c|}
\hline Authors & Title and Publication & Comments \\
\hline $\begin{array}{l}\text { Ethiopia Ministry of } \\
\text { Health }\end{array}$ & $\begin{array}{l}\text { Community Based Survey in Ethiopia } \\
\text { Edited by Rumbold and Warren } 2004 \\
\text { Funded by UNFPA }\end{array}$ & $\begin{array}{l}\text { community based MNH services; establish guidelines for the implementation of facility and } \\
\text { community level MNH activities; address quality, access and sustainability issues; strengthen } \\
\text { existing MNH programmes and develop programmes to promote and improve the overall health of } \\
\text { women and newborns. This was done by gathering data from communities distributed across all } \\
\text { the eleven regions in order to obtain a composite picture of community access to and perceptions } \\
\text { of MNH services. }\end{array}$ \\
\hline Gebrekidan, Abrehet & $\begin{array}{l}\text { National Fistula Needs Assessment in } \\
\text { Eritrea. MOH and UNFPA. December } \\
2003 .\end{array}$ & $\begin{array}{l}\text { The study was done to assess and document the current state of obstetric fistula in the six zones of } \\
\text { the country for further possible intervention (establish a national fistula center). } \\
\text { Recommendations: Continuous community health education about the causes, prevention, } \\
\text { medical and psychosocial effects of obstetric fistula. Male involvement in reproductive health } \\
\text { especially pregnancy and delivery related. . All health providers must be oriented to the problems } \\
\text { and early detection of high-risk mothers through appropriate supervisory support. Continuous in } \\
\text { service training to all health providers to provide basic emergency obstetric care and to make them } \\
\text { more responsive to the needs of the pregnant and laboring women. Increase delivery coverage by } \\
\text { skilled health personnel. Strengthen IEC programs at the community and HFs regularly. Organize a } \\
\text { fistula center. All women with urine/bowel incontinence need to be registered and appear in } \\
\text { monthly report of the HFs and in the HMIS reporting system. }\end{array}$ \\
\hline $\begin{array}{l}\text { Mwangi, A., } \\
\text { Warren, C. }\end{array}$ & $\begin{array}{l}\text { Taking Critical Services to the Home: } \\
\text { Scaling-up Home-based Maternal } \\
\text { and Postnatal Care, including Family } \\
\text { Planning, through Community } \\
\text { Midwifery in Kenya } \\
\text { Frontiers in Reproductive Health, } \\
\text { Population Council } 2008\end{array}$ & $\begin{array}{l}\text { An operations research carried out in four districts in Western Kenya to assist the } \mathrm{MOH} \text { to } \\
\text { institutionalize and scale up its community midwifery strategy and services, assess and describe the } \\
\text { feasibility of initiating the community midwifery package of MNH and FP services; and document } \\
\text { systematically and disseminate widely lessons learnt in sustaining and scaling up community } \\
\text { midwifery interventions. } \\
\text { Recommendations: Continued support to community midwifes by the government and other } \\
\text { professional bodies in skills and knowledge will ensure continued professional competency for } \\
\text { quality health care in the community; Financial support to the community midwifes either by } \\
\text { community members or the government to replenish supplies and allow them to offer services to a } \\
\text { greater range of clients; training business skills builds the midwifes capacity in running their } \\
\text { services to make them self-sustaining; strengthening and supporting the linkage between the } \\
\text { formal health sector and community midwifes enables the community midwifes reach and serve } \\
\text { poor populations not covered through the formal health sector. }\end{array}$ \\
\hline Rumbold, Tori & $\begin{array}{l}\text { Cultural beliefs and practices } \\
\text { influencing maternal and newborn } \\
\text { health in Western Province. } \\
\text { Population Council } 2006\end{array}$ & $\begin{array}{l}\text { Following the Safe Mother Demonstration Project in Western Province Kenya (2000 -2004), it was } \\
\text { noted that the facility delivery rate remained stagnant at around } 29 \% \text {. The findings of this report } \\
\text { illustrate the influence of environmental and cultural factors on health related beliefs and } \\
\text { practices. For instance beliefs regarding the spiritual source of certain obstetric complications } \\
\text { contribute to harmful delays in seeking appropriate care. The report emphasizes the need to }\end{array}$ \\
\hline
\end{tabular}




\begin{tabular}{|l|l|l|l|}
\hline & Authors & Title and Publication & Comments \\
\hline & & $\begin{array}{l}\text { improve the knowledge and awareness of all community members - all genders, ages and status in } \\
\text { order to dispel myths and misconceptions that contribute to the first delay and to low utilization of } \\
\text { health services. }\end{array}$ \\
\hline $\begin{array}{l}\text { Rumbold, Tori, } \\
\text { Warren, C. }\end{array}$ & $\begin{array}{l}\text { A Review of the Community } \\
\text { Midwifery Pilot Initiative in Western } \\
\text { Province, Kenya }\end{array}$ & $\begin{array}{l}\text { The Community Midwifery model was piloted in Western Province in 2005 in an attempt to address } \\
\text { low levels of skilled attendance at birth; through empowerment of unemployed or retired } \\
\text { midwives already living in the community to assist women during pregnancy, childbirth and post } \\
\text { partum period in their homes, manage minor complications, and facilitate referral. } \\
\text { Findings: The sustainability of the community midwifery initiative is threatened by the lack of } \\
\text { financial incentives; there exists an equivocal support for the community midwifery initiative } \\
\text { among stakeholders but awareness and sensitization efforts need to be improved; the mandates of } \\
\text { all health providers, both in the community and facility-based need to be reviewed and clarified; } \\
\text { systematic support for the community midwives requires revision and improvement; referral } \\
\text { systems are compromised by poor transport and communication links, and lack of birth } \\
\text { preparedness and community mobilization and birth preparedness need to be key elements of the } \\
\text { improved community midwifery strategy. }\end{array}$ \\
\hline
\end{tabular}


Appendix 4: Hospital capacity/preparedness to repair obstetric fistula in the four districts

\begin{tabular}{|c|c|c|c|c|c|c|c|}
\hline $\begin{array}{l}\text { Health } \\
\text { Facility }\end{array}$ & $\begin{array}{l}\text { Repair } \\
\text { OF }\end{array}$ & $\begin{array}{l}\text { Physician } \\
\text { Trained }\end{array}$ & $\begin{array}{l}\text { Equipment } \\
\text { Available }\end{array}$ & $\begin{array}{l}\text { OF Repair } \\
\text { Fees }\end{array}$ & $\begin{array}{l}\text { Specific Problems of } \\
\text { OF Repair }\end{array}$ & $\begin{array}{l}\text { Recommendation for OF } \\
\text { Prevention }\end{array}$ & $\begin{array}{l}\text { Recommendations for OF } \\
\text { Repair }\end{array}$ \\
\hline $\begin{array}{l}\text { Kilifi } \\
\text { Hospital }\end{array}$ & $\begin{array}{l}\text { Do not } \\
\text { repair }\end{array}$ & Yes & $\begin{array}{l}\text { No equipment } \\
\text { available }\end{array}$ & - & $\begin{array}{l}\text { OF repairs are only } \\
\text { done occasionally so } \\
\text { cannot say whether } \\
\text { there are problems. }\end{array}$ & $\begin{array}{l}\text { Strengthening delivery by skilled } \\
\text { personnel. } \\
\text { Training community midwives. } \\
\text { Community mobilization } \\
\text { through dissemination of the } \\
\text { most important information and } \\
\text { communication on behavior } \\
\text { change. } \\
\text { Training teams to repair women } \\
\text { living with OF. }\end{array}$ & $\begin{array}{l}\text { Decentralization of the } \\
\text { repair of obstetric fistula to } \\
\text { district Hospital level. }\end{array}$ \\
\hline $\begin{array}{l}\text { Mwingi } \\
\text { Hospital }\end{array}$ & Repair & Yes & $\begin{array}{l}\text { All except } \\
\text { thorax } \\
\text { scissors, } \\
\text { theatre table, } \\
\text { aneurism } \\
\text { needle, } \\
\text { sutures, spinal } \\
\text { anesthesia }\end{array}$ & Ksh 5,000 & $\begin{array}{l}\text { Theatre table since it } \\
\text { is fixed cannot be } \\
\text { manipulated. } \\
\text { Lack of complete VVF } \\
\text { set. } \\
\text { Lack of community } \\
\text { awareness about OF } \\
\text { repairs. } \\
\text { Poor community } \\
\text { health seeking } \\
\text { behavior even free } \\
\text { treatment. } \\
\text { Stigma and isolation } \\
\text { of OF clients. } \\
\text { Community believes } \\
\text { OF can't be repaired. }\end{array}$ & $\begin{array}{l}\text { Community ambulance can be } \\
\text { stationed in the periphery } \\
\text { health facilities other than at } \\
\text { the district hospital for quicker } \\
\text { referral. } \\
\text { Upgrade periphery health } \\
\text { facilities. } \\
\text { Emphasis on Partograph } \\
\text { monitoring. } \\
\text { Increase midwife-client ratio in } \\
\text { the ward. } \\
\text { Improve infrastructure and } \\
\text { transport which is the main } \\
\text { cause of delay in referring } \\
\text { patients. }\end{array}$ & $\begin{array}{l}\text { Early repair. } \\
\text { Train more staff on OF } \\
\text { repair. } \\
\text { Complete waiver system for } \\
\text { OF clients. } \\
\text { Provision of complete VVF } \\
\text { sets/equipment, e.g. mobile } \\
\text { adjustable mobile theater } \\
\text { tables. } \\
\text { Improve infrastructure and } \\
\text { referral system. }\end{array}$ \\
\hline $\begin{array}{l}\text { Nyahururu } \\
\text { Hospital }\end{array}$ & Repair & Yes & $\begin{array}{l}\text { All equipment } \\
\text { available }\end{array}$ & Ksh 10,000 & $\begin{array}{l}\text { Have not had a skilled } \\
\text { person till } 3 \text { months } \\
\text { ago. } \\
\text { Patients are poor and } \\
\text { have financial } \\
\text { problems. } \\
\text { Some women delay to }\end{array}$ & $\begin{array}{l}\text { Prompt action when obstructed } \\
\text { labor is diagnosed. } \\
\text { Need to train more CMs from } \\
\text { other districts to take care of } \\
\text { mothers before they } \\
\text { complicate, e.g. Laikipia District. } \\
\text { Improve hospital charges that }\end{array}$ & $\begin{array}{l}\text { Early management } \\
\text { Checking the referral } \\
\text { system process, so as to } \\
\text { ensure mothers with VVF } \\
\text { are referred straight to a } \\
\text { facility that repairs rather } \\
\text { than having to pass through }\end{array}$ \\
\hline
\end{tabular}




\begin{tabular}{|c|c|c|c|c|c|c|c|}
\hline $\begin{array}{l}\text { Health } \\
\text { Facility }\end{array}$ & $\begin{array}{l}\text { Repair } \\
\text { OF }\end{array}$ & $\begin{array}{l}\text { Physician } \\
\text { Trained }\end{array}$ & $\begin{array}{l}\text { Equipment } \\
\text { Available }\end{array}$ & $\begin{array}{l}\text { OF Repair } \\
\text { Fees }\end{array}$ & $\begin{array}{l}\text { Specific Problems of } \\
\text { OF Repair }\end{array}$ & $\begin{array}{l}\text { Recommendation for OF } \\
\text { Prevention }\end{array}$ & $\begin{array}{l}\text { Recommendations for OF } \\
\text { Repair }\end{array}$ \\
\hline & & & & & $\begin{array}{l}\text { get to hospital and the } \\
\text { fistula may } \\
\text { complicate. }\end{array}$ & $\begin{array}{l}\text { put mothers off from going to } \\
\text { hospital for delivery. } \\
\text { Health workers co-ordinate with } \\
\text { community leaders to educate } \\
\text { the mothers on importance of } \\
\text { ANC attendance and hospital } \\
\text { delivery. } \\
\text { Refresh courses for doctors, } \\
\text { midwives and interns on } \\
\text { obstructed labour. }\end{array}$ & $\begin{array}{l}\text { all levels. } \\
\text { Every gynecologist to be } \\
\text { trained on VVF repair. }\end{array}$ \\
\hline $\begin{array}{l}\text { Ol Kalou } \\
\text { Hospital }\end{array}$ & $\begin{array}{l}\text { Do not } \\
\text { repair }\end{array}$ & Not trained & $\begin{array}{l}\text { Have all } \\
\text { equipment } \\
\text { except } \\
\text { Aurvard } \\
\text { speculum }\end{array}$ & Ksh 15,000 & $\begin{array}{l}\text { Equipment } \\
\text { Skilled staff }\end{array}$ & $\begin{array}{l}\text { Health education to mothers on } \\
\text { seeking medical attention } \\
\text { immediately. } \\
\text { Train more community } \\
\text { midwives to ease the referral of } \\
\text { mothers. } \\
\text { Road infrastructure so that } \\
\text { more come on time. } \\
\text { Provision of delivery kits and } \\
\text { coaches to the level } 2 \text {. } \\
\text { Discourage the community on } \\
\text { FGM } \\
\text { Proper management of labor. } \\
\text { Good nutrition to prevent } \\
\text { contracted pelvis } \\
\text { Youth friendly meeting. }\end{array}$ & $\begin{array}{l}\text { Improve infection } \\
\text { prevention to avoid } \\
\text { breakage and prolonged } \\
\text { hospital stay. } \\
\text { All patients with prolonged } \\
\text { labor to have a catheter. } \\
\text { Proper psychological and } \\
\text { counseling care. } \\
\text { Provision of equipment \& } \\
\text { supplies. } \\
\text { Training staff in many } \\
\text { facilities. } \\
\text { Future pregnancies to be } \\
\text { delivered by C/S. } \\
\text { Early repair to avoid } \\
\text { psychological trauma. }\end{array}$ \\
\hline $\begin{array}{l}\text { Taveta } \\
\text { Hospital }\end{array}$ & $\begin{array}{l}\text { Do not } \\
\text { repair }\end{array}$ & Not trained & $\begin{array}{l}\text { All equipment } \\
\text { available }\end{array}$ & Ksh 5,000 & $\begin{array}{l}\text { Lack of qualified } \\
\text { personnel to do the } \\
\text { repairs. } \\
\text { Very few clients-- very } \\
\text { few people have got } \\
\text { obstetric fistula. }\end{array}$ & $\begin{array}{l}\text { Ensure more deliveries in the } \\
\text { hospital. } \\
\text { Proper monitoring of labor using } \\
\text { partograph. } \\
\text { Early intervention in poor } \\
\text { progressing labor. }\end{array}$ & $\begin{array}{l}\text { Increased training of } \\
\text { personnel. } \\
\text { Increased emphasis on the } \\
\text { prevention. }\end{array}$ \\
\hline $\begin{array}{l}\text { Voi } \\
\text { Hospital }\end{array}$ & $\begin{array}{l}\text { Do not } \\
\text { repair }\end{array}$ & Yes & $\begin{array}{l}\text { No equipment } \\
\text { available }\end{array}$ & Ksh 7,000 & $\begin{array}{l}\text { All of equipment. } \\
\text { Demand for the } \\
\text { service is very low due }\end{array}$ & $\begin{array}{l}\text { Create awareness during ANC } \\
\text { and need for skilled care at } \\
\text { birth. }\end{array}$ & $\begin{array}{l}\text { All labor ward staff (MWs } \\
\text { and Drs) must be taught } \\
\text { about early management of }\end{array}$ \\
\hline
\end{tabular}




\begin{tabular}{|c|c|c|c|c|c|c|c|}
\hline $\begin{array}{l}\text { Health } \\
\text { Facility }\end{array}$ & $\begin{array}{l}\text { Repair } \\
\text { OF }\end{array}$ & $\begin{array}{l}\text { Physician } \\
\text { Trained }\end{array}$ & $\begin{array}{l}\text { Equipment } \\
\text { Available }\end{array}$ & $\begin{array}{l}\text { OF Repair } \\
\text { Fees }\end{array}$ & $\begin{array}{l}\text { Specific Problems of } \\
\text { OF Repair }\end{array}$ & $\begin{array}{l}\text { Recommendation for OF } \\
\text { Prevention }\end{array}$ & $\begin{array}{l}\text { Recommendations for OF } \\
\text { Repair }\end{array}$ \\
\hline & & & & & to low awareness. & $\begin{array}{l}\text { Partographs to be used to } \\
\text { detect prolonged obstructed } \\
\text { labor early } \\
\text { Training of staff on prevention } \\
\text { of fistula in patients with } \\
\text { obstructed labor. } \\
\text { Empowering communities and } \\
\text { women through education. } \\
\text { Improve referral systems from } \\
\text { dispensaries and health centers } \\
\text { to hospitals. }\end{array}$ & $\begin{array}{l}\text { VVF. } \\
\text { Have dedicated centers to } \\
\text { manage fistulas to build skill } \\
\text { development, research \& } \\
\text { total care of the patients } \\
\text { including physiotherapy, } \\
\text { psychotherapy and } \\
\text { rehabilitation. }\end{array}$ \\
\hline $\begin{array}{l}\text { Wesu } \\
\text { Hospital }\end{array}$ & $\begin{array}{l}\text { Do not } \\
\text { repair }\end{array}$ & Not trained & $\begin{array}{l}\text { All available } \\
\text { except -Sims } \\
\text { speculum and } \\
\text { Methylene } \\
\text { blue }\end{array}$ & $\begin{array}{l}\text { Under GA - } \\
\text { Ksh. 2,000 }\end{array}$ & $\begin{array}{l}\text { Lack of personnel } \\
\text { trained in fistula } \\
\text { repairs. } \\
\text { Lack of adequate } \\
\text { equipment. } \\
\text { Lack of mobilization } \\
\text { and sensitization of } \\
\text { community members } \\
\text { on the condition in } \\
\text { cases of home } \\
\text { deliveries. }\end{array}$ & $\begin{array}{l}\text { Encouraging more mothers to } \\
\text { be delivered by trained/skilled } \\
\text { midwives and doctors. } \\
\text { Health education on safe } \\
\text { motherhood. }\end{array}$ & $\begin{array}{l}\text { Prevention is cheaper than } \\
\text { cure. } \\
\text { Train more personnel on } \\
\text { repairs/management of } \\
\text { fistulas to make services } \\
\text { more accessible. }\end{array}$ \\
\hline
\end{tabular}

